UNIVERSIDADE DE SÃO PAULO

FACULDADE DE FILOSOFIA, LETRAS E CIÊNCIAS HUMANAS DEPARTAMENTO DE LETRAS CLÁSSICAS E VERNÁCULAS

PROGRAMA DE PÓS-GRADUAÇÃO EM FILOLOGIA E LÍNGUA

PORTUGUESA

LUCIANA PISSOLATO DE OLIVEIRA

\title{
A Terminologia da Genética Molecular: aspectos morfológicos e semânticos
}

São Paulo 


\section{LUCIANA PISSOLATO DE OLIVEIRA}

\section{A Terminologia da Genética Molecular: aspectos morfológicos e semânticos}

Dissertação apresentada à Faculdade de Filosofia, Letras e Ciências Humanas da Universidade de São Paulo para obtenção do título de Mestre em Filologia e Língua Portuguesa.

Orientadora: Prof. $^{\text {a }}$ Dr. $^{\text {a }}$ Ieda Maria Alves 


\section{FOLHA DE APROVAÇÃO}

Luciana Pissolato de Oliveira

A Terminologia da Genética Molecular: aspectos morfológicos e semânticos

Dissertação apresentada à Faculdade de Filosofia, Letras e Ciências Humanas da Universidade de São Paulo para obtenção do título de Mestre em Filologia e Língua Portuguesa.

Orientadora: Prof. ${ }^{\mathrm{a}}$ Dr. ${ }^{\mathrm{a}}$ Ieda Maria Alves

Aprovado em:

\section{Banca Examinadora}

Prof. Dr.

Instituição: Assinatura:

Prof. Dr.

Instituição: Assinatura:

Prof. Dr.

Instituição: Assinatura: 
Chega mais perto e contempla as palavras cada uma tem mil faces secretas sob a face neutra e te pergunta, sem interesse pela resposta pobre ou terrivel, que lhe deres: Trouxeste a chave?

DRUMMOND 


\section{DEDICATÓRIA}

À minha mãe, fonte de luz, paz e equilíbrio em todas as horas.

E a Deus, por cuidar de cada passo de minha caminhada. 


\section{AGRADECIMENTOS}

À minha mãe, pelo amor incondicional dedicado, além do grande incentivo nesta etapa de minha vida, sem o qual não teria sido possível a realização de meus estudos;

À Prof. ${ }^{\text {a Dr. }}$ ' Ieda Maria Alves, pela confiança, amizade e orientação durante todo o período;

À Prof. ${ }^{a}$ Dr. ${ }^{a}$ Gladis Maria de Barcellos Almeida, que me apresentou a Terminologia ainda na graduação, fazendo-me apaixonar pelos estudos e seguir carreira acadêmica, além da grande amizade, carinho e apoio, sempre;

Ao Prof. Dr. Francis Henrik Aubert e à Prof. ${ }^{a}$ Dr. ${ }^{a}$ Stella Esther Ortweiler Tagnin, pelas valiosas contribuições em banca de qualificação;

Ao Murilo Fatore de Arruda, pela cumplicidade e incentivo não só na realização deste trabalho, mas em tantas outras etapas de minha vida - além do apoio computacional na confecção de gráficos, tabelas, etc.;

À Sônia Buzato, por tornar a minha estadia em São Paulo possível e muito mais saborosa;

A todos os integrantes e ex-integrantes do grupo TermNeo, pela amizade e apoio na realização de cada etapa do trabalho;

À Fundação de Amparo à Pesquisa do Estado de São Paulo, pelo auxílio financeiro desta pesquisa, por meio de concessão de Bolsa de Mestrado;

E a todos os amigos e professores que, de uma forma ou de outra, contribuíram para a realização deste trabalho. 


\section{RESUMO}

OLIVEIRA, Luciana Pissolato. A Terminologia da Genética Molecular: aspectos morfológicos e semânticos. 2007. Dissertação (mestrado em Filologia e Língua Portuguesa). Faculdade de Filosofia, Letras e Ciências Humanas, Universidade de São Paulo, São Paulo, 2007.

Tendo em vista que as unidades de conhecimento especializado (UCEs) formam parte de um universo dinâmico, no panorama das inovações científico-tecnológicas, e que são fundamentais para a comunicação especializada, o presente trabalho, de viés lingüístico/comunicativo, tem por objetivo a sistematização, organização e estruturação do vocabulário da Genética Molecular. Para o empreendimento de tal tarefa, foram necessárias as seguintes etapas: elaboração de um corpus de pesquisa, formado por materiais autênticos que refletissem a área com maior correção; extração das unidades terminológicas representativas do domínio, baseada em critérios lingüísticos, pragmáticos e tipográficos como: caráter morfológico (com significado especializado no campo de conhecimento), condicionamentos sintagmáticos (coocorrência e comutação), grau de coesão e fixação sintática, proximidade de glosas explicativas, grau de lexicalização do termo, relação unívoca com o conceito especializado que designam (monossemia), artifícios tipográficos, análise contextual, seleção dos tipos de documentação adequados e também verificação das particularidades estilísticas dos diferentes níveis de linguagem; análise da constituição morfossintática das unidades elencadas, por meio da investigação de seus formantes e de suas características sintáticas, bem como de seu funcionamento em contexto, exame que apresentou características bastante interessantes - prefixos (bio-) e sufixos (-oma) caracterizando a área, presença marcante de formantes de língua geral (-agem, -ção, mento) na nomeação de métodos e técnicas de trabalho, predominância de composições sintagmáticas (com 69\% das formações) e preponderância de formantes greco-latinos nas derivações e composições cultas; e, finalmente, a elaboração de uma estrutura de conceitos que evidenciasse as relações de significação que se estabelecem entre os conceitos da área, trabalho para o qual em muito contribuiu o conhecimento dos formantes das unidades terminológicas, já que os mesmos podem traduzir-se em pistas para a adequada alocação de um termo em determinado campo semântico. Por fim, este trabalho pretende expandir-se, $a$ posteriori, em forma de obra de referência para alunos e pesquisadores da Genética 
Molecular, cooperando com a ciência em sua aprendizagem e divulgação.

Palavras-chave: morfologia; estruturação semântica; Genética Molecular; método em Terminologia. 


\section{ASTRACT}

OLIVEIRA, Luciana Pissolato. The Terminology of the Molecular Genetics: morphologic and semantic aspects. 2007. Master Dissertation. Faculdade de Filosofia, Letras e Ciências Humanas, Universidade de São Paulo, São Paulo, 2007.

Taking into consideration that the units of specialized knowledge take part of a dynamic universe, in the scenery of the scientific innovations, and that they are basic for the specialized communication, the present work, in the fields of communicative/linguistic, has as main objective the systematization, organization and structuration of the vocabulary of the Molecular Genetics. To undertake such task, the following stages were necessary: elaboration of a corpus of research, formed by authentic material that reflected the area with larger correction; removal of the representative terminological units of the domain, based on linguistic, pragmatic and typographical criteria as: morphologic character (with specialized meaning inside the knowledge field), syntactic conditioning (coherence and the commutation), degree of cohesion and syntactic fixation of the terms, proximity of explanatory comments, degree of lexicalization of the term, univocal relation with the specialized concept that is assigned (monosomy), typographical artifices, contextual analysis, election of adequate types of documentation and also verification of precise statistics of the different levels of language; analysis of the morphosyntactic constitution of the chosen units, through the inquiry of its content and its syntactic characteristics, as well as of its functioning in context, examination that presented interesting characteristics prefixes (bio-) and suffixes (- oma) characterizing the area, notable presence in the composition of general language (- agem, - ção, - mento) in the nomination of methods and techniques of work, predominance of syntagmatic compositions (with $69 \%$ of the formations) and superiority of composition Greek-Latin in the derivations and cultured compositions; and finally, the elaboration of a structure of concepts that could evidence the meaning relations that were established between the concepts of the area, work that contributed to the knowledge of the composition of the terminological units, since the same ones can be expressed in instructions for the correct allocation of a term in a specific semantic field. Finally, this work is intended to be extended, a posteriori, in form of 
reference for pupils and researchers of Molecular Genetics, cooperating with science in its learning and spreading.

Keyword: morphology; semantics structuration; Molecular Genetics; method in Terminology. 


\section{$\underline{\text { Lista de abreviaturas, siglas e símbolos }}$}

Adj. - adjetivo

Adv. - advérbio

S(composto) - substantivo composto

S(estrang.) - substantivo formado por estrangeirismo

S(sigla) - substantivo formado por sigla

S./s. - substantivo

s.f. - substantivo feminino

s.m. - substantivo masculino

SAdj. - sintagma adjetival

SAdj. (epônimo) - sintagma adjetival formado por eponímia

SAdj.(estrang.) - sintagma adjetival formado por estrangeirismo

SAdj.(sigla) - sintagma adjetival formado por sigla

SN - sintagma nominal

SP - sintagma preposicional

SP(epônimo) - sintagma preposicional formado por eponímia

SP (estrang.) - sintagma preposicional formado por estrangeirismo

SP (latim) - sintagma preposicional formado por termo latino

SP (sigla) - sintagma preposicional formado por sigla

SV - sintagma verbal

TCT - Teoria Comunicativa da Terminologia

TGT - Teoria Geral da Terminologia 


\section{Lista de Figuras, Gráficos e Tabelas}

Figura 1. Processos de formação de unidades terminológicas 28

Figura 2. Delimitação da área-objeto

Figura 3. Armazenamento de informações no FolioViews 4.2.

Figura 4. Processos de formação lexical

Figura 5. Relações conceptuais 60

Figura 6. Diagrama arbóreo 89

Figura 7. Diagrama hierárquico 90

Gráfico 1. Produtividade dos prefixos 45

Gráfico 2. Produtividade dos sufixos 48

Gráfico 3. Produtividade dos processos de formação de palavras 55

Tabela 1. How five principles of traditional Terminology have been criticised by several terminologists 


\section{$\underline{\text { Sumário }}$}

1. Introdução _ 15

1.1. Percurso acadêmico ___ 15

1.2. Justificativa

1.3. Organização da Dissertação

2. Perspectiva teórica __ 20

2.1. Percurso histórico da Terminologia 20

2.1.1. Teoria Geral da Terminologia - TGT _ 23

2.1.2. Da TGT à TCT: um percurso __ 25

2.1.3. Terminologia sócio-cognitiva ___ 31

2.2. Aplicações dos estudos terminológicos

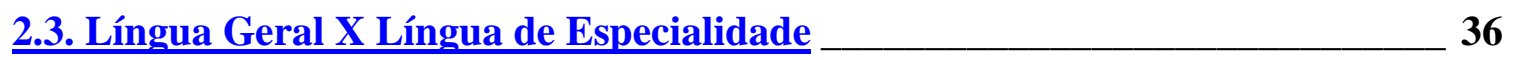

2.4. Termo X Palavra _ 37

2.4.1. As unidades de conhecimento especializado - UCEs __ 42

3. A pesquisa — 43

3.1. Identificação e seleção de termos: constituição do corpus de trabalho ___ 43

3.2. Processos de inovação lexical: uma análise baseada no corpus da Genética Molecular 52

3.2.1. As formações sintáticas _

3.2.1.1. Derivação — 54

3.2.1.1.1. Derivação prefixal _ 54

$\underline{3.2 .1 .1 .2 \text {. Derivação sufixal — }} 57$

3.2.1.2. Composição __ 60

3.2.1.3. Formação sintagmática ___ 62

3.2.1.4. Sigla e acronímia ___ 64

3.2.2. Empréstimo / Estrangeirismo ___ 64

3.2.3. Neologismo semântico ___ 65

3.2.4. Outros processos 66

3.2.4.1. Formação simples __ 66

3.2.4.2. Eponímia — 66

3.2.4.3. Derivação regressiva___ 66

3.3. Organização semântica do vocabulário da Genética Molecular ___ 68

3.3.1. Campo lexical, campo conceptual e campo semântico __ 68

3.3.2. As relações conceptuais _ 71

3.3.2.1. Relações hierárquicas _ 73

3.3.3. Importância da elaboração de estruturas conceptuais para um trabalho terminográfico 76

3.3.3.1. da escolha da nomenclatura __ 76 
3.3.3.2. do tratamento dos dados terminográficos

4. Análises 78

4.1. Descrição das formações da terminologia da Genética Molecular ___ 78

4.1.1. Derivação 79

4.1.1.1. Derivação prefixal__ 79

4.1.1.2. Derivação sufixal__ 80

4.1.2. Formação sintagmática ___ 81

4.1.2.1. $S+$ Adj.

4.1.2.2. $S+$ SAdj.

4.1.2.3. S(composto) + Adj.

4.1.2.4. S(composto) + Adj. + Adj.___ 87

4.1.2.5. S + Adj. + Adj.__ 87

4.1.2.6. S (sigla) + Adj.

4.1.2.7. S(sigla) + SAdj — 89

4.1.2.8. $S+S P$

4.1.2.9. $S+S P(S+S P)$

4.1.2.10. $S+S P(S+A d j$.

4.1.2.11. $S+S P(S+S P+A d j$.

4.1.2.12. $S+A d j .+S P$

4.1.2.13. $S+A d j+S P(S+S P)$

4.1.2.14. $S+A d j .+S P(S+A d j$.

4.1.2.15. $S+S P+(S+S P(S+A d j)$.

3.3.2.16. $S$ (composto) $+S P$

4.1.2.17. Outras estruturas _ 94

4.1.3. Composição — 94

4.2.3.1. base presa / base livre __ 94

4.1.3.2. base presa / base presa — 95

4.1.3.3. base livre / base livre___ 96

4.1.4. Sigla _ 96

4.1.5. Neologismo semântico __ _ 96

4.1.6. Estrangeirismo _ 97

4.1.6.1. do inglês — 97

4.1.6.1. do francês — 98

4.1.7. Outros processos menos produtivos __ 98

4.1.7.1. Formação simples __ 98

4.1.7.2. Eponímia — 99

4.1.7.3. Decalque — 99

4.1.7.4. Derivação regressiva___ 99

4.1.7.5. Redução __ 99

4.2. Estrutura conceitual dos termos da Genética Molecular _ 99

5. Considerações finais _ 122

6. Referências _ 126

6.1.Teorias lingüísticas __ 126

6.2. Obras especializadas ___ 126 


\section{Introdução}

O objetivo primeiro de um trabalho terminológico está centrado na facilitação da comunicação especializada, seja por meio da harmonização terminológica, da elaboração de materiais dicionarísticos, ou pelo estudo sistemático das unidades terminológicas, ponto de partida para a Terminologia.

A Terminologia vem, assim, através do estudo das linguagens de especialidade e de seu vocabulário, criar um meio de comunicação mais eficaz e preciso, que permita o intercâmbio tecnológico entre os diversos segmentos técnico-científicos, uma vez que é por meio dessas linguagens de especialidade que os profissionais das mais diversas áreas do conhecimento divulgam suas experiências e sua cientificidade que, por sua vez, são adquiridas por tantos outros.

Nesse sentido, a presente Dissertação pretende cooperar com a fixação da terminologia da Genética Molecular em Língua Portuguesa, haja vista ser essa uma área em acelerado desenvolvimento no país e no mundo. Esta cooperação baseia-se na sistematização de seu vocabulário, em sua organização e estruturação, como um pano de fundo visando à elaboração, a posteriori, de um manual de consulta para estudantes e especialistas da disciplina.

\subsection{Percurso acadêmico}

Meu contato com a pesquisa em Terminologia data de 2001, quando cursava o segundo ano de Letras na Universidade Federal de São Carlos - UFSCar. A pesquisa nessa área era desenvolvida pela Profa. Dra. Gladis Maria de Barcellos Almeida, professora do Departamento de Letras (DL), na mesma instituição.

Através de reuniões e de grupo de estudos e discussões ${ }^{1}$, iniciei minhas atividades nesta área, e um ano depois obtive a concessão de Bolsa Fapesp - IC pelo período de um ano e meio ${ }^{2}$. No grupo, desenvolvia pesquisa sobre definições terminológicas para um dicionário de Fisioterapia, além de estudar teorias relativas à Terminologia de modo geral.

\footnotetext{
${ }^{1}$ Grupo de Estudos e Pesquisas em Terminologia (GETerm), coordenado pela Profa. Dra. Gladis Maria de Barcellos Almeida.
} 
Dessa maneira, prossegui meus estudos na mesma área, ingressando no curso de pós-graduação na Universidade de São Paulo - USP, em fevereiro de 2005, sob orientação da Profa. Dra. Ieda Maria Alves, referência em estudos do léxico. Como tema de pesquisa foi escolhida a terminologia da Genética Molecular, mais precisamente a análise de sua constituição morfológica e semântica, o que também gerou subsídios para um dicionário da área. Cabe dizer que tal escolha deveu-se a necessidades de sistematização oriundas do próprio domínio, expressa por professores do Departamento de Genética e Evolução da Universidade Federal de São Carlos - UFSCar ${ }^{3}$.

Cursando disciplinas, na pós-graduação, pude aperfeiçoar e aprofundar meus conhecimentos na área: não só os relativos à Terminologia, mas também à Língua Portuguesa de um modo geral, uma vez que a morfologia (sobretudo), a semântica e a sintaxe contribuíram sobremaneira para minha formação acadêmica, bem como para o desenvolvimento da pesquisa. Além disso, o fato de ter participado do Programa de Aperfeiçoamento ao Ensino - $\mathrm{PAE}^{4}$ foi de suma importância no alargamento de meus conhecimentos. Também a participação em reuniões do grupo TermNeo ${ }^{5}$ e em congressos, além da realização do Curso de Postgrado Online de Introducción a la Terminologia, promovido pela Universitat Pompeu Fabra - Barcelona, foram de grande importância para a minha formação.

Este projeto de pesquisa contou com o financiamento da FAPESP (processo 04/12602-6).

\subsection{Justificativa}

\footnotetext{
${ }^{2}$ Processo no. 02/14191-8 / FAPESP, referente a março 2003/setembro2004.

${ }^{3}$ Dentre eles o Prof. Dr. Pedro Manoel Galetti Júnior, professor adjunto do Departamento de Genética e Evolução (http://www2.ufscar.br/interface_frames/index.php?link=http://www.ufscar.br/ dge) $\quad$ e expresidente da Sociedade Brasileira de Genética (SBG).

4 Trata-se das etapas Preparação Pedagógica e Estágio Supervisionado em Docência para as seguintes disciplinas: Morfologia do Português e Introdução ao Estudo da Língua Portuguesa I, ambas ministradas pela Profa. Dra. Ieda Maria Alves para o curso de graduação em Letras da Universidade de São Paulo, nos períodos $2^{\circ}$. semestre 2006 e $1^{\circ}$. semestre 2007 , respectivamente.

${ }^{5}$ Trata-se do grupo Observatório de Neologismos Científicos e Técnicos do Português Contemporâneo (Projeto TermNeo), liderado pela Profa. Dra. Ieda Maria Alves. Disponível em

$<$ http://www.fflch.usp.br/dlcv/neo/>
} 
Uma das razões que legitimam a relevância desta pesquisa está baseada em fatores político-econômicos, uma vez que a cooperação entre países é a palavra-chave do mundo globalizado. Um dos objetivos primordiais dessa cooperação é o intercâmbio técnicocientífico, que muito tem contribuído para os avanços em pesquisas de todos os ramos do conhecimento, mas, em especial para aqueles em que a aplicação de tecnologias de ponta e grandes investimentos financeiros sejam condição sine qua non para a produção e pesquisa científica - caso da pesquisa em Genética Molecular, que exige grandes centros laboratoriais de pesquisa e investimentos altíssimos em materiais de análise e manipulação.

A pesquisa nessa área, ainda que de origem bastante recente - meados da década de 40 -, vem se mostrando como o ramo mais promissor da Genética no sentido científicotecnológico. Responsável pelo estudo da estrutura, função e evolução do material genético, ela é protagonista dos avanços mais importantes e polêmicos na área: através da análise direta e manipulação do DNA, torna-se possível realizar modificações genéticas em seres vivos, produzir seres transgênicos (animais e vegetais), diagnosticar doenças genéticas tardias, realizar a terapia genética (modificação de células humanas), fazer o mapeamento de genes (Projeto Genoma), realizar exames de paternidade, etc.

Segundo Luís Mír, organizador editorial do livro Genômica ${ }^{6}$ :

A revolução técnica-científica da biotecnologia penetra, modifica, avança em todos os campos: saúde humana, clonagem terapêutica, novos medicamentos, terapias gênicas, alimentação terapêutica, alimentos geneticamente modificados de origem animal e vegetal, entre outros.

Porém, grande parte da literatura produzida na área, por ter seus estudos realizados principalmente em grandes laboratórios e centros de pesquisa norte-americanos (detentores de alta tecnologia para tal fim), está escrita em língua inglesa, o que muitas vezes tende a gerar confusões e equívocos durante a conversão/tradução para a língua portuguesa. Há também países de língua espanhola, mais precisamente México, Chile e Espanha, que estão qualificando suas pesquisas nesta área, investindo na construção de centros de pesquisas e de equipados laboratórios de análise.

\footnotetext{
${ }^{6}$ Genômica. Organização editorial Luís Mir. São Paulo: Atheneu, 2004.
} 
Em vista desses fatos, a Terminologia vem, por meio do estudo dessas linguagens de especialidade e de seu vocabulário, descrever, sistematizar e organizar o conhecimento especializado, uma vez que é por meio dessas linguagens que os profissionais divulgam seus conhecimentos e sua cientificidade, os quais, por sua vez, são adquiridos por tantos outros.

Com o intuito, então, de criar um meio de comunicação mais eficiente e preciso, e que permita o intercâmbio tecnológico entre os diversos segmentos de estudos em Genética Molecular brasileiros e grandes centros de pesquisa sediados no exterior, o presente trabalho objetiva sistematizar essa terminologia, gerando subsídios para a futura elaboração de um dicionário da referida área.

\subsection{Organização da Dissertação}

A presente Dissertação está organizada em 6 capítulos (descontando-se esta introdução): no capítulo 2, "Perspectiva teórica", é apresentado um breve percurso histórico sobre a Terminologia, apontando-se, já nessa ocasião, o viés teórico norteador deste trabalho.

Ainda no capítulo 2, são abordados especificamente alguns conceitos, muitas vezes difusos para a Terminologia - os conceitos de língua geral e língua de especialidade, o que implica em um delineamento dos conceitos termo, palavra e unidade de conhecimento especializado.

Em seguida, o capítulo 3, "A Pesquisa", apresenta o embasamento teórico do trabalho, permeado com a metodologia utilizada para tal fim. São tratadas as seguintes etapas: a identificação e a seleção dos termos elencados para a constituição do corpus de trabalho; os processos de formação de palavras, baseados no corpus de pesquisa, através de descrição teórica e estatística de cada processo em particular.

Ainda no capítulo 3, é tratada a organização semântica do vocabulário da Genética Molecular, passando pelos conceitos de campo conceptual, campo léxico e campo semântico, abordando a temática das relações de significação que se dão entre conceitos. 
O resultado dos estudos morfo-semânticos realizados é apresentado no capítulo 4, “Ánálises”, onde estão descritas as formações da terminologia da Genética molecular, além da exposição da estrutura conceptual elaborada para a área.

Para finalizar a Dissertação, um capítulo de conclusão (capítulo 5), onde se busca mostrar em que medida a morfologia e a semântica, necessárias para os objetivos primeiros desta pesquisa (descrição e sistematização da terminologia da Genética Molecular), são fundamentais para a realização de um trabalho terminológico, além de algumas considerações sobre o saber-fazer teórico-metodológico. 


\section{Perspectiva teórica}

A perspectiva teórica que norteia este trabalho é a Terminologia de viés lingüístico/comunicativo, uma vez que seu objetivo é a descrição do funcionamento in vivo dos termos que conformam a área da Genética Molecular, além de organizar e sistematizar essa terminologia.

Para tanto, faz-se pertinente uma revisão dos modelos teóricos adotados por essa disciplina para o tratamento de seu objeto, qual seja, as unidades terminológicas. No subitem 2.1, a seguir, é traçado um breve percurso da Terminologia, apontando as características mais relevantes de cada período e, conseqüentemente, as implicações da teoria eleita como base para o desenvolvimento desta pesquisa.

\subsection{Percurso histórico da Terminologia}

A terminologia não é um fenômeno recente. Com efeito, tão longe quanto se remonte na história do homem, desde que se manifesta a linguagem, nos encontramos em presença de línguas de especialidade, é assim que se encontra a terminologia dos filósofos gregos, a língua de negócios dos comerciantes cretas, os vocábulos especializados da arte militar, etc. (Rondeau ${ }^{7}, 1984$ apud KRIEGER; FINATTO, 2004 p. 24).

Neste capítulo, serão brevemente descritas as diferentes correntes teóricas que versam sobre a Terminologia, desde seus princípios, com Eugen Wüster, fundador da Teoria Geral da Terminologia (TGT) - de viés normativo -, passando pela Socioterminologia de François Gaudin e pela Teoria Comunicativa da Terminologia (TCT) de Maria Teresa Cabré - de viés lingüístico e comunicativo -, e chegando à Terminologia

\footnotetext{
${ }^{7}$ RONDEAU, G. Introduction à la terminologie. Québec: Gaëtan Morin, 1984.
} 
sócio-cognitiva, com Rita Temmerman, que se baseia em processos de categorização e cognição para explicar os fatos terminológicos.

Traçar um percurso histórico da disciplina se faz bastante interessante, e até pertinente, na medida em que podemos abrir caminhos a novas interpretações e buscar novas metodologias de trabalho, além de adquirirmos uma mais vasta compreensão dos fatos lingüísticos que permeiam nossa área de estudo. Com o avanço das ciências e das técnicas, novas maneiras de compreensão e divulgação científicas foram sendo requeridas, fato que influencia grandemente o trabalho terminológico, que visa o tratamento, para diferentes fins, dos termos das áreas científicas e técnicas.

Apesar de a prática terminológica ser remota, haja vista a enorme incidência de termos oriundos do latim e do grego ainda hoje, somente na segunda metade do século XX é que se aprimoraram os métodos de tratamento e análise dessas terminologias. Lembremos, com Krieger e Finnato (2004, p. 25), que

[...] o reconhecimento formal da existência de vocábulos específicos de determinadas áreas de conhecimento se dá no século XVII, período em que alguns dicionários clássicos da cultura européia incluíram a terminologia como uma entrada, definindo-a como uma matéria que se ocupa das denominações de conceitos próprios das ciências e das artes.

Já no século XVIII, com o trabalho de enciclopedistas, as terminologias passam a ser tratadas formalmente, bem como são estabelecidas nomenclaturas técnico-científicas utilizando-se do grego e latim, como as ciências taxionômicas da Botânica, Zoologia, Química, etc.

A partir de então, a internacionalização das ciências é ponto forte para um maior desenvolvimento da Terminologia, o que faz com que cientistas preocupem-se com a univocidade da comunicação, daí acarretando uma prática de viés normativo. Assim, são estabelecidos padrões denominativos e de formação de termos para âmbitos de especialidade distintos, geralmente com a utilização de radicais greco-latinos, o que suscita um processo de particularização/distanciamento das terminologias frente aos vocábulos da língua geral.

Contudo, o acelerado avanço da ciência e tecnologia requer denominações novas para novas descobertas e invenções científicas. E é justamente essa expansão do 
conhecimento a responsável pela alteração do saber-fazer terminológico, uma vez que a composição dos novos termos adquire características distintas das apresentadas até então. Segundo Krieger e Finatto (2004, p. 27):

O crescimento exponencial das unidades terminológicas é um fenômeno diretamente resultante do acelerado avanço da ciência e da tecnologia que requer novas denominações para as novas descobertas e invenções que se avolumam. A ampliação do conhecimento científico e tecnológico, uma das mais marcantes características do final do milênio, vem, portanto, afetar a composição das terminologias, sejam elas criações originais, sejam denominações já existentes que passam a ser redefinidas, integrando novos campos e horizontes de conhecimento.

Atualmente, não se pode dizer que haja fronteiras nítidas entre o léxico comum e o de especialidade, uma vez que ciência e tecnologia são a mola mestra da sociedade atual e, com ela, vem o surgimento de uma grande quantidade e variedade de termos, para justamente expressar esses novos conhecimentos. Assim, os termos têm circulação irrestrita, passando do âmbito acadêmico para a divulgação em geral, o que facilita o processo de banalização e variação de grau de especialidade dessas terminologias.

Propiciado também pelos avanços em técnicas computacionais, o trabalho do terminólogo pôde evoluir com maior precisão e rapidez, visto que a produção de bancos de dados terminológicos e softwares de tratamento e reconhecimento de terminologias encontra-se em um estágio bastante adiantado e vem gerando excelentes resultados de pesquisa.

Além disso, são criadas e consolidadas redes internacionais de cooperação em Terminologia, reunindo grupos com interesses variados sobre a matéria e fazendo, assim, com que haja maior troca de saberes teórico-metodológicos e práticos, o que contribui sobremaneira para o avanço da disciplina.

Por essa ordem de fatores, a Terminologia vem desenvolvendo um papel bastante importante no aprimoramento de suas técnicas, já que é de utilidade recorrente nos mais diversos âmbitos da sociedade: seja em ambiente acadêmico, por meio da troca de conhecimentos; seja na prática profissional das mais diversas áreas do saber, ou na comunicação em geral. 
Nos tópicos subseqüentes serão apresentadas as proposições das diferentes escolas de Terminologia, que abrangem desde a Teoria Geral da Terminologia, de caráter normativo, passando pela Socioterminologia e pela Teoria Comunicativa da Terminologia, de viés lingüístico, e culminando na Terminologia Sócio-cognitiva.

\subsubsection{Teoria Geral da Terminologia - TGT}

O contexto histórico no qual se insere e surge a Teoria Geral da Terminologia faz referência aos estudos filosóficos do Círculo de Viena ${ }^{8}$, cuja temática estava centrada na precisão da linguagem. Enquanto os filósofos partiam para o estudo das proposições lógicas e da estrutura proposicional das teorias, buscando uma língua universal que permitisse a interação humana sem qualquer limitação e deficiência - fato julgado natural na língua geral, Wüster encarregou-se, a partir da lógica conceptual clássica, de elaborar uma teoria e metodologia de desenvolvimento e inovação da Terminologia, a fim de contribuir para a desambigüização da comunicação especializada. Para tanto, elaborou uma teoria semiótica que versasse sobre os signos e os princípios pragmáticos para o tratamento da linguagem, o que hoje é amplamente discutido - já que as terminologias são constituídas também por signos não-lingüísticos.

O ponto inicial de seu trabalho é a elaboração de uma metodologia para a normalização da linguagem, sendo a base teórica uma conseqüência. Para o Autor, existe uma diferença de atitude em relação à evolução das línguas e, por isso, Wüster desvincula a teoria da Terminologia da língua geral, uma vez que a Terminologia deve poder controlar o desenvolvimento da língua, no sentido de poder prescrever os melhores usos e denominações para cada área de especialidade.

Wüster define a Terminologia como um campo multidisciplinar, uma disciplina autônoma composta pela lingüística, lógica, ontologia e informática. Seu trabalho está baseado em cinco princípios básicos:

a) a perspectiva de análise é onomasiológica;

b) os conceitos são estáticos e bem definidos em um sistema estrutural; 
c) os conceitos devem receber definição tradicional;

d) a relação entre termo e conceito é unívoca;

e) os termos e conceitos devem ser estudados sincronicamente.

Passemos a uma análise mais detalhada sobre cada ponto.

A perspectiva de trabalho é onomasiológica, ou seja, parte do conceito e não do termo, por uma razão bastante prática: os conceitos e as denominações pertencem a âmbitos diferentes, sendo que os primeiros pertencem a um universo extralingüístico e se relacionam semanticamente através de uma estrutura, que os reflete independentemente da denominação que venham adquirir. Para o Autor, o processo de conceptualização é estritamente mental, deixando a denominação relegada à arbitrariedade e não levando em conta o importante papel que desempenha a linguagem nestes processos.

O segundo princípio descarta a hipótese do estudo dos conceitos isoladamente, mas considera-os como dependentes de uma estrutura que os relacione semanticamente. De acordo com Felber (1987, p. 101), "Etant donné que les notions sont composées de caractères, elles ont des rapports directs avec d'autres notions qui ont les mêmes caractères dans leurs compréhensions".

Assim,

Un domaine (ou une sous-section de domaine) n'est accessible mentalment que si le champ notionnel est structuré, c'est-à-dire s'il constitue ce que l'on appelle un système de notions. Dans cet ensemble, chaque notion révèle ses rapports avec les autres notions. Lorsque l'on compare différentes notions entre elles, on peut trouver les types de rapports (...). (FELBER, 1987, p.101)

Desse modo, as relações lógicas que se estabelecem entre os conceitos somente são passíveis de ocorrerem por meio da estruturação desses conceitos, o que pressupõe uma definição bastante clara sobre as características que estes apresentam, além de seu caráter estático (ideal para a comunicação desambigüisada e eficiente) - o que é bastante criticado atualmente, já que muitos conceitos são difusos e evoluem com o progresso das ciências.

\footnotetext{
${ }^{8}$ Trata-se do grupo liderado pelo filósofo Rudolf Carnap, o Círculo de Viena, na década de 30.
} 
O terceiro princípio trata das definições terminológicas, que devem ser de três tipos: intensional - através da listagem das características do conceito em questão; extensional através da enumeração das espécies ou objetos pertencentes ao conceito, e partitiva através da descrição do conceito superordenado acrescido das características distintivas. Vale ressaltar que tais tipos de definições têm sempre em mente a localização desses conceitos em sua estrutura.

O quarto princípio, o da univocidade entre termo e conceito, estabelece que cada conceito é designado por um termo, e cada termo pode referir-se a somente um conceito. Nada mais coerente sob a óptica da precisão da linguagem, princípio de normalização que regia a TGT. Sendo assim, a existência de polissemia e sinonímia em terminologia é totalmente descartada, já que a Terminologia, segundo Wüster ${ }^{9}$ (1984 apud TEMMERMAN, 2000 p. 11) "has the purpose to unify concepts and systems of concepts, to define concepts, to reduce homonymy, to eliminate synonymy, and to create if necessary new terms in line with terminological principles".

Finalmente, o quinto e último princípio versa sobre sincronia e terminologia. Os conceitos, como dito anteriormente, são estáticos e estabelecem relações fixas com outros conceitos da mesma área; assim, não parece assuntível para a TGT um estudo diacrônico ou mesmo a questão da evolução dos conceitos, advindos da evolução das ciências e das técnicas.

Desse modo, enquanto precursora da Terminologia, a TGT foi bastante funcional para seus objetivos e propósitos - a normalização das linguagens de especialidade; além de, por que não dizer, propiciar o advento de novas vertentes, provenientes de necessidades outras que não a normalizadora.

No tópico subseqüente são apontadas as insuficiências da TGT para os propósitos novos que foram surgindo, e uma nova corrente em Terminologia é apresentada.

\subsubsection{Da TGT à TCT: um percurso}

O ponto de partida para o questionamento da TGT foi o reducionismo de sua teoria e aplicação, bem como o princípio de uniformização que pretendia a mesma; fato que, a

\footnotetext{
${ }^{9}$ Referência não localizada.
} 
partir última década do século XX, vem sendo colocado à prova pelos mais distintos grupos de estudos em Terminologia.

Segundo Cabré (1999, p.69-70):

En lo que se refiere al primer punto, la teoría da muestras de reduccionismo en diferentes aspectos de sus concepciones y de sus prácticas: la concepción global de la unidad terminológica, la reducción de la unidad terminológica a su condición denominativa, el olvido de los aspectos sintácticos de las unidades terminológicas, la ignorancia de los aspectos comunicativos de los términos, o la insistencia en negar la variación formal y conceptual de los términos.

En relación al segundo aspecto, la teoría terminológica tradicional se basa en una pretendida homogeneidad que no confirman los datos empíricos relativos a los distintos ámbitos temáticos, las finalidades aplicadas, o la defensa de una única metodología.

Desse modo, a grande mudança de perspectiva, em Terminologia, resulta do fato de a unidade terminológica ser estudada sob o ponto de vista descritivo, e não prescritivamente, aos modos da TGT. Assim, "tratar de terminologia é tratar de questões das línguas e não de um constructo formal idealizado a serviço de uma comunicação restrita ao âmbito dos especialistas" (KRIEGER; FINATTO, 2004, p.34).

De acordo com Temmerman (2000, p.22-35), interessantes reações críticas à Escola de Viena vêm sendo feitas ao redor do mundo. Dentre elas, destacam-se alguns autores ${ }^{10}$, cujas inferências serão brevemente destacadas pela própria Autora, na tabela abaixo:

\footnotetext{
${ }^{10}$ Trata-se dos autores: Juan C. Sager, Peter Weinssenhofer, Britta Zawada e Piet Swanepoel, Maria Teresa Cabré, Ingrid Meyer, Jean-Claude Boulanger e François Gaudin (representantes da Socioterminologia) e Kyo Kageura.
} 


\begin{tabular}{|c|c|c|c|c|}
\hline Principle 1 & Principle 2 & Principle 3 & Principle 4 & Principle 5 \\
\hline the concept is central & concepts are clear-cut & intensional definition & monosemy & synchrony \\
\hline
\end{tabular}

\begin{tabular}{|c|c|c|c|c|c|}
\hline Sager & $\begin{array}{l}\text { naming approach replaced by } \\
\text { analysis of } t \text {. in a ling. context }\end{array}$ & $\begin{array}{l}\text { complex relationship/ multi- } \\
\text { dimensionality }\end{array}$ & $\begin{array}{c}\text { non specialists need } \\
\text { encyclopedic information }\end{array}$ & monosemy is rare & $\begin{array}{l}\text { term-formation is a process in } \\
\text { time }\end{array}$ \\
\hline Weissenhofer & $\begin{array}{l}\text { category approach instead of } \\
\text { concept approach }\end{array}$ & $\begin{array}{l}\text { categories have prototype str./ } \\
\text { inferential features/subject } \\
\text { fields on a scale from high to } \\
\text { low requirements of } \\
\text { definiteness }\end{array}$ & & \multirow[t]{2}{*}{$\begin{array}{l}\text { depending on the nature of the } \\
\text { subject field the requirements } \\
\text { for unambiguous t. may vary }\end{array}$} & \\
\hline $\begin{array}{l}\text { Zawada \& } \\
\text { Swanepoel }\end{array}$ & $\begin{array}{l}\text { classical concept theory is } \\
\text { inadequate to account for the } \\
\text { conceptual structure of the } \\
\text { natural and pure sciences }\end{array}$ & & $\begin{array}{c}\text { defining features of mineral } \\
\text { species are typically attributes } \\
\text { of prototype } \\
\text { categories/def:scalar } \\
\text { characteristics }\end{array}$ & & \\
\hline Cabré & & $\begin{array}{l}\text { the reality of special subjects:a } \\
\text { multifaceted configuration of } \\
\text { many concepts: it can be } \\
\text { studied from different } \\
\text { perspectives }\end{array}$ & & $\begin{array}{l}\text { aim of absolute uniformity of } \\
\text { scientific term is artificial } \\
\text { process unlikely to achieve its } \\
\text { goal }\end{array}$ & $\begin{array}{l}\text { the world technical and } \\
\text { scientific concepts to which } \\
\text { specialised terms refer are } \\
\text { permanently dynamic }\end{array}$ \\
\hline Meyer & & $\begin{array}{l}\text { multi-dimensionality arises } \\
\text { when a concept type can be } \\
\text { subclassified in more then one } \\
\text { way/any partitioning of reality is } \\
\text { arbitrary }\end{array}$ & $\begin{array}{l}\text { intensional definition only } \\
\text { enables specialists to object as } \\
\text { an exemple of a } \\
\text { category/importance of } \\
\text { encyclop. And lexical semantic } \\
\text { information }\end{array}$ & $\begin{array}{l}\text { dilema:T. can optimise and } \\
\text { promote unambiguous } \\
\text { comunication, or T. can } \\
\text { concentrate on diversity, } \\
\text { creativity and imagination in } \\
\text { scientific research }\end{array}$ & \\
\hline Socioterminology & $\begin{array}{l}\text { real language usage should be } \\
\text { studied }\end{array}$ & $\begin{array}{l}\text { clear-cut fields or domains do } \\
\text { not exist }\end{array}$ & & $\begin{array}{l}\text { polysemy and synonymy } \\
\text { should be studied }\end{array}$ & $\begin{array}{c}\text { diachronic study of } \\
\text { conceptualisation and naming }\end{array}$ \\
\hline Kargeura & $\begin{array}{l}\text { replaces 'concept' by 'meaning' } \\
\text { and studies parole instead of } \\
\text { langue }\end{array}$ & $\begin{array}{l}\text { strict delimitations successful } \\
\text { for unambiguous } \\
\text { communication in some fields }\end{array}$ & & & \\
\hline
\end{tabular}

Tabela 1: How five principles of traditional Terminology have been criticised by several terminologists (TEMMERMAN, 2000, p. 35-36)

Dentre os que se dirigem ao novo paradigma, daremos destaque ao grupo francês liderado por François Gaudin, com vistas à Socioterminologia, e ao grupo espanhol liderado por Maria Teresa Cabré, que propõe a Teoria Comunicativa da Terminologia, doravante TCT.

François Gaudin (1993, p.216), em sua tese de doutorado publicada em livro Pour une socioterminologie - des problèmes sémantiques aux pratiques institutionneles, declara: 


\begin{abstract}
C'est que la socioterminologie, pour peu qu'elle veuille dépasser les limites d'une terminologie 'greffière', doit replacer la genèse des termes, leur réception, leur acceptation mais aussi les causes de leur échec et les raisons de leur succès, au sein des pratiques langagières et sociales concrètes des hommes qui les emploient. Ces pratiques sont essentiellement celles qui s'exercent dans des sphères d'activité. C'est pourquoi la socioterminologie devait rencontrer les réflexions sur les liens qui se nouent entre travail et langage.
\end{abstract}

Preocupado, então, com a necessidade de informação dos consulentes de um material terminográfico (nos moldes da TGT), Gaudin alega a não-expressividade como fator fundamental para a ineficácia desses materiais, ou seja, sua crítica se dirige ao fato de que tais obras não expressam efetivamente a realidade dos usos terminológicos por não considerarem o contexto e a situação de produção do discurso especializado, elementos que, ao contrário do termo isolado, garantem a informação. Segundo Krieger e Finatto (2004, p.35),

[...] as orientações prescritivas desconsideram o real funcionamento da linguagem na elaboração de produtos terminográficos, porque não registram as variações denominativas e conceituais que os termos seguidamente comportam. Em conseqüência, deixam de atender a muitas necessidades informacionais dos usuários.

Assim, a Socioterminologia admite a variação terminológica, prevendo a existência de polissemia e sinonímia. Além disso, por considerar o ambiente de produção do discurso especializado, também vai contra a estaticidade dos campos semânticos, denominando-os "nódulos de conhecimento", os quais podem variar de acordo com o tempo, com a intercomunicação de áreas afins e com a evolução dos conhecimentos; assim, o estudo diacrônico da história da conceptualização e denominação é bem-vindo aos estudos terminológicos (TEMMERMAN, 2000, p.32).

Já o grupo liderado por Maria Teresa Cabré, idealizadora dessa nova perspectiva teórica que surge em 1999, a TCT, parte do questionamento crítico e sistemático à TGT, traçando, assim, novas perspectivas teórico-metodológicas para a Terminologia.

A teoria proposta surge de necessidades informativas e comunicativas novas, além de novas aplicações terminológicas, graças ao avanço das ciências e técnicas e, sobretudo, à difusão desse conhecimento especializado para públicos de diferentes níveis de especialização. A TGT continua sendo considerada bastante pertinente, porém para fins 
normalizadores e objetivamente destinada à comunicação entre especialistas, não visando uma difusão mais ampla desse conhecimento.

A TCT é então concebida como uma matéria interdisciplinar, formada pela teoria do conhecimento - que trata da conceptualização da realidade, dos tipos de conceptualizações que se podem dar e das relações que ocorrem entre os conceitos e suas possíveis denominações; pela teoria da comunicação - já que leva em consideração a situação de produção, o tipo de comunicação envolvida e as características que podem ter os termos em diferentes sistemas de expressão e a teoria da linguagem - uma vez que as unidades terminológicas fazem parte da linguagem natural e têm parte de suas características, ainda que com algumas especificidades de significação.

Partindo do princípio de que as unidades léxicas de uma língua são unidades denominativo-conceptuais, capazes de referir-se e exercer funções (função referencial, expressiva, conativa, etc.), e que são integradas ao discurso para construir a argumentação, podemos dizer que não há uma fronteira clara entre unidade léxica e termo. Todas as unidades léxicas de uma língua podem ser consideradas termos ou palavras, fato que somente podemos afirmar em função do contexto e da situação de uso em que estão inseridas, através de uma seleção de traços (semânticos, morfológicos, pragmáticos...) que sejam inerentes ao domínio em questão.

Assim, o objeto de estudo da Terminologia é a unidade terminológica, que forma parte da linguagem natural e integra o sistema gramatical de uma língua.

Essa nova concepção pretende, então, a compreensão das unidades terminológicas como unidades sociais e multidimensionais, na medida em que fazem parte das diferentes línguas e cumprem funções, além da denominativa, também lingüísticas, culturais, sociais, econômicas e políticas. Segundo Cabré (1999, p. 148):

Los términos además de denominar los objetos sirven para expresar las diferencias conceptuales ligadas a la cultura de una comunidad, grupo social o escuela profesional, para preservar dicha cultura más allá de la uniformidad que pretende imponer la globalización informativa actual, sirven también para convencer o mover la acción, para esconder información a determinados grupos, para comerciar, afirmarse lingüísticamente o jerarquizar grupos sociales. El carácter multidimensional del lenguaje se refleja en los términos en cuanto unidades que forman parte de él y que se actualizan dentro de una lengua determinada. 
Desse modo, a TCT permite determinado grau de variação, tanto conceptual quanto denominativa, uma vez que as unidades terminológicas têm como ambiente natural o texto, estão inseridas em contexto e aparecem em um discurso específico, com finalidades específicas. Seu foco recai, principalmente, na concepção de que os termos não são isolados das palavras da comunicação geral e tampouco fazem parte de um sistema de comunicação e expressão distinta, mas pelo fato de que são encobertos por elas. Assim, o que diferencia uma unidade léxica de uma terminológica é uma certa especificidade de sua significação em relação ao léxico geral e fatores funcionais.

Além disso, as unidades terminológicas são constituídas por forma e conteúdo, sendo que o conteúdo é simultâneo à forma - o que lhes confere uma determinada relatividade, já que se definem pelo seu lugar e situação de uso. Ainda segundo a Autora (1999, p.132):

\footnotetext{
Un contenido puede ser expresado con mayor o menor rigor por otras denominaciones del sistema lingüístico - y constituye una nueva unidad lingüística de contenido especializado relacionada semánticamente con la primera - o de otros sistemas simbólicos - y conforma una unidad no lingüística de contenido especializado.
}

Os conceitos também se encontram relacionados semanticamente, formando uma estrutura de conceitos, ou estrutura conceptual da área especializada em estudo. Dessa maneira, cada termo adquire seu valor pelo lugar que ocupa nessa estrutura de conceitos. Vale ressaltar que os termos, diferentemente do que ocorria com a TGT, "no pertenecen a un ámbito, sino que son usados en un ámbito con un valor singularmente específico" (CABRÉ, 1999, p. 124).

Assim, o objetivo primeiro desta vertente teórica é a descrição formal, semântica e pragmática de unidades lexicais que podem ter o caráter de terminológicas. Neste sentido, a TCT objetiva servir à representação e à divulgação do conhecimento técnico-científico em seus mais diversos graus de especialização, o que se realiza por meio da análise do comportamento in vivo das unidades lexicais e das relações que estas estabelecem com as outras unidades do mesmo âmbito comunicacional.

Metodologicamente, a prática terminológica pressupõe três competências, quais sejam: cognitiva, lingüística e sócio-funcional. A competência cognitiva relaciona-se ao 
conhecimento que um lingüista deve ter da área que se pretende descrever, já que, sem ele, não se pode identificar sua terminologia, nem tampouco estruturá-la. A competência lingüística abrange o conhecimento da(s) língua(s) na(s) qual(is) se veicula o conhecimento técnico; já a competência sócio-funcional relaciona-se às características de um trabalho terminográfico para que este seja coerente com seus propósitos e adequado a seu públicoalvo. Além dessas competências, deve-se buscar uma metodologia de trabalho que traga homogeneidade e sistematicidade à obra.

Em suma, o eixo que impulsionou essa nova corrente teórica foi, sobretudo, a inserção do papel social-comunicativo da terminologia que, impulsionada pela pragmática e ciência cognitiva, pôde delinear um novo parâmetro de análise e tratamento para os trabalhos terminológicos.

\subsubsection{Terminologia sócio-cognitiva}

De viés mais recente, a Teoria Sociocognitiva da Terminologia, liderada por Temmerman (2000), dá relevo aos modelos cognitivos para explicar os fatos terminológicos. Segundo a Autora, existe uma nítida relação entre os processos de categorização e a linguagem, sendo muitas unidades terminológicas passíveis de denominarem categorias, tornando-se, assim, unidades com maior índice de prototipicidade.

O modelo propõe, então, a substituição de conceito por unidade de entendimento (unit of understanding), já que poucos são os conceitos que de fato podem definir-se por si sós. Assim, estruturando essas unidades de entendimento de forma prototípica, pode-se melhor compreender as ciências atualmente, uma vez que estas se encontram em constante evolução.

Para alcançar o conteúdo dessa unidade de entendimento deve-se recorrer ao texto, ambiente natural das terminologias. Isso porque os conceitos não podem ser considerados imutáveis, estáticos ou universais, mas sim uma "expressão de um conjunto de elementos de natureza lingüística, que se consubstanciam num texto que possui não apenas uma dimensão lingüística, mas também pragmática, discursiva e comunicativa” (BARROS, 
2006, p.25). Assim, há que se analisar o funcionamento, em contexto, de um termo, antes de dar-lhe um conceito previamente estabelecido.

A teoria sociocognitiva muito se aproxima, por isso, dos estudos de lingüística textual, dando-lhe relevância, já que seu pressuposto é estudar os termos a partir de textos, uma vez que "el léxico constituye una ventana privilegiada para estudiar y dar cuenta de problemas relativos a los módulos superiores del texto y a la tipificación de los textos de especialidade" (CIASPUCIO, 2003, p.115) - do que decorre uma outra distinção importante dessa teoria frente à TGT, por exemplo: o estudo parte do termo, e não do conceito.

Segundo Ciaspusio (2003, p. 115):

\begin{abstract}
Los textos en tanto 'ofertas de conceptualización' representan y presentan determinado 'estado de cosas' a sus intérpretes, para que estos construyan - sobre esa base y en interacción con sus conocimientos, experiencias y creencias previas - una determinada interpretación. El llenado conceptual de las unidades léxicas puede reconstruirse en el texto, si se concibe a éste como un despliegue de su llenado semántico; inversamente, la unidad léxica extraída del texto concentra así los conocimientos asociados con ella en ese texto particular.
\end{abstract}

Porém, o que mais diferencia esta teoria das demais anteriormente apresentadas é o fato de a Autora considerar a unidade de entendimento como uma categoria. Uma categoria pode ser descrita como portadora de um núcleo e uma estrutura delimitada, mas em processo de contínua reformulação. As categorias têm estruturas prototípicas que recolhem informação intercategorial (entre categorias) e intracategorial (no interior da mesma categoria). Sua existência não independe da língua, podendo ser observada no discurso, o que permite identificar mais módulos de informação do que por meio de características diferenciadoras ou posição numa classificação lógica ou ontológica. Do ponto de vista intracategorial, pode-se deduzir uma definição nuclear (por exemplo, parte de), informação histórica, procedimental, etc.; do ponto de vista intercategorial podem ser estudados o domínio, como a perspectiva e a intenção do modelo cognitivo usado (LARA, 2006).

Baseada na variação de nível e de grau de especialização do emissor e do receptor de uma informação terminológica, e também do tipo de unidade a ser tratada, a informação relevante para constar da definição também varia, não levando em consideração os modelos tradicionais de definição, por extensão e intensão. 
Uma outra questão, já esperada, é a aceitação da sinonímia e polissemia entre as unidades de entendimento. Segundo a teoria cognitivista, existe uma flexibilidade em seus modelos, e também uma certa variedade no processo de categorização, fato que justifica a ocorrência de unidades sinônimas e polissêmicas no universo da comunicação especializada.

Um outro fato interessante trata da evolução das unidades do conhecimento. Uma vez que não são consideradas estáticas, tendo seu sentido alterado com o decorrer do tempo, se faz, em alguns casos, fundamental estudar essa trajetória para uma compreensão mais ampla da unidade, dependendo, neste caso, da importância histórica que cumpriu tal unidade. Descarta-se, então, a análise puramente sincrônica com a qual vem trabalhando a Terminologia.

Finalmente, modelos cognitivos desempenham um papel importante no desenvolvimento de novas idéias, o que se traduz em Terminologia pelas metáforas, por exemplo. Sendo assim, pode-se esperar determinada motivação para a seleção ou criação de termos, desmistificando a arbitrariedade entre termo e conceito proposta palas teorias mais tradicionais. Esse modelo (Idealized Cognitive Models - ICM) pressupõe a necessidade de melhor compreensão dos fatos científicos, justificando o uso de modelos cognitivos para a denominação. Além disso, a motivação terminológica permite grande interação entre pesquisadores e usuários de diferentes línguas no que concerne à compreensão de unidades de conhecimento especializado.

Necessidades novas requerem outras e diferentes formas de tratamento; assim, a Terminologia, enquanto ciência relativamente recente, apresenta novas tendências de análise. E seu vigor reside, justamente, no fato de trabalhar em interface com outros campos científicos: "Em uma relação de interação, essas áreas beneficiam a terminologia com seus achados, por um lado; por outro, as necessidades das pesquisas terminológicas tornam-se desafios para essas ciências, o que impulsiona o desenvolvimento delas" (BARROS, 2006, p.26). Uma revisão teórica torna-se, assim, bastante pertinente, à medida que resgata e traz novas possibilidades de atuação para a Terminologia, ampliando seus horizontes de pesquisa. 


\subsection{Aplicações dos estudos terminológicos}

Muitas são as aplicações dos estudos terminológicos, uma vez que a Terminologia se constitui uma disciplina em cooperação com diversas áreas, as quais, segundo Barros (2006, p.23-25), são as seguintes: tradução especializada, documentação, jornalismo científico, ciências sociais, ensino de línguas e de disciplinas técnicas e científicas, além de se prestar ao planejamento lingüístico e à normalização terminológica, entre outras.

Vejamos, sob o olhar da Autora, algumas implicações da Terminologia para as diferentes áreas:

- Tradução especializada: A tradução especializada faz uso da Terminologia à medida que, para uma adequada tradução, o tradutor deve dominar, além do conhecimento da área que se propõe a traduzir e das línguas de partida e chegada, também a terminologia empregada para o domínio em questão.

- Ensino de línguas: a aquisição de conhecimento, sobretudo em língua estrangeira, se dá através da apropriação vocabular, e assim da estrutura do sistema lingüístico em questão. Esse vocabulário vem permeado de terminologias, e o uso de dicionários bilíngües, multilíngües e monolíngües, especializados e de língua geral, são fundamentais nesse processo.

- Ensino de disciplinas técnicas e científicas: para uma correta interpretação dos fatos técnico-científicos, expressos por textos especializados, é necessário que os alunos/aprendizes possam decodificar as unidades terminológicas ali presentes; e é nesse ponto que a Terminologia pode facilitar o caminho da comunicação especializada no ensino dessas disciplinas, por meio da elaboração de estratégias e instrumentos de suporte para o ensino.

- Ciências sociais: todos os elementos socioculturais são designados por unidades lexicais que, consideradas como signos lingüísticos de domínios específicos de atividade comunitária, podem assumir o estatuto de termo. Nesse sentido, a Terminologia pode dar grande contribuição, procedendo ao levantamento, análise, sistematização e descrição dos termos utilizados pela comunidade sociocultural em setores específicos de sua vida. 
- Documentação: Documentação e Terminologia também são ciências que andam de mãos dadas. A primeira, por meio da indexação de seus documentos, utiliza-se de tesauros, materiais elaborados em cooperação com a Terminologia; já a segunda trabalha com textos especializados, identificados, analisados e organizados pela Documentação.

- Jornalismo cientifico e técnico: ambas as profissões utilizam-se da Terminologia no sentido de que seus profissionais deparam-se com temas e textos de especialidade diariamente, seja na compreensão dos fatos ou na divulgação dos mesmos.

- Planejamento lingüístico: uma outra aplicação da Terminologia é no planejamento lingüístico, que pode ser definido como "o processo de intervenção do Estado com o objetivo de modificar de um modo ou de outro o comportamento lingǘstico de seus cidadãos" (BARROS, 2006, p.25). Assim, na consolidação da política internacional, a comunicação livre de ruídos é de fundamental importância.

Ainda sobre o mesmo tema nos diz Maria da Graça Krieger (2006, p. 47):

\begin{abstract}
Diante da funcionalidade operada pelos termos especializados na transmissão de conhecimentos científicos e técnicos e na divulgação de produtos e serviços, justifica-se a necessidade de concretizar um projeto terminológico para um contexto de integração regional como o Mercosul. Conseqüentemente, é um importante recurso estratégico organizar e facilitar o acesso a repertórios terminológicos que privilegiam áreas de interesse das sociedades que buscam se integrar na busca de seu fortalecimento.
\end{abstract}

- Normalização terminológica: a normalização terminológica pressupõe a comunicação eficaz entre especialistas, temática recorrente de comitês nacionais e internacionais. Para tanto, a padronização de uso de termos é ponto-chave para seu sucesso, o que ocorre por meio de divulgação de normas de emprego de determinados termos, em detrimento de outros.

Algumas implicações dos estudos terminológicos foram acima mencionadas. Tais recortes justificam a busca constante por renovação de conhecimentos e parcerias com outras áreas de estudo, como por exemplo, a informática, a lingüística de corpus e textual, 
entre outras, o que vem rendendo grandes progressos nas aplicações terminológicas envolvidas nas mais diversas áreas de atuação profissional e acadêmica.

\title{
2.3. Língua Geral X Língua de Especialidade
}

De acordo com o IULA (2004a):

\begin{abstract}
Las necesidades de comunicación del mundo actual, marcadas por su carácter plurilingüe y por un grado importante de especialización, han hecho aumentar las necesidades de comunicación especializada para la que se utilizan lenguajes especializados o lenguajes de especialidad. No es unánime, sin embrago, el uso del término lenguaje; para referirse a los recursos de la comunicación especializada, algunos autores usan el término sublenguaje; otros, el término tecnoleto, y hay quienes hablan jerga técnica.
\end{abstract}

Denominações à parte, fala-se em língua geral para a referência ao conjunto de recursos lingüísticos empregados pela maioria dos falantes de uma língua, reservando-se o termo língua de especialidade para denominar o subconjunto dessa língua que se atualiza na comunicação especializada pela temática.

Atualmente, vem sendo preferida a denominação linguagem de especialidade, uma vez que a linguagem reflete uma manifestação da língua em uso. Além disso, as áreas de especialidade recortam os recursos lingüísticos que as expressam mais adequadamente, característica, aliás, construída por cada universo de discurso em particular.

Assim, a linguagem especializada se distingue da linguagem geral em dois aspectos específicos: características de texto e uso de um léxico ou de uma terminologia específica, além da representação com sistemas simbólicos não-lingüísticos, em proporção variada de acordo com a disciplina.

A comunicação especializada, ainda que faça uso de linguagem natural e da mesma gramática da língua geral, apresenta maior concisão e sistematicidade expressivas e maior precisão de conteúdo em relação à comunicação geral; além disso, o discurso produzido por especialistas na área-objeto, e também a direção da comunicação - para especialistas, quase-especialistas e para a divulgação de conhecimento especializado - são fatores de diferenciação para a comunicação geral. 
Com relação às características do texto especializado, pode-se dizer que, segundo o IULA (2004a),

\begin{abstract}
Un texto técnico debe ser preciso, porque solo así el conocimiento que transmite es especializado y porque así lo requiere la temática científico-técnica y las relaciones funcionales entre especialistas. Debe ser además tan conciso como sea posible, en la medida en que la concisión hace disminuir la probabilidad de que se produzcan distorsiones en la información. El grado de concisión de un texto, y complementariamente su grado de redundancia, varía en función de la situación comunicativa en que se produce, de forma que el nivel de concisión disminuye de acuerdo con el grado de conocimiento de los destinatarios (menos expertos que el emisor) y de la función que el acto comunicativo persigue (intercambiar, enseñar o divulgar sin más) el conocimiento. Así, los textos especializados pueden presentar diferentes niveles de especialización, a mayor especialización se supone menor inteligibilidad para los receptores no expertos.
\end{abstract}

Em resumo, a noção de linguagem de especialidade é fundamentalmente ativada pela pragmática: a língua natural considerada como instrumento de transmissão de conhecimento especializado (LERAT, 1997, p.17).

\title{
2.4. Termo X Palavra
}

A Terminologia, enquanto disciplina, se ocupa do estudo das unidades terminológicas - unidades léxicas utilizadas de maneira precisa dentro de um âmbito de especialidade para representar ou comunicar os conceitos desse domínio.

Para melhor estudá-las, é preciso delimitar os conceitos de termo e de palavra, muitas vezes difusos em alguns momentos da prática terminológica.

Dois são os panoramas pelos quais passaram as concepções de termo e de palavra. Partindo de uma concepção mais reacionária e pouco aceita atualmente, termo e palavra são elementos totalmente distintos, pertencentes a universos específicos e bastante distanciados um do outro; em seguida, passou-se à percepção de que termos e palavras podem denominar realidades específicas, as áreas especializadas; mais contemporaneamente, chegou-se ao abandono da dicotomia termo X palavra, já que somente o uso pode dar o status de termo a unidades lexicais de uma língua.

Vejamos tais pontos de vista e suas implicações para a ciência da linguagem.

De acordo com a Terminologia clássica, a Teoria Geral da Terminologia - TGT, iniciada com os estudos de Wüster, os termos se configuravam como uma linguagem à 
parte, não compartilhando das mesmas regras de formação de palavras e estruturas léxicas. De acordo com essa perspectiva, mais tradicionalista e normativa, Coseriu (1986, p.96) nos dá a seguinte definição de termo:

As terminologias científicas e técnicas não pertencem à linguagem, nem, por conseguinte, às estruturações léxicas do mesmo modo que as 'palavras usuais': constituem utilização da linguagem para classificações diferentes (e, em princípio, autônomas) da realidade ou de certas seções da realidade. Em parte, as terminologias não estão 'estruturadas' em absoluto (são simples 'nomenclaturas' enumerativas que correspondem a delimitações nos objetos) e, nessa medida, sua estruturação não corresponde às normas da linguagem, mas a pontos de vista e às exigências das ciências e técnicas respectivas, que se referem à realidade mesma das coisas.

Assim, os termos eram considerados meros substitutos lingüísticos da realidade objetiva, não apresentando uma estruturação semântica, mas apenas classificações objetivas da realidade (COSERIU, 1986, p.96).

Já de acordo com Sager (1990, p.18), os termos, ou "special subject languages”, são subsistemas lingüísticos utilizados em discurso especializado; em suas palavras, "the linguistic subsystem selected by an individual whose discourse is to be centred on a particular subject field". Assim, o Autor diferencia a língua geral das línguas de especialidade, declarando que existe, para as últimas, maior restrição ou definição de conceitos, e que estes, portanto, são representados por unidades lexicais mais transparentes.

Porém, admite que o vocabulário especializado pode conter itens lexicais desprovidos de referência especial ("special reference"), utilizando-se de itens que, geralmente, não apresentam especificidade para uma determinada área ou áreas do conhecimento, ou seja, que estão mais próximos do léxico geral, acumulando assim dupla função: fazer referência geral e específica.

Sager (1990, p.19) apresenta sua definição de termo e de palavra da seguinte maneira:

The items which are characterized by special reference within a discipline are the 'terms' of that discipline, and collectively they form its 'terminology'; those which function in general reference of a variety of sublanguages are simply called 'words', and their totality the 'vocabulary'. 
Atualmente, porém, observa-se uma situação bastante diversa. Nota-se que as nomenclaturas técnico-científicas eram constituídas primordialmente por formantes grecolatinos, fato que garantia maior rigor aos termos, não deixando margem a ambigüidades. Hoje, o avanço das ciências e das técnicas, bem como a difusão do conhecimento especializado, proporcionam maior permuta entre o léxico geral e especializado, indeterminando ou não-marcando linha divisória entre eles. Segundo Krieger, Maciel e Finatto (2002, p. 317-318):

[...] os termos técnicos e/ou científicos deixaram de se configurar como uma 'língua à parte', não sendo mais facilmente identificados como ocorria quando, ao modo das nomenclaturas, correspondiam a palavras muito distintas da comunicação ordinária e permaneciam praticamente restritos aos diferentes universos comunicacionais especializados. Hoje, os termos circulam intensamente, porque ciência e tecnologia tornaram-se objeto de interesse de sociedades, sofrendo, conseqüentemente, processos de vulgarização, favorecidos pelas novas tecnologias de informação.

Desse modo, ainda que haja termos de circulação restrita por seu elevado grau de especialização, “[...] não há mais fronteiras rígidas que demarcam os universos do léxico comum e do especializado" (KRIEGER, MACIEL, 2001, p.317-318).

Segundo Cabré (1999, p.25), os termos não apresentam nenhuma especificidade frente às palavras do léxico comum, já que ambos, desde um ponto de vista lingüístico, apresentam igualdade gráfica e fônica, estrutura morfológica simples ou complexa, são gramaticalmente caracterizados e possuem significado que descreve a classe a que pertence um objeto particular.

Lerat (1997, p.22), ainda que não faça tais diferenciações, também afirma que os vocabulários especializados tendem a apresentar características de formação lexical bastante próximas do léxico geral; segundo o Autor, abusam do processo de flexão, derivação, afixos de raiz greco-latina, composição sintagmática e também dos empréstimos terminológicos. Ressalta, ainda, a importância do estudo da morfologia para a compreensão dos processos terminológicos.

Um organograma com os processos de formação de unidades terminológicas resume e apresenta essa característica, e é apresentado pelo IULA (2004b): 


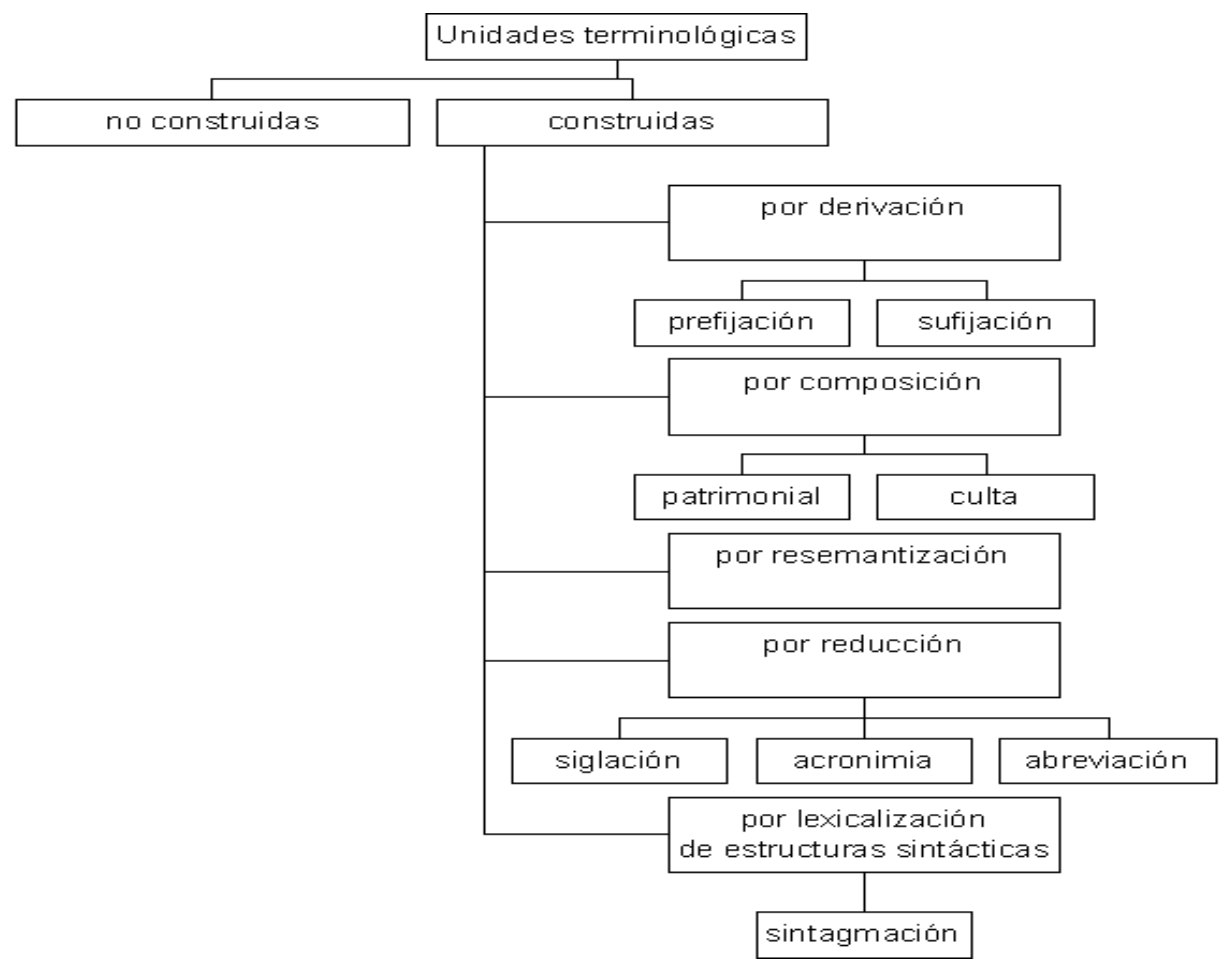

Figura 1 - Processos de formação de unidades terminológicas

Assim, os termos parecem não diferir muito das palavras, considerados segundo uma perspectiva formal ou semântica; mas se diferenciam notavelmente quando os analisamos segundo critérios pragmáticos e comunicativos.

Por isso, ponderam os pesquisadores do IULA (2004b),

Los términos no forman parte de un sistema independiente de las palabras, sino que forman parte del léxico del hablante. Al mismo tiempo, se distinguen de las unidades que suelen denominarse palabras (y que aquí denominaremos unidades léxicas sin valor especializado o no términos) por su contenido preciso y bien delimitado en el contexto de uso de una materia especializada. En consecuencia, no parece adecuado defender una separación taxativa entre palabras y términos porque, de un lado, no da cuenta de las similaridades gramaticales entre estos dos tipos de unidad, y, por otro, no explica por qué hay unidades que pueden ser términos o no términos según el contexto temático y comunicativo en el que se utilicen. Es en esta vía que consideramos que el carácter de término es un valor asociado virtualmente a toda unidad del léxico, que a veces se desarrolla sólo en cuanto a tal valor especializado (por ejemplo, ácido desoxirribonucleico), otras solo aparece en la comunicación de carácter general (por ejemplo el verbo dar), pero en el mayor número de casos puede ser usada como término o como no término (por ejemplo, cadena o neurona). Se usa como término cuando, en el contexto de una materia especializada precisa (por ejemplo cadena en Genética, en Tecnología audiovisual o en Fonética), actualiza un significado preciso y delimitado dentro de la materia, dicho de otro modo, expresa un concepto pertinente en la estructura conceptual de dicha materia. 
Cabré (1999, p.25) faz, porém, uma ressalva quanto à produtividade dos processos de formação de termos frente às palavras do léxico geral, o que se pode comprovar com os resultados estatísticos obtidos com a pesquisa em Genética Molecular (ver item 3.2.):

[...] los modos de formación de los términos no tienen la misma frecuencia que las palabras del léxico general. En terminología, las unidades compuestas por formantes cultos y las construcciones sintagmáticas fijas suelen tener un rendimiento mucho más elevado que en lexicología general.

Contudo, percebemos uma evolução e mudança de ponto de vista em relação à antiga questão: o que é termo, o que é palavra. Os estudos mais recentes em Terminologia, que se baseiam na pragmática para tal diferenciação, tangenciam a lingüística textual modelo adotado também pela Terminologia Sócio-cognitiva, de Temmerman - já que são os textos fonte de difusão de conhecimento e de expressão das mais diversas áreas de especialidade. Como dito previamente, os conceitos são atualizados pelos textos, de modo que estes se tornam indispensáveis para uma adequada descrição terminológica.

Assim, como citado anteriormente, o caráter especializado dos termos pode ser descrito como um valor agregado às unidades léxicas; quando ativado tal valor, a unidade léxica se converte em unidade terminológica. $\mathrm{O}$ caráter terminológico é, portanto, um valor pragmático aferido pelas condições discursivas nas quais um texto especializado é produzido, ou seja, em função de seu uso em contexto expressivo e situacional determinado. Conseqüentemente, pode-se dizer que uma unidade léxica é formada por um conjunto de parâmetros semânticos, que se ativam em função de seu emprego em um domínio concreto.

O que podemos concluir a partir dessa evolução nos vieses teóricos para a (na) análise das unidades terminológicas é que em muito contribuíram a lingüística textual e a pragmática para o avanço dos estudos terminológicos, uma vez que não somente as unidades terminológicas, mas também o entorno textual faz parte do trabalho de um terminólogo - e também implica uma nova denominação para essas unidades, que passam a ser chamadas Unidades de Conhecimento Especializado - UCEs. 


\title{
2.4.1. As unidades de conhecimento especializado - UCES
}

Uma definição bastante clara sobre as UCEs pode ser encontrada em IULA (2004b):

\begin{abstract}
Las unidades de conocimiento especializado (UCE), que se combinan y relacionan entre sí en los textos especializados estableciendo redes conceptuales, abarcan desde los morfemas hasta las unidades oracionales, pasando por las unidades léxicas y las unidades fraseológicas. En consecuencia, según nuestra propuesta, las unidades terminológicas, si bien son las unidades más prominentes y prototípicas de los textos especializados, no son las únicas unidades que transmiten conocimiento especializado.

Y solo a partir de un análisis progresivo de las UCE y sus relaciones podemos dar cuenta de la estructura del conocimiento especializado de un texto y, a la larga, de la estructura conceptual potencial de una materia específica.
\end{abstract}

Dessa maneira, ainda que as unidades terminológicas sejam consideradas as mais representativas e prototípicas de uma nominata específica, outras unidades léxicogramaticais podem representar o mesmo papel - é o caso das unidades oracionais e fraseológicas, supracitadas.

No corpus de pesquisa elaborado para este trabalho, aproximadamente $69 \%$ das unidades representativas do domínio estudado são compostos sintagmáticos, o que comprova a veracidade de tal estudo. A análise dos processos de formação da terminologia da Genética Molecular está listada no item 4.1.

Vale ressaltar que, ainda que a denominação utilizada para as unidades terminológicas, neste trabalho, seja termo, estamos tratando de todos os elementos léxicos representativos da área-objeto em estudo, que podem ser representados por unidades lexicais simples ou compostas, por sintagmas, por siglas, etc. 


\section{A pesquisa}

\subsection{Identificação e seleção de termos: constituição do corpus de trabalho}

Antes de tratarmos efetivamente sobre a constituição do corpus de trabalho, enfatizaremos a delimitação da área-objeto, fundamental para a adequada seleção de fontes de consulta bibliográfica e, conseqüentemente, para a seleção dos termos que comporão a nomenclatura a ser analisada.

Levando-se em conta que, para a elaboração (posterior) da estrutura conceitual, "há que se conhecer o campo especializado com o qual se está trabalhando, ou então, ter assessoria permanente dos especialistas da área, pois é necessário reconhecer os conceitos em textos, agrupá-los em distintos campos nocionais e estabelecer as relações entre eles" (ALMEIDA, 200, 119), um organograma de delimitação da área-objeto foi pré-elaborado, a fim de se visualizar mais claramente os limites da pesquisa.

Assim, partimos da Genética lato sensu e favorecemos uma de suas ramificações para receber tratamento, qual seja, a Genética Molecular; em seguida, suas subáreas (das quais trataremos mais especificamente em seguida).

Vale ressaltar que tal esquema foi baseado em tabela de áreas e subáreas relativas à Biologia de modo geral, elaborada pelo Conselho Regional de Biologia ${ }^{11}$ :

\footnotetext{
${ }^{11}$ Disponível em $<$ http://www.crbio3.org.br/noticias/index.php?id=1063\&idcategoria=7>
} 


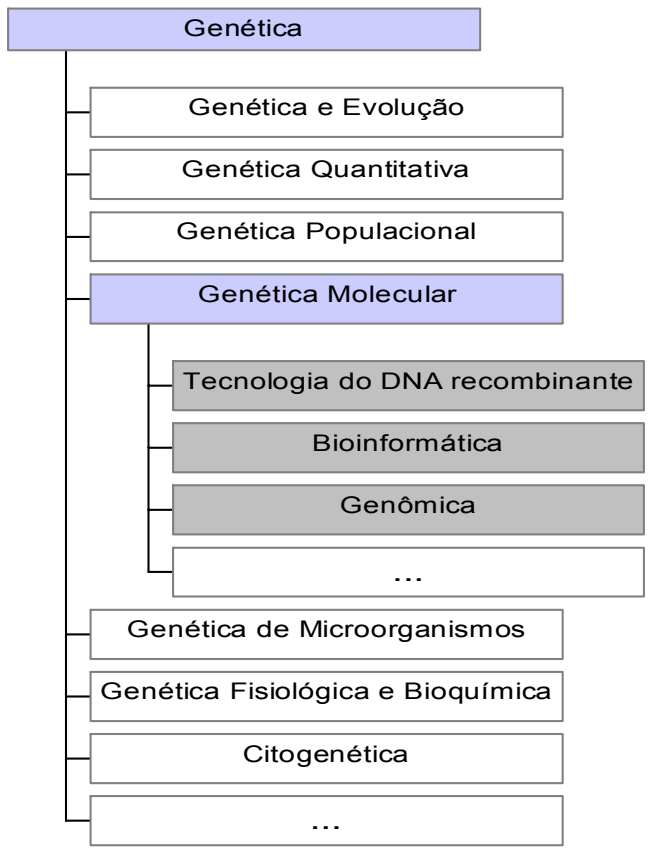

Figura 2. Delimitação da área-objeto.

Assim, pudemos dar início à consulta de materiais bibliográficos pertinentes à pesquisa.

Para a recolha de termos referentes à área-objeto em estudo, foram indicadas obras de referência em Genética Molecular, indicação essa feita por alguns especialistas, professores da Universidade Federal de São Carlos - UFSCar ${ }^{12}$, Universidade de São Paulo - USP (campus São Carlos) ${ }^{13}$ e da EMBRAPA - Empresa Brasileira em Pesquisa Agropecuária $^{14}$, também localizada em São Carlos.

Dentre as obras sugeridas, foram utilizadas somente aquelas de publicação mais recente. Isso se justifica pelo fato de a ciência genética estar em plena evolução, o que acarreta uma mudança terminológica, e ademais, um processo de criação terminológica

\footnotetext{
${ }^{12}$ Dentre eles estão o Prof. Flavio Henrique da Silva, o Prof. Euclides Matheucci Júnior (ambos Professores do Departamento de Genética e Evolução - UFSCar ) e a Profa. Heloísa Sobreiro Selistre de Araújo (Professora do Departamento de Ciências Fisiológicas - UFSCar).

${ }^{13}$ Prof. Otávio Thiemann e a Profa. Ana Paula Ulian Araújo (ambos Professores do Instituto de Física IFSC).

${ }^{14}$ Profa. Luciana Correia de Almeida Regitano.
} 
acelerado. Assim, materiais de publicação mais antigos certamente não utilizariam a mesma terminologia, e nem poderiam, em vista das recentes descobertas científicas, das novas técnicas e materiais empregados na área da Genética.

Em razão da abrangência da área-objeto, procedemos a uma nova delimitação da área, o que resultou no enxugamento da bibliografia que seria consultada. Por sugestão da Profa. Heloísa e por uma questão de praticidade e relevância dentro da área, foram escolhidas três subáreas da Genética Molecular para receber o tratamento terminológico, quais sejam: Tecnologia do DNA recombinante, Genômica e Bioinformática. Isto porque, dentro dessas três subáreas, encontram-se os principais métodos e técnicas em Genética, bem como os processos de manipulação de DNA e das estruturas utilizadas para tal finalidade. Duas outras áreas foram incluídas a posteriori: Genética básica e Regulamentação, visto que alguns termos, fundamentais para a compreensão da área, não se encaixariam adequadamente nas três subáreas previamente eleitas para receber tratamento - caso da Genética básica; outros termos, como os órgãos regulamentadores da área, também mereceram tratamento para este trabalho, por sua importância em âmbito nacional. Um organograma representativo dessas subáreas está apresentado em 4.2. (Figura 6).

Vale ressaltar que em fase posterior do trabalho poderemos abranger um pouco mais o leque da disciplina, priorizando também outras subáreas.

Segue, então, uma lista com as obras efetivamente consultadas:

a) Genômica. Organização editorial Luís Mir. São Paulo: Editora Atheneu, 2004.

b) GRIFFITHS, AS.F. [et. al]. Genética moderna. Rio de Janeiro: Guanabara Koogan, 2001.

c) GIBAS, C., JAMBECK, P. Desenvolvendo Bioinformática: ferramentas de software para aplicações em biologia. Revisão técnica Antônio Basílio de Miranda; tradução Cristina de Amorim Machado; tradução Milarepa Ltda. Rio de Janeiro: Campos, 2001.

d) MINISTÉRIO DA AGRICULTURA, PECUÁRIA E ABASTECIMENTO. Empresa Brasileira de Pesquisa Agropecuária. Embrapa Pecuária Sudeste. Biologia molecular aplicada à produção animal. Brasília, DF: Embrapa Informação 
Tecnológica, 2001.

e) Conselho de Informações sobre biotecnologia. $<\underline{\text { http://www.cib.org.br }>}$

f) Revista Pesquisa Fapesp - Ciência e Tecnologia no Brasil. Edições de jan.05/ jan.07.

g) Periódicos e artigos eletrônicos.

De posse desses materiais, pudemos dar início à busca dos termos da área. Para tanto, algumas teorias sobre a definição de termo X palavra, bem como sobre critérios para a identificação de terminologias foram estudadas (ver item 2.3).

Levando-se, então, em consideração que as unidades lexicais só se tornam termos quando são definidas e empregadas em textos de especialidade e que os vocabulários especializados tendem a apresentar características de formação lexical bastante próximas do léxico geral, como por exemplo, flexão, derivação, afixos de raiz greco-latina, composição sintagmática e também por empréstimos terminológicos (LERAT, 1997, p.22), o pesquisador depara-se com a seguinte questão: como, então, reconhecer/segmentar as unidades terminológicas em um texto especializado?

Alguns critérios para tal identificação são apresentados e discutidos por diversos autores. Fatores lingüísticos como os de caráter morfológico (formantes com significado especializado dentro do campo de conhecimento sob análise), os condicionamentos sintagmáticos como a coocorrência e a comutação, o grau de coesão e fixação sintática dos termos, a proximidade de glosas explicativas, a estabilidade da relação entre a forma e o conteúdo em texto especializado (grau de lexicalização do termo), a relação unívoca com o conceito especializado que designa (monossemia), os artifícios tipográficos, a análise contextual, a seleção dos tipos de documentação adequados e também a verificação das particularidades estilísticas dos diferentes níveis de linguagem são todos tratados como índices para o reconhecimento de terminologias. Porém, são todos eles infalíveis? Até que ponto são realmente índices para a identificação de unidades terminológicas?

De acordo com Lerat (1997, p.50), todo o processo de busca e reconhecimento de termos em textos especializados se ampara em critérios lingüísticos: 
[...] 1) pertenencia a una serie morfológica de palabras con significado especializado dentro de la lengua considerada; 2) condicionamientos sintagmáticos (coocurrencias y conmutaciones dentro de un ámbito especializado); 3) relaciones de dependencia en relación a unidades que presentan las características 1 y 2.

De fato, alguns tipos de formantes léxicos têm significação especializada em determinadas áreas de conhecimento, sendo a presença de formantes greco-latinos, geralmente, um indício de terminologização. No caso da Genética Molecular podemos citar, a título de exemplo, os seguintes formantes ${ }^{15}$ :

- prefixo bio-: antepositivo, do gr. bíos, ou 'vida', ricamente representado nas línguas de cultura modernas do início do sXIX em diante, sobretudo para a terminologia das biociências. (Fonte: Houaiss eletrônico)

\section{bioética / bioinformática / biomolécula}

- elemento de composição farmac(o)-: antepositivo, do gr. phármakon, ou 'medicamento'; ocorre em voc. já formados no próprio gr., e em compostos da terminologia científica do sXIX em diante. (Fonte: Houaiss eletrônico)

\section{farmacocinética / farmacodinâmica / farmacogenética / farmacogenômica}

- sufixo -ase: em química, é suf. indicativo de enzimas. (Fonte: Houaiss eletrônico)

ligase / nuclease

- sufixo -oma: em biologia, para designar nome de conjuntos ou sistemas (Fonte: Houaiss eletrônico)

genoma, transcriptoma

Ainda segundo o Autor, alguns condicionamentos sintagmáticos como a coocorrência (a freqüência de determinado termo em uma área temática) e a comutação (se comutamos um componente em um sintagma e seu sentido original mantém-se, então não podemos dizer que tal componente seja um termo, mas, ao contrário, se o sentido se altera, é provável que o componente seja uma unidade terminológica), o que Aubert (2001, p.67) denomina "teste de segmentação", podem indicar a presença de um termo:

\footnotetext{
${ }^{15}$ Todos os termos ou excertos que serão apresentados neste subcapítulo foram extraídos da obra Genética Moderna, que consta da bibliografia.
} 
Uma classe especial de repetições em tamdem mostra um número variável em loci diferentes e em organismos individuais diferentes. Estas repetições em tamdem são chamadas de VNTRs, ou número variável de repetições (inserções*) em tamdem, às vezes chamado de DNA minissatélite. (GRIFFITHS, A.S.F. et. al., p. 341)

*entenda-se uma comutação de "repetições” por “inserções”, o que alteraria o significado da expressão.

Um outro critério, abordado por Aubert (2001, p.67-69), é o da proximidade a glosas explicativas e/ou contextos definitórios, explicativos ou associativos.

O Autor entende por contexto associativo aquele que apresenta o termo como pertinente ao tema da pesquisa, não indicando, porém, traços conceptuais específicos; já por contexto explicativo, entende aquele que traz alguns traços conceptuais pertinentes específicos do termo em análise, e que, freqüentemente, trata sobre sua materialidade, finalidade, funcionamento, etc; e, finalmente, por contextos definitórios entende aqueles que trazem um conjunto completo de traços conceptuais distintivos do termo em questão. Estes últimos, geralmente, vêm explicitados através de sinais/marcações lingüísticas como "chamado", "conhecido como", "o termo", etc. Como exemplo, pode-se citar dois excertos retirados da bibliografia da Genética Molecular:

Observe também que o conjunto de fragmentos de DNA amplificados, chamados de DNA polimórfico amplificado aleatoriamente (RAPD, pronunciado 'rapid'), é um outro tipo de fingerprint de DNA que pode ser usado para caracterizar um indivíduo. (GRIFFITHS, A.S.F. et. al., p.349)

De um modo geral, o termo biotecnologia é o nome dado a esta área de pesquisa - a aplicação das técnicas de DNA recombinante em empreendimentos comerciais. (GRIFFITHS, A.S.F. et. al., p.310)

Ainda segundo o mesmo Autor, outro critério importante diz respeito às fontes consultadas. O critério da adequação, confiabilidade e representatividade das fontes diz que estas devem ser adequadas/pertinentes ao tema abordado, de autoria reconhecida (autores consagrados na área) e representativa do domínio em questão. Este fator torna-se um dos mais importantes em um trabalho terminológico à medida que tais textos podem ser tidos como "especialistas na área objeto" - haja vista a dificuldade em encontrarmos um especialista que dê suporte a toda a pesquisa ser bastante real. Assim, de posse de materiais 
escritos por professores e cientistas renomados, temos maior garantia da adequação dos termos encontrados e de seu uso efetivo para a área-objeto em questão.

Um outro critério, abordado por Dubuc (1999, p.83), é o do grau de lexicalização do termo. Por este critério analisa-se a coesão entre as partes do sintagma - quanto maior o grau de coesão entre as mesmas, maior o índice de dissociação das partes. Tais índices podem ser expressos por ausência de artigo, adjetivo possessivo ou demonstrativo. Esse critério, porém, não se mostrou infalível para a área em estudo, visto que alguns sintagmas terminológicos apresentam características que contradizem tal premissa (apontado pelo *):

agente imunomodulador

software de modelagem por homologia

sítios de restrição

eletroforese em gel de campo pulsado

*andar no cromossomo

*método do grupo de pares não ponderados utilizando médias aritméticas

Outro critério, apontado também por Dubuc, é o da utilização de artifícios tipográficos, ou seja, a presença de certos marcadores como negrito, itálico, aspas, proximidade de siglas, sublinhados, maiúsculas, etc, também pode evidenciar a existência de um termo:

"A técnica usa um procedimento chamado de reação em cadeia polimerase (polymerase chain reaction - PCR)". (GRIFFITHS, A.S.F. et. al., p. 291)

"Estes trechos são chamados de matrizes abertas de leitura (open reading frames - ORFs)". (GRIFFITHS, A.S.F. et. al., p. 291)

"Importantes papéis para a genética reversa são a mutagênese in vitro e a perturbação gênica, também conhecida como inativação gênica (gene knockout)”. (GRIFFITHS, A.S.F. et. al., p. 310)

Um último critério, dentre os abordados, e trazido por Pavel e Nolet (2002, p.19), é o da monossemia, segundo o qual deve haver uma relação unívoca entre o termo e o conceito especializado que aquele designa. Como exemplo, pode-se citar: 
transcrição: 1 ato ou efeito de transcrever. 2 Rubrica: fonética, lingüística.escrita de dados para estudo lingüístico, procurando registrar a pronúncia real do informante (ger. feita em algum dos alfabetos criados por foneticistas esp. para esse fim) Obs.: cf. alfabeto fonético. 3 Rubrica: genética.síntese enzimática de um ARN mensageiro utilizando uma cadeia de ADN como molde. 4 Rubrica: termo jurídico.operação que consiste em fazer recopiar num registro oficial um ato jurídico. 5 Rubrica: música. arranjo para outra formação instrumental ou vocal que não a original. (Fonte: Houaiss eletrônico)

transcrição: Atividade celular de síntese de RNA a partir de um DNA molde. Este é o primeiro passo na codificação de um gene em proteína, embora nem todos os transcritos produzam proteínas. (Fonte: Genômica - glossário)

Em geral, através destes estudos, pode-se perceber que ainda que existam critérios tidos como índices de reconhecimento de unidades terminológicas, faz-se necessário avaliar a sua eficácia, uma vez que a utilização de um termo em detrimento de outro pode provocar falhas, ou lacunas, em um trabalho terminográfico.

Segundo Aubert (2001, p.63), podemos incorrer em erros de ruído - seleção de termos irrelevantes para o tema proposto - e de silêncio - não-seleção de termos básicos para o domínio. Cabe ainda lembrar que em última instância temos a análise do especialista na área-objeto para a validação dos termos coletados e para o julgamento de quais são realmente pertinentes à área em estudo.

Sendo assim, em seguida à recolha de um número elevado de candidatos a termos, os mesmos foram enviados a professores da área para sua validação, ou descarte.

Inicialmente foram recolhidos 1100 termos (um valor aproximado), dos quais 140 foram descartados pela especialista. Cabe, aqui, explicar e analisar os motivos para esse descarte, uma vez que nos baseamos em fontes confiáveis para tal pesquisa.

Ainda que tenhamos utilizado materiais de publicação recente, alguns termos foram considerados sinônimos menos usados, como, por exemplo: DNA bifilamentar - DNA dupla-fita, DNA quimérico - DNA recombinante, célula de linhagem embrionária - célula de linhagem germinal; outros apresentavam sinonímia entre língua vernácula e estrangeira: transferência de Southern - Southern blooting, buraco - gap. Nestes casos, os termos sinônimos foram alocados em pastas no programa FolioViews 4.2 para posterior análise, já que o presente trabalho não abordará tal temática. Uma tela - Fig. 2, abaixo - mostra esse armazenamento de informação: 


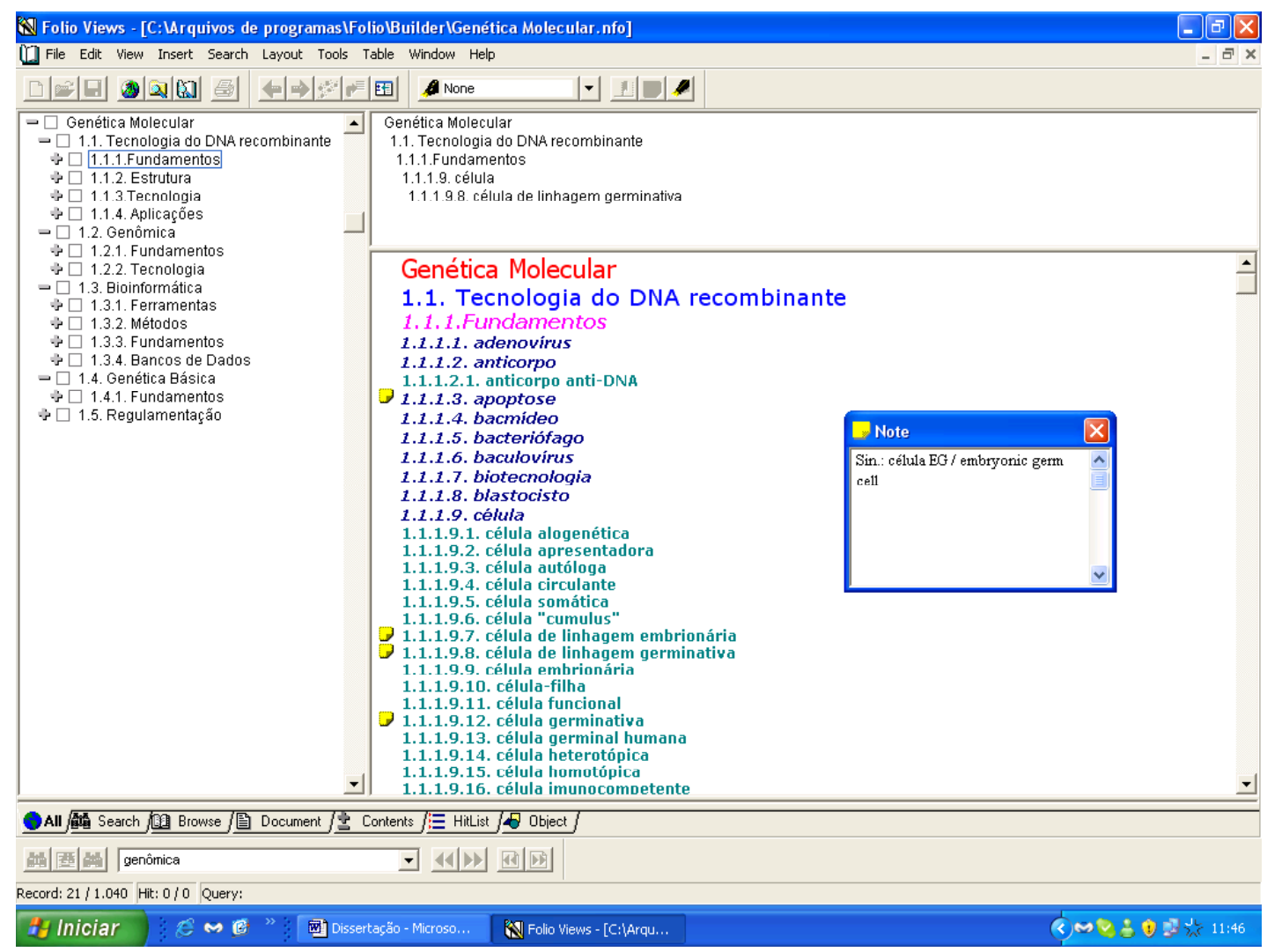

igura

3.

Arma

zena

mento

de

infor

maçõ

es no

Folio

Views

4.2.

utra ocorrência de descarte deveu-se a termos não específicos da Genética Molecular, mas pertencentes à Genética de modo geral e que não eram indispensáveis para constar de um trabalho sobre tal matéria. São exemplos: fertilização, incubação, injeção, ovulação, etc. Também as doenças genéticas foram descartadas, ou julgadas desnecessárias, uma vez que são em número bastante elevado e mereceriam um tratamento mais focado; sendo assim, foram descartados termos como: cistinúria, doença de Gaucher, galactosemia, leucodistrofia metacromática, etc.

Em Bioinformática, subárea da Genética Molecular, termos referentes a comandos ou aplicativos informáticos não foram privilegiados, mas sim aqueles referentes a técnicas e ferramentas utilizadas na manipulação do material genético, bem como bases de dados importantes na pesquisa. Assim, foram desconsiderados: DrawTree, hmmcalibrate, ProtDist, ProtPars, sreformat, etc.

Uma justificativa para a não-seleção desses termos citados também se insere no fator "objetivo" do trabalho. Não procuramos elaborar um trabalho exaustivo, mas, ao contrário, recolher os termos de fato mais utilizados especificamente pela Genética Molecular, visto que existem outros manuais/obras dicionarísticas que versam sobre 
Genética de maneira lato sensu.

Por conta do explicitado acima, e após análise e filtragem das unidades lexicais, obtivemos uma lista contendo 960 termos, os quais foram submetidos à análise morfossintática e organizados hierarquicamente em uma estrutura conceitual, de que trataremos nos capítulos subseqüentes.

\subsection{Processos de inovação lexical: uma análise baseada no corpus da Genética Molecular}

O estudo do léxico, e conseqüentemente dos processos de inovação e/ou renovação lexical, envolve um conhecimento bastante abrangente da língua, já que, em tais processos, interagem diversos componentes da gramática.

Segundo Rio-Torto (1998, p. 81):

Confinar a formação de palavras à morfologia derivacional e/ou à lexicologia não permite dar conta das diversas variáveis em jogo na produção lexical e de todas as dimensões que esta envolve. A estrutura de um produto derivacional não se esgota numa análise morfológica, ou sequer numa análise semântica que apenas tenha em conta a semântica dos seus constituintes e/ou processos constitutivos.

Ainda de acordo com a Autora, o processo de formação de palavras envolve:

a) a lexicologia, já que o léxico é a matéria-prima do qual se servem as línguas para dar origem a novos produtos lexicais;

b) a morfologia, na medida em que a produção de novas palavras implica a manifestação de estruturas lexicais como bases e afixos;

c) a morfossintaxe e a semântica, já que a formação de palavras também se define pela combinatória de elementos e estes, marcados por uma determinada categoria sintático-semântica, podem adquirir novos valores;

d) a fonologia, uma vez que, por suas potencialidades combinatórias, permite que as palavras operem também nesta dimensão;

e) e a pragmática, pois as palavras são usadas a serviço de estratégias interativas diversas. 
Dessa maneira, o estudo do léxico constitui-se como um espaço de interatividade entre diferentes setores da gramática de uma língua. Por esse motivo, julgou-se apropriado, para o estudo em questão, realizar-se uma descrição minuciosa dos processos de formação de palavras que apresentaram produtividade para o corpus terminológico da Genética Molecular, verificando-se se existem padrões de formação lexical para cada processo individualmente, e analisando-se sua recorrência.

Além disso, analisar o funcionamento dessas unidades terminológicas em contexto, buscando evidenciar as categorias gramaticais desempenhadas por tais termos, se faz bastante pertinente, uma vez que são os textos os responsáveis pela construção da identidade das unidades lexicais que conformam uma área de especialidade, constituindo o ambiente natural das terminologias.

Vale ressaltar aqui que a lista completa com todos os termos e suas respectivas análises conformacionais estará apresentada em 4.1.

A tipologia utilizada para classificar os processos de formação lexical é proveniente de Alves (2004), e é a seguinte:

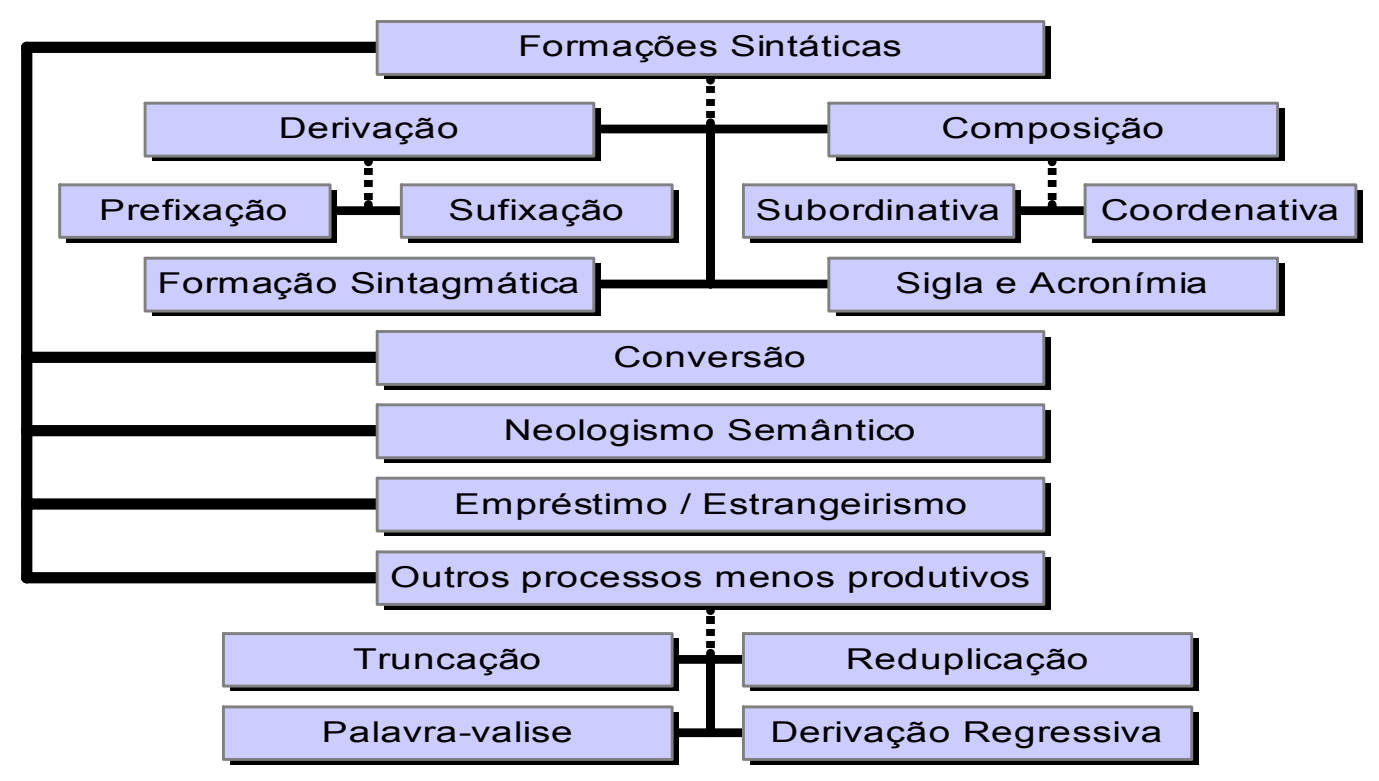

Figura 4. Processos de formação lexical

\subsubsection{As formações sintáticas}

As formações sintáticas são assim denominadas porque supõem a combinatória de 
elementos já existentes no sistema lingüístico português, e essa combinação não está circunscrita somente em nível lexical, mas também em nível frásico, já que "o acréscimo de sufixos pode alterar a classe da palavra-base; a composição tem caráter coordenativo e subordinativo; os integrantes da composição sintagmática e acronímica constituem componentes frásicos com valor de uma unidade lexical” (ALVES, 2004, p.14).

Dessa maneira, temos como processos sintáticos a derivação - prefixal e sufixal; a composição; a formação sintagmática; as siglas e os acrônimos, que serão tratados individualmente a seguir.

\subsubsection{Derivação}

\subsection{DERIVAÇÃO PREFIXAL}

Dá-se o processo de derivação prefixal à união de um prefixo a uma base. Neste trabalho, prefixo corresponde a uma "partícula independente ou não-independente que, anteposta a uma palavra-base, atribui-lhe uma idéia acessória e manifesta-se de maneira recorrente, em formações em série" (ALVES, 2004, p. 15).

Quando tratamos de prefixação, inevitavelmente esbarramos na questão das "fronteiras" entre a derivação (prefixal e sufixal) e a composição, já que alguns formantes, considerados em obras de referência ${ }^{16}$ como elementos de composição, atualmente vêm sendo classificados como prefixos. Este fato se justifica por sua recorrência não só na conformação das áreas de especialidade como também na criação lexical (neologia) da língua geral.

Como uma tentativa de desambigüização de tais conceitos, alguns autores, dentre os quais se pode citar Sandmann (1989) e os gramáticos Cunha e Cintra (1985), utilizam os termos prefixóide ou pseudoprefixo para designar esse tipo de formante fronteiriço.

Cunha e Cintra (1985, p.111) consideram pseudoprefixos ou prefixóides os radicais latinos e gregos que adquiriram sentido especial nas línguas modernas, introduzidos na língua em razão das necessidades técnico-científicas e que assumem o sentido global dos vocábulos de que antes eram elementos componentes.

Sandmann, por sua vez, entende por prefixóides os elementos que se prestam à 
formação de palavras em série, embora apresentem um correspondente que ocorre livremente na frase. Ressalta, porém, que "quando elementos de origem estrangeira, como, por exemplo, auto- e pseudo-, se integram no português e se prestam para formações em série, eles fazem parte dos prefixos e não são considerados radicais estrangeiros presos" (SANDMANN, 1989, p.13-14).

De acordo com Herculano de Carvalho ${ }^{17}$ (1974, apud CUNHA; CINTRA, 1985, p.112) os prefixóides apresentam baixa produtividade em relação aos prefixos e caracterizam-se por possuírem uma significação relativamente restrita, de modo que se possa remetê-la a um conceito mais amplo, a um sintagma, por exemplo.

Com o intuito de esclarecer-nos sobre tal temática, Alves (2000) traz, em sua tese de livre docência, uma minuciosa revisão histórica sobre a caracterização e gramaticalização dos elementos prefixais, analisando, nesta ocasião, aspectos sintáticos, semânticos e morfológicos fundamentais à plena compreensão dos fatos concernentes a essa matéria.

Segundo a Autora, alguns destes formantes caracterizados como prefixóides ou pseudoprefixos "têm passado à língua geral, formando unidades lexicais que não se vinculam a nenhuma área específica", o que termina por não justificar o uso de tais denominações, mas, ao contrário, estender a tais formantes a designação de prefixo, de maneira irrestrita.

Deste modo, no presente trabalho classificaremos como prefixos as partículas que conferem uma idéia acessória à palavra-base a qual antecedem, quando se prestam a formações em série.

A seguir, listamos os formantes prefixais encontrados em nosso corpus de pesquisa:

auto-: designativo de "por si próprio", forma substantivos derivados de substantivos como: autoduplicação, auto-radiograma, auto-replicação. No nosso corpus de pesquisa, tal formante apresentou somente uma ocorrência de formação com base presa - $\underline{\text { autossomo }}$ (auto- + -somo) -, já que em todos os outros casos uniu-se a elementos de base livre.

bio-: designativo de "vida, biológico", apresenta grande produtividade para as biociências, formando substantivos derivados de adjetivos como biobalística, bioenergética e derivados

\footnotetext{
${ }^{16}$ Trata-se do Dicionário Houaiss da Língua Portuguesa, Dicionário Aurélio e gramáticas tradicionais.

${ }^{17}$ CARVALHO, J.G.H. Teoria da linguagem. Coimbra: Atlântida Editora, 1974.
} 


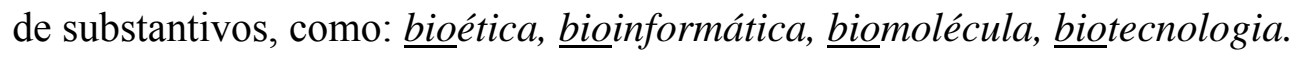

mult(i)-: designativo de abundância ou grande quantidade, também forma substantivos a partir de substantivos: multipotência.

plur(i)-: designativo de quantidade e intensidade, é responsável pela formação de substantivos a partir de substantivos: pluripotência.

No corpus analisado, tal formante concorre com o apresentado anteriormente (mult(i)-), podendo ser, para este caso especificamente, considerado como variante.

mini-: designativo de tamanho reduzido ou intensidade decrescente, tal formante gera também substantivos derivados de substantivos, tais como: minisseqüência, minisseqüenciamento, ainda que esteja evidente a origem também derivada do segundo exemplo (seqüência --- seqüenciamento).

macr(o)-: designativo de comprimento e longitude, forma substantivos derivados de substantivos, a exemplo de: $\underline{\text { macromolécula. }}$

trans-: designativo de espacialidade, o prefixo forma substantivos deverbais ou dessubstantivos; no corpus, apareceram formações apenas derivadas de substantivos: transdiferenciação, transgene, transgênese.

mega-: designativo de intensidade reforçativa, forma substantivos derivados de substantivo, aparecendo exemplos como: megabase.

di-: designativo de duplicidade, o prefixo forma, geralmente, substantivos derivados de substantivo, como o que ocorreu no corpus: $\underline{\text { dimorfismo. }}$

co-: apresentado idéia de companhia, o prefixo também forma substantivos a partir de substantivos; aparece em $\underline{\text { co-fator. }}$ 
centi-: equivalente a "centésima parte", forma substantivos a partir de substantivos, e ocorre em formações como centimorgan, de produtividade baixa para o corpus em análise.

A seguir, o gráfico resume e apresenta a produtividade dos prefixos que ocorreram no corpus:

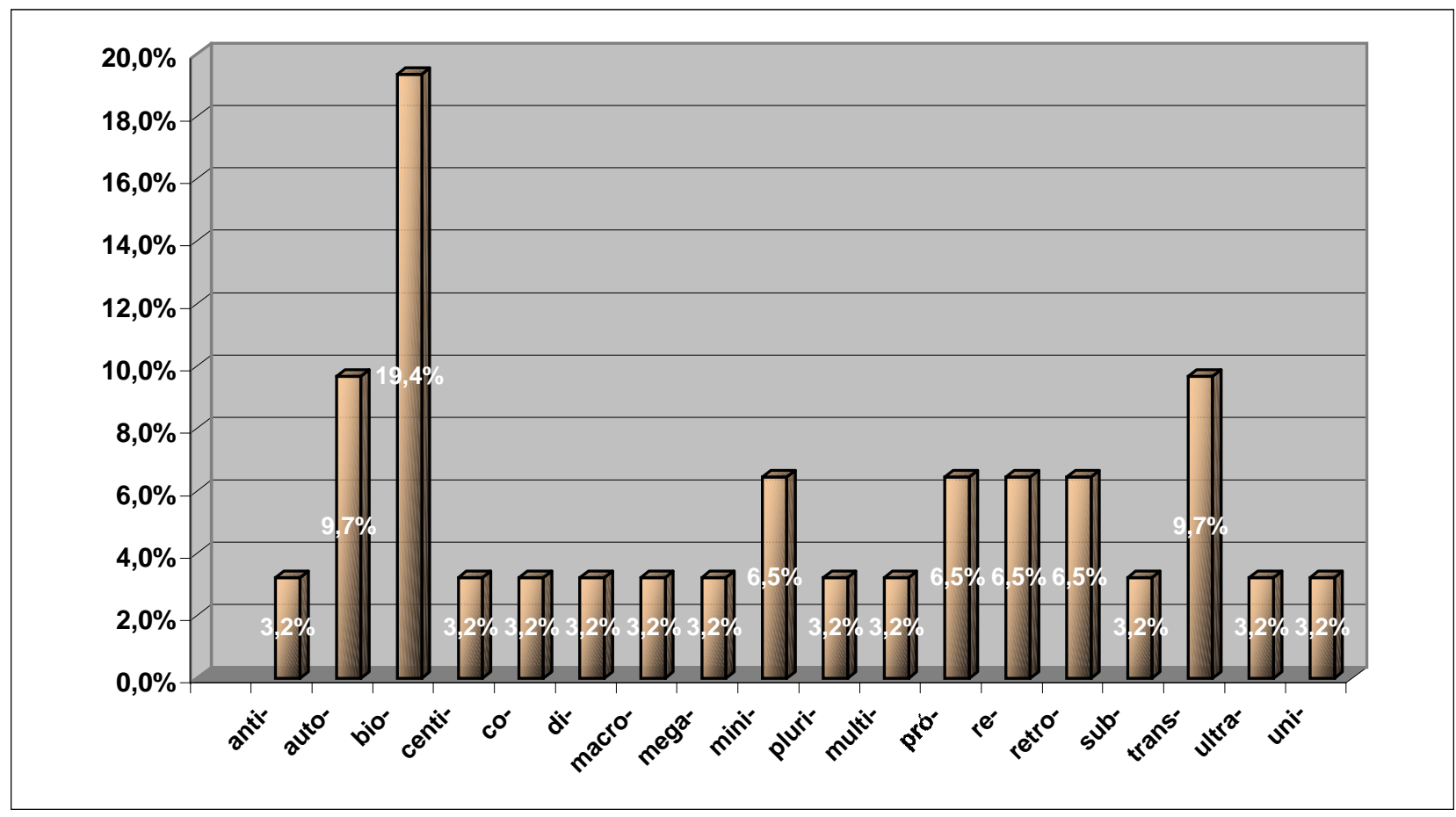

Gráfico 1. Produtividade dos prefixos

\subsection{DERIVAÇÃO SUFIXAL}

Neste tipo de derivação, o sufixo, elemento de caráter não-autônomo e recorrente, atribui à palavra-base à qual se associa uma idéia acessória, geralmente lhe modificando a classe gramatical.

Analogamente aos prefixos, as formações sufixais também apresentam certa controvérsia quanto a seus formantes classificarem-se como elementos de composição ou como sufixos propriamente ditos, porém, de forma menos acentuada e polêmica.

Sandmann (1989, p.115) apresenta o termo sufixóide, que classifica como um elemento que se presta a formações de palavras em série; porém, podem manifestar-se 
livremente ou anexadas a palavras complexas. O Autor exemplifica sua teoria como a palavra jazzmania, considerando mania como um sufixóide.

Ainda que a caracterização de prefixóides e sufixóides seja um tanto distinta, procedemos, neste caso, do mesmo modo como fizemos com os prefixos, considerando os sufixos como elementos que, em formações em série, atribuem, à palavra-base à qual se associam, uma idéia complementar. Assim, o termo sufixo também está sendo empregado de maneira irrestrita.

Vale ressaltar que a grande maioria das formações sufixais que ocorreram no corpus formou substantivos deverbais. Vejamos alguns exemplos extraídos do corpus:

-ção: designativo de ação/processo, forma, freqüentemente, substantivos deverbais (da primeira conjugação) como: acetilação, amplificação, anotação, centrifugação; e (com verbos em-izar): circularização.

-mento: designativo de ação/processo, forma, freqüentemente, substantivos deverbais (derivados de verbos da primeira conjugação) como: alinhamento, bandeamento, ordenamento, plaqueamento.

-agem: designativo de ação/processo, pode unir-se a verbos (da primeira conjugação) ou substantivos: clivagem, clonagem, genotipagem, linhagem, triagem.

-ência: designativo de qualidade/estado, ocorre sob forma erudita, porém pode aparecer sob a forma -ância e -ança. Aparece geralmente ligado a verbos da segunda e terceira conjugação, alterando, neste último caso, a vogal temática de /i/ para /e/, formando substantivos. São exemplos: fluorescência, transferência.

-dor: sufixo agentivo, forma deverbais (de primeira conjugação), aparecendo em formações como: carreador, marcador.

-eiro: formador de adjetivos derivados de substantivos, aparece em vocábulos como hospedeiro. Vale ressaltar que tal sufixo é designativo de "recipiente, receptáculo" e possui 
baixa produtividade para o corpus.

-ase: é considerado sufixo desde que empregado nas áreas química ou biológica, já que sua classificação tradicional é de "terminação"; vem sendo empregado para designar enzimas: ligase, nuclease.

-ico: sufixo denotativo de "pertinência, relação, referência, participação", forma geralmente adjetivos, mas também ocorre como substantivo. No corpus, dois adjetivos são resultado desse processo: quimioterápico, trangênico.

-(i)dade: formador de substantivo a partir de adjetivo, designa "qualidade, caráter, atributo", e aparece nas formas: radioatividade, similaridade.

-ose: designativo de "processo", forma substantivos como: mitose, meiose.

-or: sufixo agentivo, forma substantivos deverbais ou dessubstantivais; em nosso corpus registramos promotor, apresentando irregularidade de base.

-ídeo: designativo de "derivados de, ou relacionados a uma classe de substâncias", tal sufixo aparece em formações como: cosmídeo, nucleotídeo, plasmídeo. Cabe ressaltar que tal formante ocorreu somente com bases presas, diferentemente dos outros formantes sufixais.

-oma: originalmente elemento de composição, sua recorrência para as ciências médicas acabou por lhe atribuir o estatuto de sufixo (atestado por Houaiss). Designa "tumores", e, por extensão, "processos patológicos histológicos"; porém, em nosso caso especificamente, "nome de conjuntos ou sistemas": genoma, transcriptoma.

Abaixo, o gráfico resume e apresenta a produtividade dos sufixos encontrados no corpus: 


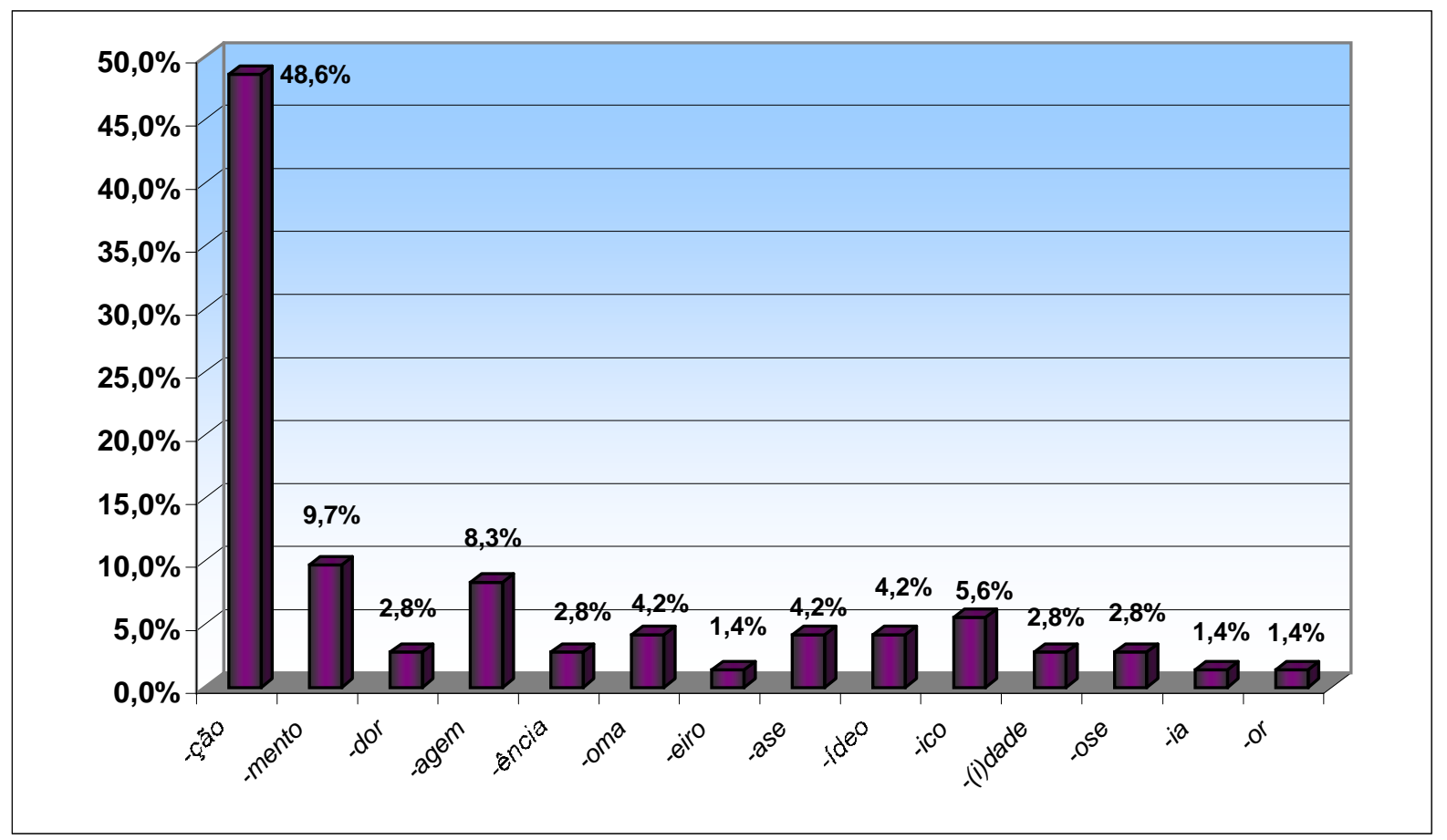

Gráfico 2. Produtividade dos sufixos

\subsubsection{Composição}

Processa-se a composição pela justaposição de bases autônomas e não-autônomas, podendo essa justaposição revelar caráter subordinativo ou coordenativo.

As composições subordinativas relacionam substantivos, verbo e substantivo, adjetivo e substantivo, e caracterizam-se por uma relação determinante/determinado ou determinado/determinante entre seus componentes, podendo ser compostas entre bases livres e bases presas, formando substantivos. Assim, o elemento determinado constitui o elemento genérico, ao qual o determinante acrescenta uma especificidade.

Já as composições coordenativas são aquelas em que o processo de justaposição se dá entre elementos de mesma distribuição, podendo ser formados com substantivos, adjetivos ou ainda outra classe gramatical.

Em nosso corpus de pesquisa, a composição por subordinação revelou-se predominante, e foram encontrados os seguintes tipos de formações: base presa + base 
livre, base presa + base presa e base livre + base livre.

A seguir, alguns exemplos extraídos do corpus:

base presa + base livre:

adenovírus (s.m.) - composição por subordinação (aden(o)- + vírus)

radioimunoensaio (s.m.) - composição por subordinação (radi(o)- + imun(i/o)- + ensaio)

xenotransplante (s.m.) - composição por subordinação (xen(o)- + transplante)

\section{base presa + base presa:}

Como é comum em casos de justaposições de bases presas, em determinadas ocasiões se faz imprescindível uma vogal ou consoante de ligação, para que não ocorra uma quebra fonológica, como é o caso em nucleotídeo.

citometria (s.f.) - composição por subordinação (cit(o) - + -metria)

cladograma (s.m.) - composição por subordinação (clad(o)- + -grama)

mutágeno (s.m.) - composição por subordinação (mut- + -geno $)^{18}$

\section{base livre + base livre:}

Deve-se observar que, dentre as formações com bases livres, podem ocorrer junções entre substantivos ou entre substantivo e adjetivo, sendo que esta é de ocorrência baixa dentre as composições analisadas no presente trabalho.

célula-tronco (CT) (s.f.) - composição por subordinação $(S+S)$

molécula-vetor (s.f.) - composição por subordinação $(S+S)$

vetor-livre (s.m.) - composição por subordinação ( $S+A d j)$

Mais recorrente no processo da composição são as formações base presa + base livre e base presa + base presa, constituídas, quase em sua totalidade, por formantes grecolatinos. E então, mais uma vez, estamos de acordo com as proposições de Cabré (1999, p. 25), quando se refere à produtividade dos formantes cultos para a terminologia. Em suas

${ }^{18}$ De análise controversa, o termo mutágeno é passível de duas interpretações, no que concerne à sua conformação: mutação + -geno, portanto, base livre + base presa, ou mut- + -geno, base livre + base livre. Ainda que o Dicionário Houaiss traga a primeira classificação, acreditamos ser mais conveniente o segundo tipo. 
palavras:

[...] en terminología, las unidades compuestas por formantes cultos y las construcciones sintagmáticas fijas suelen tener un rendimiento mucho más elevado que en lexicología general.

\subsubsection{Formação sintagmática}

De acordo com Alves (2004, p.50), "processa-se a composição sintagmática quando os membros integrantes de um elemento frasal encontram-se numa íntima relação sintática, tanto morfológica quanto semanticamente, de forma a constituírem uma única unidade léxica”.

Existe, porém, grande dificuldade de reconhecimento de terminologias que ainda não se encontram num grau de lexicalização muito alto, ou que não condizem com os critérios tidos como índices de lexicalização, já apontados anteriormente (ver item 3.1.). Nestes casos, somente o aval do especialista pode garantir a presença de um termo.

Ainda que de difícil segmentação, as formações sintagmáticas podem ocorrer de diversas maneiras, porém a ordem determinado-determinante é quase sempre mantida, mesmo que esta venha antecedida por uma preposição (ou por mais de uma, como veremos nos exemplos). Em nosso corpus de análise, ocorreram os seguintes tipos de formações sintagmáticas, que foram reunidas em três grandes grupos: $\mathbf{S}+\mathbf{A d j} ., \mathbf{S}+\mathbf{S P}$ e $\mathbf{S}+\mathbf{A d j}$. + SP (ver Lista de Abreviaturas):

S + Adj.: clonagem posicional (s.f.)

S + Adj. + Adj.: cromossomo artificial humano (HAC) (s.m.)

S + SAdj.: abordagem shotgun (s.f.); alinhamento perfil-perfil (s.m.)

S(composto) + Adj.: fago-vetor unifilamentar (s.m.)

S(composto) + Ad. + Adj.: célula-tronco embrionária recombinante (s.f.)

S (sigla) + Adj.: DNA plasmidial (s.m.)

S(sigla) + SAdj.: DNA minissatélite (s.m.) 
Vale ressaltar algumas particularidades encontradas nas formações acima. Os sintagmas adjetivais - unidades lexicais em função adjetival - são formados recorrentemente por um termo estrangeiro (abordagem shotgun) ou por um composto (alinhamento perfil-perfil). As siglas, que funcionam como substantivo, geralmente são de origem estrangeira, como o caso de DNA, RNA, etc. Ainda que exista um termo vernáculo correspondente, no uso ele não é privilegiado, motivo pelo qual aqui utilizamos também o estrangeiro.

S + SP: vetor de clonagem (s.m.)

S(composto) + SP: célula-tronco de teratoma (CTt) (s.f.)

S + SP (S + SP): eletroforese em gel de agarose (s.f.)

S + SP (S + Adj.): tecnologia do DNA recombinante (s.f.)

S + SP (S + SP + Adj.): alinhamento de pares de seqüência global (s.m.)

S + SP + (S + SP (S + Adj.)): eletroforese em gel de poliacrilamida desnaturante (s.f.)

Neste grupo também se percebe a presença de sigla estrangeira (DNA) funcionando como substantivo.

S + Adj. + SP: matriz aberta de leitura (s.f.)

S + Adj + SP (S + SP): análise serial da expressão do gene (s.f.)

S + Adj. +SP (S(composto) +Adj.): terapia celular com células-tronco embrionárias (s.f.)

\section{Outras formações:}

matriz de pontuação especifica da posição (PSSM) (s.f.) - ( S + SP (S + Adj. + SP))

Comissão Técnica Nacional de Biossegurança (CTNBio) (s.f.) - (S + Adj. + Adj. + SP)

eletroforese em gel com gradiente de desnaturação (s.f.) - (S + SP ( S + SP ( S + SP))

Percebe-se, analisando-se o modo de constituição dessas formações, que há uma grande variedade de sintagmas adjetivais, ou seja, substantivos e siglas (tanto vernáculas quanto estrangeiras) funcionando como adjetivos; também a presença marcante de estrangeirismos, marcados em itálico, o que pode ser explicado pelo grande avanço em pesquisas na área de Genética em países de língua inglesa. 
Porém, as formações mais produtivas são as construções vernaculares formadas por substantivo + adjetivo e substantivo + sintagma preposicional (preposição + substantivo), o que denota a especialização/desenvolvimento de pesquisas em Genética Molecular no Brasil, já que a língua é capaz de expressar conhecimentos de uma área especializada, não originalmente brasileira, com elementos próprios, na maioria dos casos. Assim, o repertório léxico de uma disciplina acaba por expressar o grau de desenvolvimento de uma área de especialidade, em uma dada comunidade, por meio de sua constituição morfossintática.

Uma lista, contendo todos os termos compostos por formação sintagmática, e suas respectivas análises, encontra-se em 3.3.

\subsubsection{Sigla e acronímia}

Tipo especial de formação sintagmática, a sigla e a acronímia são resultantes de um processo de economia discursiva, facilitando e tornando eficaz o processo de comunicação. As formações por sigla encontradas no corpus correspondem, em sua grande maioria, a reduções de termos estrangeiros. Ainda que haja um equivalente vernáculo (DNA/ADN RNA/ARN), estas formas não são privilegiadas pragmaticamente, motivo pelo qual as conservamos também para esta pesquisa.

C/C++ (s.f.) (linguagem computacional)

ORESTES (s.m.) - ORF ESTs / Open reading frames EST sequences

$R H$ (s.m.) - rhesus factor

RNA (s.m.) - ácido ribonucléico / ribonucleic acid

DNA (s.m.) - ácido desoxirribonucléico / deoxyribonucleic acid

\subsubsection{Empréstimo / Estrangeirismo}

Pertencente a outro sistema lingüístico, o termo estrangeiro é empregado para cobrir uma lacuna de denominação em língua vernácula, o que vem refletir a origem do desenvolvimento tecnológico e científico de um domínio de especialidade.

$\mathrm{Na}$ terminologia da Genética Molecular, os termos estrangeiros ocupam a quarta posição em relação à produtividade de formação de palavras para o nosso corpus, uma 
posição relativamente alta em comparação com algumas formações vernáculas.

Cabe aqui fazer uma diferenciação entre estrangeirismo e empréstimo. Segundo Alves (2004, p.72), o elemento estrangeiro é aquele percebido como externo ao sistema vernáculo, sendo empregado ocasionalmente. O empréstimo, todavia, se caracteriza pela integração desse elemento à língua receptora, geralmente por meio de uma adaptação gráfica, morfológica ou semântica.

Nas linguagens técnicas, é bastante comum o emprego de termos estrangeiros, o que vem a refletir, como dito anteriormente, a origem do desenvolvimento em pesquisas na área em questão. No nosso caso, denominaremos estrangeirismos os termos oriundos de outro sistema lingüístico em geral, ainda que tenham predominância inglesa.

Abaixo, listamos alguns exemplos que ocorreram no corpus:

regulon (s.m.)

basecalling (s.m.)

b-value (s.m.)

fluorescence activated cell sorter (FACs) (s.f.)

genome-wide scan (s.m.)

Genome Survey Sequence (GSS) (s.f.)

Multiple EM (Expectation Maximization) for Motif Elicitation (MEME) (s.m.)

National Center for Biotecnology Information (NCBI) (s.m.)

\subsubsection{Neologismo semântico}

Definido como uma alteração dos semas existentes em uma unidade léxica, sem, todavia, acarretar-lhe uma mudança formal, os neologismos semânticos aparecem em número bastante reduzido no corpus, representando apenas $0,4 \%$ das formações.

Abaixo estão os representantes desse tipo de formação, seguidos dos contextos de onde foram extraídos:

buraco (s.m.) - "Os buracos (gaps) devem aparecer na seqüência, para facilitar melhores combinações?” (GIBAS, C., JAMBECK, P. 2001, p. 179)

motivo (s.m.) - "Um motivo é uma seqüência de aminoácidos que define uma subestrutura 
em uma proteína que pode ser relacionada à função ou estabilidade estrutural” (GIBAS, C., JAMBECK, P. 2001, p. 34)

biblioteca (s.f.) - "Uma importante vantagem dessa estratégia é que a divisão seqüencial da bilioteca em sub-bibliotecas cada vez menores pode conduzir à identificação dos antígenos protetores." (Genômica, 2004, p. 505)

\subsubsection{Outros processos}

\subsubsection{Formação simples}

São as formações vernáculas, simples. Cabe salientar que as formações provenientes do grego ou latim científico foram classificadas como termos de formação simples.

Formam um total de 36 ocorrências, representando 3,8 \% do corpus.

A seguir, alguns exemplos:

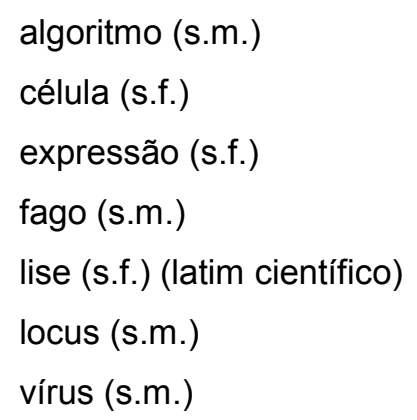

\subsubsection{Eponímia}

Representando apenas um caso, excluindo-se aqui a ocorrência de epônimos em formações sintagmáticas, a eponímia caracteriza-se pela atribuição de nome próprio a objetos, técnicas, etc.

Nosso exemplo:

angstron (s.m.) - epônimo de Anders J. Ångström (†1874, físico sueco)

3.2.4.3. Derivação regressiva 
A derivação regressiva é um processo de formação lexical bastante controverso.

A maioria dos autores considera como mais comum e produtiva a derivação regressiva formadora de substantivos deverbais, suprimindo-se a desinência e acrescentando-se ao radical as vogais temáticas - $a$, -e ou -o. É o caso, por exemplo, de:

análise (s.f.) - analisar + -e = análise

transplante (s.m.) - transplantar $+-e=$ transplante

consulta (s.f.) - consultar $+-a=$ consulta

O gráfico seguinte apresenta a produtividade dos processos de formação lexical encontrados no corpus de trabalho:

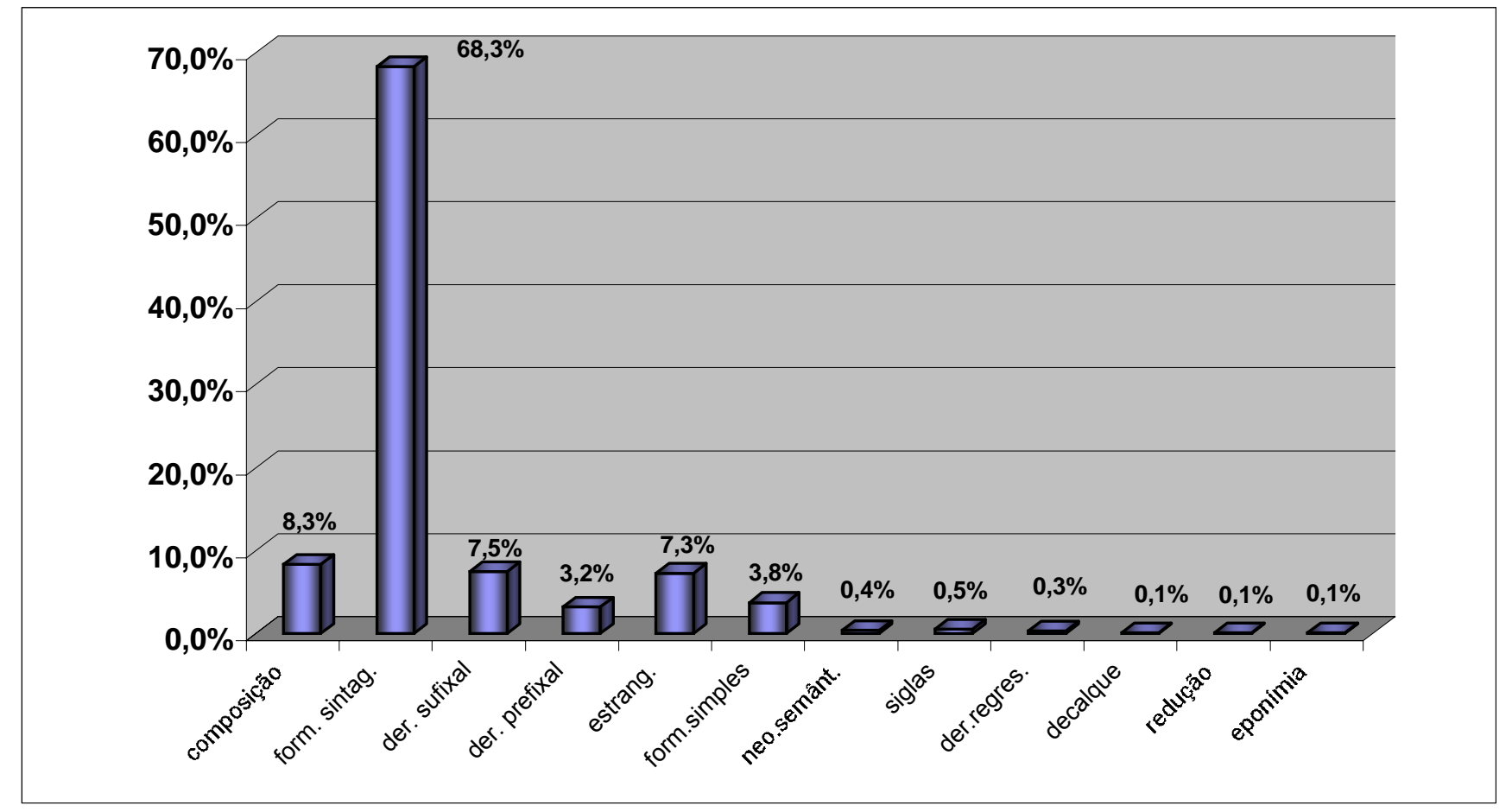

Gráfico 3. Produtividade dos processos de formação de palavras

O que se depreende de toda essa análise é que a descrição dos formantes das unidades terminológicas, e, por conseguinte, a análise de seu funcionamento em situação especializada, é de grande valia para o avanço dos estudos em Terminologia. Isso porque pode proporcionar um mais profundo conhecimento do modus operandi dos sistemas 
lingüísticos, fundamental para expressar as ciências e técnicas, mas também para a renovação do léxico geral.

Além disso, tal análise permite avaliar os avanços técnico-científicos dos quais participa o País, e assim analisar a evolução social e cultural de uma sociedade, que apenas adquire um determinado poderio quando pode expressar-se, ou quando é capaz de obter e repassar conhecimentos utilizando-se de sua língua materna.

\subsection{Organização semântica do vocabulário da Genética Molecular}

\subsubsection{Campo lexical, campo conceptual e campo semântico}

O vocabulário, em um estado lingüístico sincrônico, encontra-se articulado semanticamente, ou seja, as palavras apresentam-se relacionadas umas com as outras por meio de seus conteúdos, por sua carga sêmica. Assim, os vocabulários são passíveis de organizarem-se em campos lexicais, lugar onde se evidenciam algumas relações de significação. Essas relações podem se dar de diferentes maneiras: hierarquicamente (superordenação/subordinação) ou coordenadamente, e é essa distribuição que delimita e confere valor às palavras, individualizando-as umas das outras.

Ipsen $^{19}$ (apud GECKLER, 1976, p.102), um dos primeiros teóricos a tratar a questão da estruturação semântica da língua, afirma que:

[...]las palabras autóctonas no están nunca solas en una lengua, sino que se encuentran reunidas en grupos semánticos; con ello no hacemos referencia a un grupo etimológico, aún menos a palabras reunidas en torno a supuestas 'raíces', sino a aquellas cuyo contenido semántico objetivo se relaciona con otros contenidos semánticos. Pero esta relación no está pensada como si las palabras estuviesen alineadas en una serie asociativa, sino de tal suerte que todo el grupo forme un "campo semántico" estructurado en sí mismo; como en un mosaico, una palabra se une aquí a la otra, cada una limitada de diferente manera, pero de modo que los contornos queden acoplados y todas juntas queden englobadas en una unidad semántica de orden superior, sin caer en una obscura abstracción.

Em seguida, Trier $^{20}$ (apud GECKLER, 1976, p.119) vem a corroborar os estudos de

\footnotetext{
${ }^{19}$ IPSEN, G. Der Alte Orient und die Indogermanen. Stand and Aufgaben der Sprachwissenschaft. Festschrift für Wilhelm Streitberg, Heidelberg, 1924.

${ }^{20}$ TRIER , J. Der deutsche Wortschatz im Sinnberzik des Verstandes. Die Geschichte eines sprachlichen Felds, tomo I: Von den Anfängen bis zum Beginn des 13. Heidelberg: Jahrunderts, 1931.
} 
Ipsen:

El significado de cada palabra depende del significado de sus vecinas conceptuales. Todas se unen en la tarea de introducir límites diferenciadores en el boque del contenido inarticulado de la conciencia, de organizarlo y hacerlo inteligible conceptualmente [...] El valor de la palabra se reconoce sólo si se lo delimita frente al valor de las palabras que le son vecinas y que se le oponen. Sólo tiene sentido como parte del todo, pues sólo en el campo hay significación.

Posteriormente a Trier, Coseriu (apud Geckler, 1976, p.240) também se dedica ao estudo dos campos léxicos, porém baseado em procedimentos lingüísticos para a organização dessa estruturação semântica, já que em Trier, assim como em Ipsen, ainda existia uma base intuitiva para tal classificação. Sua definição de campo léxico:

Un campo léxico es, desde el punto de vista estructural, un paradigma léxico que se origina de la distribución de un contínuo de contenido léxico en diferentes unidades, dadas en la lengua como palabras, que está recíprocamente en oposición inmediata mediante rasgos distintivos de contenido simples.

Uma distinção bastante relevante refere-se aos conceitos de campo lexical e campo conceptual. É recorrente, na literatura, o emprego de ambas as formas, muitas vezes utilizadas com o mesmo significado. Neste sentido, Coseriu ${ }^{21}$ (apud GECKLER, 1976, p.240) coloca a seguinte afirmação - note-se a relação de inclusão que existe entre os dois conceitos:

Los campos léxicos no son idénticos a los campos conceptuales. Todo campo léxico es un campo conceptual, pero no todo campo conceptual tiene que ser un campo léxico, pues un campo conceptual puede ser también un campo terminológico. Todo lexema corresponde a un concepto, pero no todo concepto está reflejado necesariamente sólo por un lexema. El concepto puede expresarse también mediante un grupo que abarque varias palabras [...].

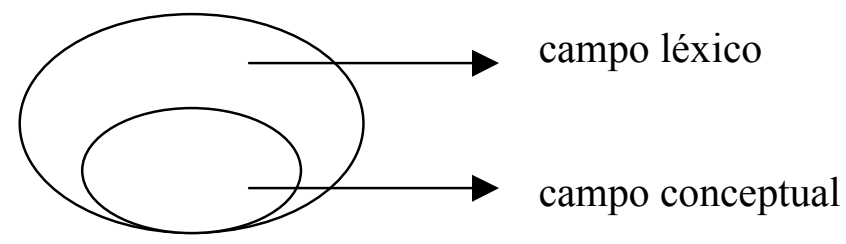

${ }^{21}$ COSERIU, E. Pour une sémantique diachronique structurale. Travaux de linguistique et de littérature II, 1, 1964. 
Portanto, um campo léxico distingue-se de um campo conceptual na medida em que é de caráter mais abrangente, já que se baseia paradigmaticamente em diferenças semânticas entre seus membros constituintes, não necessariamente relacionados a uma realidade extralingüística. Por exemplo, um campo léxico pode ser apresentado como "bonito-feio", o campo léxico da beleza.

Uma outra distinção conceitual muito importante refere-se à concepção de campo conceptual e campo semântico. Quando se fala em campo semântico, pensa-se em uma descrição polissêmica de determinada palavra ou termo. Segundo Dubois (1989, p.532,533), “chama-se campo semântico a área coberta, no domínio da significação, por uma palavra ou um grupo de palavras da língua". Neste sentido, o campo semântico da palavra mesa, poderia ser constituído de mesa de trabalho, mesa de refeições, mesaredonda, mesa de eleição, mesa da Assembléia, mesa de operação, pôr as cartas na mesa, roupa de cama e mesa, etc. Já o campo conceptual de mesa poderia ser descrito do ponto de vista das relações existentes entre este e outros designativos de móveis de casa, de escritório, etc.

Portanto, um campo conceptual pode ser definido como um "conjunto de conceitos ligados entre si e que podem ser agrupados em torno de um conceito-chave" (BoutinQuesnel $^{22}$ apud BARROS, 2004, p.112).

Ainda segundo o Dicionário de Termos Lingüísticos ${ }^{23}$ - em formato eletrônico e elaborado pela Associação de Informação Terminológica de Portugal -, campo conceptual e campo lexical são apresentados da seguinte maneira:

\section{campo conceptual}

Termos relacionados: campo lexical; campo semântico

Classificação: lexicologia; semântica

Definição: Termo que refere a organização estrutural de uma área conceptual por um sistema lingüístico particular, partindo do pressuposto de que se encontra uma substância de significado não estruturada subjacente ao vocabulário de todas as línguas. Distingue-se de campo

\footnotetext{
${ }^{22}$ BOUTIN-QUESNEL, R. et al. Vocabulaire systématique de la terminologie. Québec, Publications du Québec, 1985 (Cahiers de l'Office de la Langue Française).

${ }^{23}$ Disponível em $<$ http://www.ait.pt/index 2 .htm $>$
} 
lexical, que designa especificamente o conjunto de lexemas de que uma língua se serve para, em função das relações de sentido existentes entre os mesmos, abranger e estruturar uma área conceptual. Assim, é possível falar no campo conceptual das cores, que lingüisticamente se realiza num campo lexical que inclui lexemas como "preto", "branco", "azul", etc.

\section{campo lexical}

Termos relacionados: campo conceptual; campo semântico; teoria de campo

Classificação: semântica; lexicologia

Definição: Refere o conjunto de lexemas que, organizados em função das relações de sentido existentes entre si, abrangem uma determinada área de significação, estruturada num campo conceptual. Exemplo: o campo conceptual das relações de parentesco é lingüisticamente veiculado por um campo lexical que inclui lexemas como "pai", "mãe", "filho", etc.

\subsubsection{As relações conceptuais}

A partir do explicitado acima, organizar e estruturar o léxico se faz muito pertinente quando se trabalha com uma área de especialidade. A Terminologia vem apresentando avanços consideráveis em suas técnicas e métodos de pesquisa pela organização de estruturas conceptuais de suas áreas e subáreas de estudo.

De acordo com a TGT, de Eugen Wüster, a Terminologia se ocupa dos conceitos. Estes se relacionam mutuamente dentro de um mesmo domínio de conhecimento e são passíveis de serem organizados em uma estrutura, formando um conjunto sistematizado.

As relações que podem se dar entre esses conceitos, segundo Wüster, são de dois tipos: relações lógicas (gênero-espécie) e ontológicas (todo-parte), que podem ser resumidas como sendo relações hierárquicas.

Segundo o Autor, os conceitos compartilham, em sua intensão, uma determinada carga sêmica, e este compartilhamento pode ser identificado de duas maneiras: por subordinação lógica ou coordenação lógica. Por subordinação lógica entende-se, de acordo com Wüster (1998, p.41):

Si uno de los conceptos posee todas las características del otro, y además, como mínimo una característica adicional, se dice que es un concepto subordinado del otro; el otro se convierte en su concepto genérico. Esta relación se llama subordinación lógica (si se considera que la relación que une los dos conceptos viene de arriba) y superordenación lógica (si se considera la misma relación desde abajo). Manzana es un concepto subordinado de fruta.

já por coordenação lógica, Wüster ( 1998, p.41) declara que: 
Muchas veces, cada uno de los conceptos tiene además de la intención común, por lo menos, una característica suplementaria que los distingue. Si las características distintivas forman parte de la misma categoría de características, dicho de otra manera, si ambas tienen el mismo genérico, entonces se habla de coordinación lógica. Existe una coordinación lógica entre los conceptos manzana y pera.

Depois de Wüster, outros autores se dedicaram ao estudo das relações de significação entre conceitos, sendo ampliada a classificação originalmente criada por ele. Arntz e Pitch (1989 apud ALMEIDA, 2000, p.121) acrescentaram às relações hierárquicas também as não-hierárquicas, como as relações causais, por exemplo. Segue o esquema proposto pelos Autores:

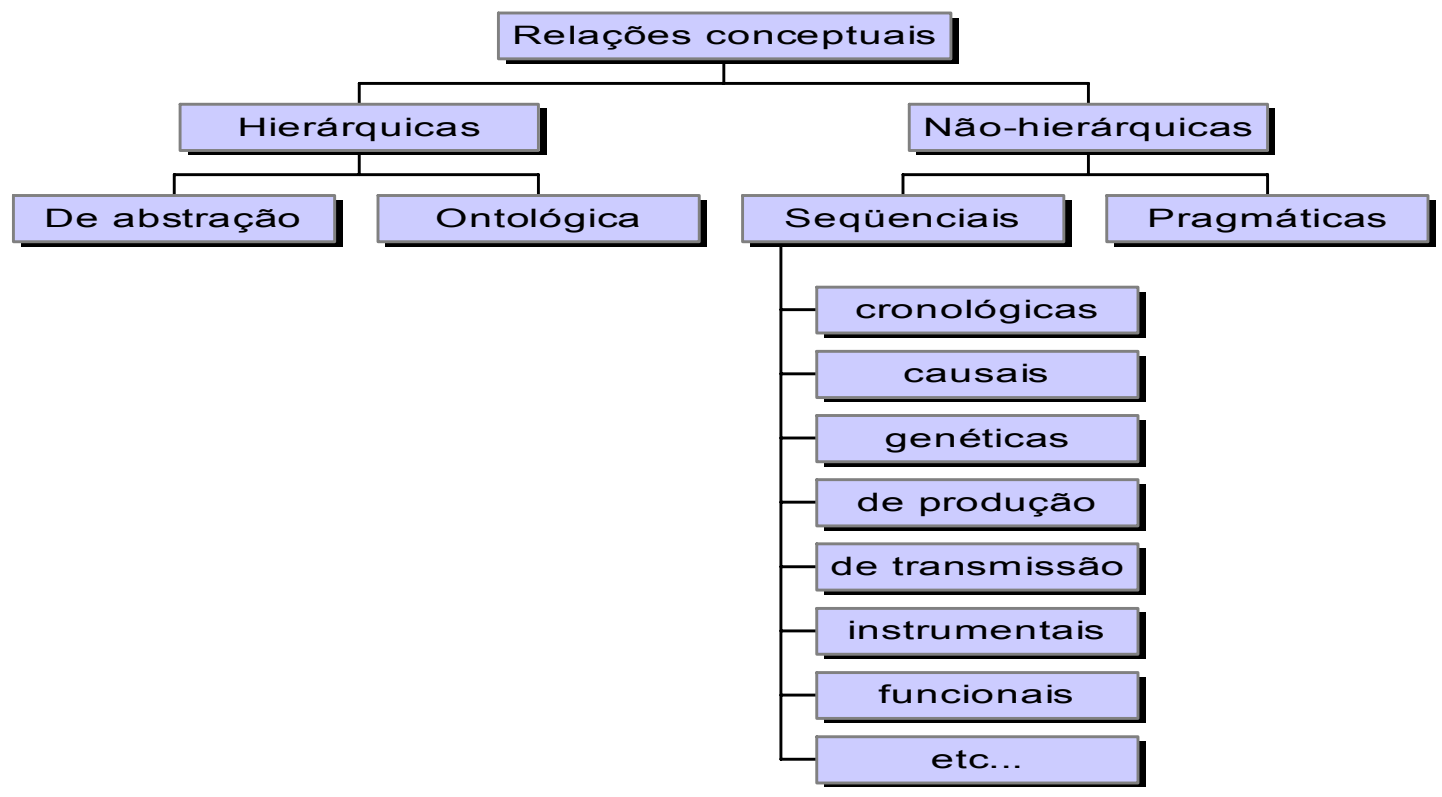

Figura 5. Relações conceptuais

Sager (1993, p. 29) vem a corroborar tais idéias, afirmando que:

It is now recognized that for practical applications, virtually any number or type of conceptual relationship can be established and declared required by a particular need; e.g. an object can be related to its geographical origin, its material substance, its method of production, its use and function, etc. The size of conceptual fields and the complexity of the relationships to be declared within it, is a matter of the practical assessment of the purpose for each conceptual analysis is undertaken; in other words, terminology relates terms to concepts (and not vice versa) and is therefore not concerned with absolute conceptual systems but only with systems created for the specific purpose of assisting communication. 
Assim, o Autor (1993, p.35) propõe uma lista com as possíveis relações que se podem estabelecer entre os conceitos:

$\begin{array}{ll}- & \text { causa-efeito } \\ \text { - } & \text { fenômeno-medida } \\ \text { - } & \text { material-estado } \\ \text { - } & \text { material-produto } \\ \text { - } & \text { material-propriedade } \\ \text { - } & \text { objeto-característica } \\ \text { - } & \text { objeto-forma } \\ \text { - } & \text { objeto-lugar } \\ & \text { objeto-material }\end{array}$

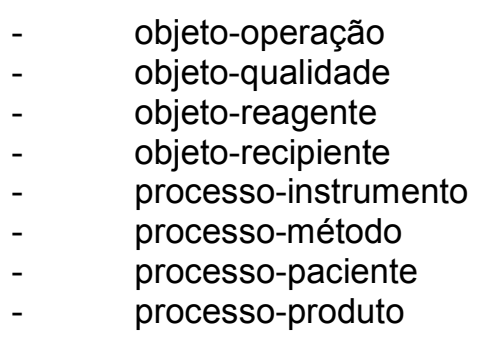

Teorias prototípicas, baseadas em estudos de categorização, também estão sendo utilizadas atualmente para a estruturação do léxico, porém, afastam-se de alguns princípios lingüísticos inerentes ao trabalho terminológico.

Assim, ainda que existam variações teóricas, as categorias ditas "clássicas", entendendo-se aqui as relações hierárquicas e não-hierárquicas, são ainda bastante úteis e utilizadas na estruturação de terminologias.

No presente trabalho, o enfoque recairá sobre as relações hierárquicas. Isso porque as relações de hiperonímia, hiponímia e co-hiponímia são de extrema importância no desenvolvimento de um trabalho terminológico (suas conseqüências serão tratadas posteriormente) e, até o presente momento, são as mais produtivas para nossa análise.

\subsubsection{Relações hierárquicas}

As relações hierárquicas são definidas pela Norma ISO 704 da seguinte maneira:

In a hierarchical relation, concepts are organized into levels where the superordinate concept is subdivided into at least one subordinate concept. Subordinate concepts at the same level and having the same criterion of subdivision are called coordinate concepts (...). Concepts are superordinate, subordinate or coordinate, not on their own, but in relation to each other in a hierarchy.

Assim, a divisão de um conceito pode conduzir à formação em séries verticais e 
horizontais de conceitos.

Existem ainda dois tipos fundamentais de relações hierárquicas: as relações genéricas e as relações partitivas.

A Norma ISO 1087 define as relações partitivas como "a relation between two concepts where one of the concepts constitutes the whole and the other concept a part of the whole" (ISO 1087, 2000). As noções podem ser consideradas integrantes ou partitivas, sendo que as integrantes correspondem ao conceito superordenado e as partitivas ao conceito subordinado. Como exemplo pode-se citar:

\section{1. alinhamento}

\section{1. alinhamento múltiplo}

\subsection{2. alinhamento múltiplo de seqüência}

em que alinhamento é noção integrante e alinhamento múltiplo e alinhamento múltiplo de seqüência são noções partitivas.

Por relações genéricas entende-se "a relation between two concepts where the intension of the concept includes that of the other concept and at least one additional delimiting characteristic" (ISO 1087, 2000). Assim, uma noção específica é um conceito subordinado a um conceito genérico, sendo que ta noção possui ao menos uma característica a mais que o seu genérico. Já a noção genérica inclui as noções específicas e estabelece relações de hierarquia com as mesmas. Como exemplo:

\section{Genética Molecular}

\subsection{Fundamentos}

1.2. Tecnologia

\subsection{Aplicações}

\subsection{Estrutura}

\subsubsection{DNA}

\subsubsection{DNA recombinante}

\subsubsection{DNA repetitivo}

\subsection{DNA repetitivo não-funcional}




\subsubsection{DNA satélite}

\subsubsection{DNA transformante}

\subsubsection{DNA unifilamentar}

\subsubsection{DNA vetor}

em que a genética molecular é noção genérica em relação a fundamentos, tecnologia, aplicações e estrutura, que por sua vez, são noções genéricas em relação a DNA e esta em relação a DNA recombinante e DNA repetitivo, etc...As noções específicas são dadas em sentido contrário: DNA repetitivo e DNA recombinante são específicas a DNA e assim por diante.

De modo geral, em uma relação hierárquica, a noção genérica mantém com a noção específica uma relação de inclusão, que se denomina relação hiperonímica-hiponímica. Os hipônimos, porém, quando mantêm uma relação de equivalência, ou seja, estão em um mesmo nível de abstração em um sistema estruturado, estão em situação de co-hiponímia. No exemplo citado, os termos DNA repetitivo e DNA recombinante estão em um mesmo nível; são, portanto, co-hipônimos.

Assim, os co-hipônimos, em sua definição, terão a mesma descrição genérica de DNA, porém têm suas especificidades acrescidas; portanto, são os semas distintivos que dão a noção de especificidade.

Uma outra questão, semântica, se coloca quando da estruturação do vocabulário. Trata-se da extensão e compreensão dos conceitos. Nos tipos de relações exemplificados acima, os conceitos superordenados apresentam superioridade em sua extensão semântica e, por sua vez, inferioridade em sua compreensão. O inverso ocorre com os conceitos subordinados: têm sua compreensão mais abrangente do que sua extensão.

John Lyons (1970, p.133) explica os conceitos de extensão e compreensão da seguinte forma:

A extensão de um termo concerne a uma classe de entidades às quais se aplica ou refere um termo, sua compreensão é o conjunto de atributos que caracterizam toda entidade à qual o termo pode ser aplicado. A extensão e a compreensão são inversamente proporcionais uma à outra, no sentido de que quanto maior a extensão de um termo, mais sua compreensão é restrita, e vice-versa .

A título de exemplificação: a compreensão de DNA poderia ser descrita como a sua 
definição, propriamente dita. Já sua extensão poderia ser descrita como os diversos tipos de DNA existentes, uma enumeração: DNA satélite, DNA transformante, etc.

\subsubsection{Importância da elaboração de estruturas conceptuais para um trabalho terminográfico}

Ainda que não-usual entre os pesquisadores, a elaboração de uma estrutura que explicite as relações conceptuais entre os termos de determinado campo de conhecimento se faz bastante relevante.

Barros (2004, p.118-128) levanta alguns pontos de um trabalho terminográfico em que a elaboração dessa estrutura se faz importante: "na escolha da nomenclatura, no tratamento dos dados, na organização do sistema de remissivas, no aprofundamento de uma dada pesquisa terminológica”.

\subsubsection{1. da escolha da nomenclatura}

Homogeneidade é um fator bastante relevante em uma obra terminográfica. $\mathrm{O}$ conhecimento da área-objeto, assim como de suas subáreas, garante um equilíbrio maior à obra. Este fato ocorre porque é possível, por meio da estruturação do vocabulário, delimitar a quantidade de termos de cada campo e dos subdomínios correlatos à área em questão, não privilegiando ou causando prejuízo aos consulentes.

\subsubsection{2. do tratamento dos dados terminográficos}

Neste ponto, a configuração da macroestrutura, da microestrutura e do sistema de remissivas em uma obra revela-se como conseqüência direta da estruturação semântica do vocabulário.

Para a determinação da nomenclatura de um dicionário terminológico, um conjunto estruturado dos termos que explicite as relações semânticas que se estabelecem entre eles é de fundamental importância, já que ele pode delimitar com maior precisão a zona de intersecção entre conjuntos de termos e definir os traços característicos de cada um desses termos. 
No entanto, a grande contribuição da estrutura conceptual está relacionada às definições terminológicas. De acordo com Sager (1993, p.45):

Es necesario situar el concepto dentro de su estructura de conocimiento que lo delimita y lo confirma, darle una denominación para poder referirnos claramente a él y definirlo como acto de clarificación, confirmación o fijación de un elemento del conocimiento.

Segundo o Autor, a definição terminológica consiste em um processo e em um produto: "el proceso de explicar el significado expresado lingüísticamente" e "como producto, es la descripción lingüística de un concepto, basada en un listado de un número de características del significado del concepto".

Partindo do princípio de que em uma definição terminológica o termo só pode ser entendido enquanto unidade constituinte do sistema conceitual do qual faz parte, é possível, então, estabelecer tipologias definicionais para os diferentes campos nocionais constituintes de uma área de conhecimento.

$\mathrm{O}$ estabelecimento de tipologias definicionais garante homogeneidade à obra. Assim, todo termo pertencente a um mesmo campo conceptual receberá igual tratamento em sua definição, o que assegura que as informações relevantes não escapem ao terminólogo quando da elaboração de seu dicionário.

Um outro fator bastante importante, que também se resolve com a implementação desses padrões, está relacionado ao trabalho em equipe. Esses padrões acabam se tornando um instrumento de consolidação.

Nas palavras de Barros (2004, p.123):

[...] a homogeneidade na recolha e no tratamento dos dados [...] foi possível graças à delimitação do domínio, à organização dos termos em um sistema conceptual e à precisa determinação dos recortes conceptuais dados ao termo definido, recortes que determinaram o conjunto de dados terminológicos e sua distribuição em campos dentro da microestrutura.

Outros benefícios da elaboração desses sistemas de conceitos são: a organização de um sistema de remissivas mais confiável e que realmente leve o consulente a recuperar dados pesquisados em um dicionário, e a possibilidade de aprofundamento da pesquisa terminológica, uma vez que, em posse de uma lista previamente elaborada, torna-se possível a expansão do conjunto de entradas para constar do dicionário. Portanto, um dicionário terminológico que conte com uma metodologia que preveja a organização do 
conjunto terminológico em um sistema de conceitos tem maiores garantias de homogeneidade e de uniformidade, feito que se espera em um trabalho desse tipo.

\section{Análises}

\subsection{Descrição das formações da terminologia da Genética Molecular}

$\mathrm{Na}$ descrição da formação da terminologia da Genética Molecular, algumas unidades terminológicas merecem destaque como, por exemplo, os sintagmas formados por 
elementos estrangeiros ou siglas - primer sintético (s.m.) - S(estrang.) + Adj. e RNA antisense (s.m.) - S(sigla) + Adj.(estrang.), além das unidades cujo formante (prefixo ou sufixo) importa mencionar: clivagem (s.f.) - clivar + -agem.

Para tanto, utilizamos subtítulos com a fórmula de composição das unidades terminológicas ( $\mathrm{S}+\mathrm{SAdj}$, composição: base presa / base livre, por exemplo) na descrição de sua morfologia, o que acaba por tornar tal marcação bastante repetitiva. Porém, pelo fato de uma grande parte dos termos dever receber descrição mais detalhada, tal procedimento foi tomado como padrão.

Cabe ressaltar que alguns termos, devido a sua ampla divulgação, já se encontram atestados por obras de referência, como os dicionários Aurélio e Houaiss. Assim, pudemos analisar os processos de formação de palavras de nosso corpus de pesquisa baseando-nos também em tais materiais de consulta.

Segue, então, a descrição dos processos de formação da terminologia da Genética Molecular.

\subsubsection{Derivação}

\subsubsection{Derivação prefixal}

anticorpo (s.m.) - anti- + corpo

autoduplicação (s.f.) - auto- + duplicação

auto-radiograma (s.m.) - auto- + radiograma

auto-replicação (s.f.) - auto- + replicação

autossomo (s.m.) - aut(o)- + -somo

biobalística (s.f.) - bio- + balística

bioenergética (s.f.) - bio- + energética

bioética (s.f.) - bio- + ética

bioinformática (s.f.) - bio- + informática

biomolécula (s.f.) - bio- + molécula

biotecnologia (s.f.) - bio- + tecnologia

centimorgan (s.m.) - centi- + Morgan

co-fator (s.m.) - co- + fator

dimorfismo (s.m.) - di- + morfismo

macromolécula (s.f.) - macro- + molécula

megabase (s.f.) - mega- + base

minisseqüência (s.f.) - mini- + seqüência

minisseqüenciamento (s.f.) - mini- + seqüenciamento

pluripotência/multipotência (s.f.) - pluri-/multi- + potência

pronúcleo (s.m.) - pro- + núcleo

pró-vírus (s.m.) - pró- + vírus

recombinação (s.f.) - re- + combinação

resseqüênciamento (s.m.) - re- + seqüênciamento

retrotransposon (s.m.) - retro- + transposon

retrovírus (s.m.) - retro- + vírus 
subclonagem (s.f.) - sub- + clonagem

transdiferenciação (s.f.) - trans- + diferenciação

transgene (s.m.) - trans- + gene

transgênese (s.f.) - trans- + gênese

ultracentrifugação (s.f.) - ultra- + centrifugação

unipotente (adj.) - uni- + potente

\subsubsection{Derivação sufixal}

acetilação (s.f.) - acetilar + -ção

alinhamento (s.m.) - alinhar + -mento

amplificação (s.f.) - amplificar + -ção

anotação (s.f.) - anotar + -ção

bandeamento (s.m.) - bandear + -mento

carreador (s.m.) - carrear + -dor

casamento (s.m.) - casar + -mento

centrifugação (s.f.) - centrifugar + -ção

circularização (s.f.) - circularizar + -ção

clarificação (s.f.) - clarificar + -ção

clivagem (s.f.) - clivar + -agem

clonagem (s.f.) - clonar + -agem

conjugação (s.f.) - conjugar + -ção

conservação (s.f.) - conservar + -ção

cosmídeo (s.m.) - cosm(o)- + -ídeo

deleção (s.f.) - deletar + -ção

diferenciação (s.f.) - diferenciar + -ção

dimerização (s.f.) - dimerizar + -ção

disposição (s.f.) - dispor + -ção

encadeamento (s.m.) - encadear + -mento

fecundação (s.f.) - fecundar + -ção

fluorescência (s.f.) - fluorescer + -ência

genoma (s.m.) - gene + -oma

genômica (s.f.) - genoma + -ico

genotipagem (s.f.) - genótipo + -agem

glicosilação (s.f.) - glicosilar + -ção

helicoidização (s.f.) - helicoidizar + -ção

hibridização (s.f.) - hibridizar + -ção

hospedeiro (s.m.) - hóspede + -eiro

inoculação (s.f.) - inocular + -ção

inserção (s.f.) - inserir + -ção

interação (s.f.) - interagir + -ção

ligação (s.f.) - ligar + -ção

ligase (s.f.) - ligar + -ase

linhagem (s.f.) - linha + -agem

mapeamento (s.m.) - mapear + -mento

marcador (s.m.) - marcar + -dor

meiose (s.f.) - meio- + -ose

metilação (s.f.) - metilar + -ção

mitose (s.f.) - mito- + -ose

modelagem (s.f.) - modelar + -agem

mutação (s.f.) - mutar + -ção

nuclease (s.f.) - núcleo + -ase

nucleotídeo (s.m.) - nucle(i/o)- + -t- + -ídeo

ordenamento (s.m.) - ordenar +- -mento

plaqueamento (s.f.) - plaquear + -mento 
plasmídeo (s.m.) - plasma (plasm(at)-) + -ídeo

polimerização (s.f.) - polimerizar + -ção

proteoma (s.f.) - prote(i/o)- + -oma

proteômica (s.f.) - proteoma + -ico

quimioterápico (adj.) - quimioterapia + -ico

radioatividade (s.f.) -radioativo + -(i)dade

regulação (s.f.) - regular + -ção

remoção (s.f.) - remover + -ção

replicação (s.f.) - replicar + -ção

segregação (s.f.) - segregar + -ção

seqüenciamento (s.m.) - seqüenciar + -mento

similaridade (s.f.) - similar + -(i)dade

simulação (s.f.) - simular + -ção

substituição (s.f.) - substituir + -ção

tradução (s.f.) - traduzir + -ção

tranferência (s.f.) - transferir + -ência

transcrição (s.f.) - transcrever + -ção

transfecção (s.f.) - tranferir + -ção

transformação (s.f.) - transformar + -ção

transgenia (s.f.) - transgene + -ia

transgênico (adj.) - transgene + -ico

translação (s.f.) - transladar + -ção

triagem (s.f.) - triar + -agem

promotor (s.m.) - promover + -or

transcriptoma (s.f.) - transcrição + -oma

transcritase (s.f.) - transcrição + -ase

\subsubsection{Formação sintagmática}

\subsubsection{1. $S+$ Adj.}

abordagem dirigida (s.f.) $-\mathrm{S}+$ Adj .

aconselhamento genético (s.m.) - S + Adj.

aconselhamento não-coercitivo (s.m.) - S + Adj.

aconselhamento não-diretivo (s.f.) - $\mathrm{S}+\mathrm{Adj}$.

agente imunomodulador (s.m.) - $\mathrm{S}+$ Adj.

agrupamento hierárquico (s.m.) - $\mathrm{S}+$ Adj.

alelo múltiplo (s.m.) - S + Adj.

alelo nulo (s.m.) - S + Adj.

alelo selvagem (s.m.) $-\mathrm{S}+\mathrm{Adj}$.

algoritmo destruidor (s.m.) - S + Adj.

algoritmo heurístico (s.m.) - S + Adj.

alinhamento global (s.m.) - S + Adj.

alinhamento local (s.m.) - S + Adj.

alinhamento múltiplo (s.m.) - $\mathrm{S}+$.Adj

alinhamento progressivo (s.m.) - $\mathrm{S}+\mathrm{Adj}$.

análise citogenética (s.f.) - $\mathrm{S}+\mathrm{Adj}$.

analise filogenética (s.f.) - $\mathrm{S}+\mathrm{Adj}$.

análise mutacional (s.f.) - $\mathrm{S}+$ Adj.

anotação manual (s.f.) - $S+$ Adj.

anticorpo anti-DNA (s.m.) - S + Adj.

árvore filogenética (s.f.) $-\mathrm{S}+\mathrm{Adj}$.

banda plasmidial (s.f.) $-\mathrm{S}+$ Adj. 
biblioteca genômica (s.f.) - S + Adj.

biologia computacional (s.f.) $-\mathrm{S}+$ Adj. candidato funcional (s.m.) - S + Adj.

candidato posicional (s.m.) - S + Adj.

caracterização genômica (s.f.) - S + Adj.

célula cumulus (s.f.) - $\mathrm{S}+\mathrm{Adj}$.

célula alogenética (s.f.) $-\mathrm{S}+$ Adj.

célula apresentadora (s.f.) $-\mathrm{S}+$ Adj.

célula autóloga (s.f.) - $\mathrm{S}+\mathrm{Adj}$.

célula circulante (s.f.) $-\mathrm{S}+\mathrm{Adj}$.

célula embrionária (s.f.) $-\mathrm{S}+$ Adj.

célula funcional (s.f.) $-\mathrm{S}+\mathrm{Adj}$.

célula germinativa $-\mathrm{CG}$ (s.f.) $-\mathrm{S}+$ Adj.

célula heterotópica (s.f.) $-\mathrm{S}+\mathrm{Adj}$.

célula homotópica (s.f.) $-\mathrm{S}+$ Adj.

célula imunocompetente (s.f.) $-\mathrm{S}+\mathrm{Adj}$.

célula multipotente (s.f.) - $\mathrm{S}+\mathrm{Adj}$.

célula receptora (s.f.) - $\mathrm{S}+$ Adj.

célula somática (s.f.) - $\mathrm{S}+\mathrm{Adj}$.

clonagem genômica (s.f.) - $\mathrm{S}+$ Adj .

clonagem humana (s.f.) $-\mathrm{S}+\mathrm{Adj}$.

clonagem posicional (s.f.) $-\mathrm{S}+$ Adj.

clonagem reprodutiva (s.f.) $-\mathrm{S}+$ Adj.

clonagem terapêutica (s.f.) - $\mathrm{S}+$ Adj.

clone auto-reativo (s.m.) - S + Adj.

clone natural (s.m.) - S + Adj.

clone positivo (s.m.) - S + Adj.

clone superposto (s.m.) - S + Adj.

código genético (s.m.) - S + Adj.

códon finalizador (s.m.) - S(estrang.) + Adj.

códon traducional (s.m.) - S(estrang.) + Adj..

compatibilidade genética (s.f.) - $\mathrm{S}+$ Adj.

complementação funcional (s.f.) $-\mathrm{S}+\mathrm{Adj}$.

computação paralela (s.f.) - S + Adj.

cromossomo artificial (s.m.) - S + Adj.

cromossomo homólogo (s.m.) - S + Adj.

cromossomo politênico (s.m.) - S + Adj.

cromossomo sexual (s.m.) - S + Adj.

filtração tangencial (s.f.) - $\mathrm{S}+$ Adj.

disrupção sônica (s.f.) - S + Adj.

dissecção genética (s.f.) $-\mathrm{S}+$ Adj.

diversidade genética (s.f.) $-\mathrm{S}+$ Adj.

duplicação cromossômica (s.f.) - S + Adj.

embrião humano (s.m.) - S + Adj.

engenharia genética (s.f.) - $\mathrm{S}+$ Adj.

esqueleto molecular (s.m.) - $\mathrm{S}+$ Adj.

estrutura primária (s.f.) - $\mathrm{S}+$ Adj.

evolução gênica (s.f.) - $\mathrm{S}+$ Adj.

expressão gênica (s.f.) - $S+$ Adj.

filtro politênico (s.m.) - S + Adj.

fita-senso (s.f.) - $\mathrm{S}+$ Adj.

fusão celular (s.f.) $-\mathrm{S}+\mathrm{Adj}$.

gel bidimensional (s.m.) - S + Adj.

gel desnaturante (s.m.) - S + Adj.

gene desligado (s.m.) - $\mathrm{S}+$ Adj.

gene ligado (s.m.) - S + Adj. 
gene associado (s.m.) - S + Adj.

gene ativador (s.m.) - S Adj.

gene ativo (s.m.) $-\mathrm{S}+$ Adj.

gene-candidato (s.m.) - S + Adj.

gene co-regulador (s.m.) - S + Adj.

gene clonado (s.m.) - S + Adj.

gene deletério (s.m.) - S + Adj.

gene essencial (s.m.) - S Adj.

gene estrutural (s.m.) - S + Adj.

gene exógeno (s.m.) - $\mathrm{S}+\mathrm{Adj}$.

gene heterólogo (s.m.) - S + Adj.

gene não-essencial (s.m.) - S + Adj.

gene ortólogo (s.m.) - S + Adj.

gene perturbado (s.m.) - S + Adj.

gene programado (s.m.) - S + Adj.

gene regulador (s.m.) - $\mathrm{S}+$ Adj.

gene repórter (s.m.) - $\mathrm{S}+\mathrm{Adj}$.

gene repressor (s.m.) - S + Adj.

gene saltador (s.m.) - S + Adj.

gene suicida (s.m.) - S + Adj.

gene viral (s.m.) - S + Adj.

genética bacteriana (s.f.) $-\mathrm{S}+\mathrm{Adj}$.

genética bioquímica (s.f.) - $\mathrm{S}+\mathrm{Adj}$.

genética forense (s.f.) - S + Adj.

genética molecular (s.f.) - S + Adj.

genética reversa (s.f.) $-\mathrm{S}+\mathrm{Adj}$.

genoma doador (s.m.) - S + Adj.

genoma eucariótico (s.m.) - S + Adj.

genoma mitocondrial (s.m.) - S + Adj.

genoma nuclear (s.m.) - S + Adj.

genoma viral (s.m.) - S + Adj.

genômica comparativa (s.f.) - S + Adj.

genômica estrutural (s.f.) - S + Adj.

genômica funcional (s.f.) - $\mathrm{S}+\mathrm{Adj}$.

herança monogênica (s.f.) - S + Adj.

heterocárion binucleado (s.m.) - S + Adj.

hibridização unifilamentar (s.f.) - S + Adj.

híbrido celular (s.m.) - S + Adj.

homologia estrutural (s.f.) - S + Adj.

infecção viral (s.f.) - S + Adj.

inserção ectópica (s.f.) - S + Adj.

instabilidade cromossômica (s.f.) - S + Adj.

interação interatômica (s.f.) - S + Adj.

interação intermolecular (s.f.) - $\mathrm{S}+$ Adj.

interferência filogenética (s.f.) - S + Adj.

isolamento gênico (s.m.) - S + Adj.

junção comunicante (s.f.) - $\mathrm{S}+\mathrm{Adj}$.

linhagem celular (s.f.) - $\mathrm{S}+$ Adj.

linhagem específica (s.f.) - S + Adj.

linhagem mutante (s.f.) $-\mathrm{S}+$ Adj.

loci heterocigoto (s.m.) - S + Adj.

mapa físico (s.f.) $-\mathrm{S}+\mathrm{Adj}$.

mapa genético (s.f.) $-\mathrm{S}+\mathrm{Adj}$.

mapa genômico (s.f.) $-\mathrm{S}+\mathrm{Adj}$.

mapa auto-organizável (s.f.) - $\mathrm{S}+\mathrm{Adj}$.

mapeamento cromossômico (s.m.) - S + Adj. 
marcador biparental (s.m.) - S + Adj. marcador diagnóstico (s.m.) - $\mathrm{S}+$ Adj. marcador farmacodinâmico (s.m.) - S + Adj. marcador haplotípico (s.m.) - S + Adj. marcador humano (s.m.) - S + Adj. marcador molecular (s.m.) - S + Adj. marcador morfológico (s.m.) - $\mathrm{S}+$ Adj. marcador neutro (s.m.) - $\mathrm{S}+\mathrm{Adj}$. marcador uniparental (s.m.) - S + Adj. método estatístico (s.m.) - S + Adj. microscopia eletrônica (s.f.) $-\mathrm{S}+\mathrm{Adj}$. modelagem bioquímica (s.f.) $-\mathrm{S}+$ Adj. modelagem fisiológica (s.f.) $-\mathrm{S}+\mathrm{Adj}$. modelagem molecular (s.f.) $-\mathrm{S}+$ Adj. modelo intrínseco (s.m.) - S + Adj. modelo probabilístico (s.m.) $-\mathrm{S}+$ Adj. molécula quimérica (s.f.) - $\mathrm{S}+$ Adj. molécula recombinante (s.f.) $-\mathrm{S}+$ Adj. molécula replicante (s.f.) $-\mathrm{S}+$ Adj. motivo conservado (s.m.) - $\mathrm{S}+$ Adj. multiplicação celular (s.f.) $-\mathrm{S}+\mathrm{Adj}$. mutação auxotrófica (s.f.) - $\mathrm{S}+$ Adj. mutação conservativa (s.f.) $-\mathrm{S}+\mathrm{Adj}$. mutação deletéria (s.f.) - $\mathrm{S}+\mathrm{Adj}$. mutação dinâmica (s.f.) - $\mathrm{S}+\mathrm{Adj}$. mutação direcionada (s.f.) $-\mathrm{S}+$ Adj. mutação espontânea (s.f.) - S + Adj. mutação induzida (s.f.) - $\mathrm{S}+\mathrm{Adj}$. mutação marcadora (s.f.) - S + Adj. mutação nula (s.f.) - $\mathrm{S}+$ Adj. mutação patogênica (s.f.) - $\mathrm{S}+$ Adj. mutação polimórfica (s.f.) $-\mathrm{S}+\mathrm{Adj}$. mutação pontual (s.f.) $-\mathrm{S}+\mathrm{Adj}$. mutação segmentar (s.f.) - $\mathrm{S}+$ Adj. mutação sinônima (s.f.) - S + Adj. mutante nulo (s.m.) - S + Adj. necessidade auxotrófica (s.f.) $-\mathrm{S}+\mathrm{Adj}$. nucleotídeo alternativo (s.m.) - S + Adj. oligonucleotideo sintético (s.m.) - S + Adj. óperon ribosomal (s.m.) - S(estrang.) + Adj. organismo doador (s.m.) - S + Adj. organismo não-patogênico (s.m.) - $\mathrm{S}+$ Adj. organismo projetado (s.m.) - S + Adj. organismo transgênico (s.m.) - $\mathrm{S}+$ Adj. organizador nucleolar (s.m.) $-\mathrm{S}+\mathrm{Adj}$. orientação antiparalela (s.f.) - S + Adj. padrão flexível (s.m.) - S + Adj. patrimônio genético (s.m.) - $\mathrm{S}+\mathrm{Adj}$. perfil farmacocinético (s.m.) - S + Adj. perfil farmacodinâmico (s.m.) - $\mathrm{S}+$ Adj. perfil genético (s.m.) - $\mathrm{S}+$ Adj.

perturbação gênica (s.f.) - (S + Adj. pistola gênica (s.f.) - $\mathrm{S}+\mathrm{Adj}$. plasmídeo bacteriano (s.m.) - S + Adj. ponta adesiva (s.f.) $-\mathrm{S}+\mathrm{Adj}$. ponta coesiva (s.f.) - $S+$ Adj. 
ponto isoelétrico (s.m.) - S + Adj.

primer sintético (s.m.) - S(estrang.) + Adj.

produto protéico (s.m.) - $\mathrm{S}+$ Adj.

programação dinâmica (s.m.) - S + Adj.

promotor tardio (s.m.) - S + Adj.

proporção fenotípica (s.f.) - S + Adj.

proteína análoga (s.f.) - S + Adj.

proteína estrutural (s.f.) $-\mathrm{S}+$ Adj.

proteína heteróloga (s.f.) - S + Adj.

proteína homóloga (s.f.) - S + Adj.

receptor nuclear (s.m.) - S + Adj.

recombinação homóloga (s.f.) - S + Adj.

recombinação meiótica (s.f.) $-\mathrm{S}+$ Adj.

rede gênica (s.f.) $-\mathrm{S}+$ Adj.

região acentuadora (s.f.) - $\mathrm{S}+$ Adj.

região controladora (s.f.) $-\mathrm{S}+$ Adj.

região promotora (s.f.) $-\mathrm{S}+\mathrm{Adj}$.

região reguladora (s.f.) $-\mathrm{S}+\mathrm{Adj}$.

região regulatória (s.f.) $-\mathrm{S}+\mathrm{Adj}$.

regulação desenvolvimental (s.f.) - S + Adj.

regulação gênica (s.f.) - $\mathrm{S}+$ Adj.

repetição centromérica (s.f.) $-\mathrm{S}+\mathrm{Adj}$.

replicação autônoma (s.f.) - $\mathrm{S}+\mathrm{Adj}$.

replicação prolífica (s.f.) - $\mathrm{S}+$ Adj.

replicação semiconservativa (s.f.) - S + Adj.

reprodução assistida (s.f.) - S + Adj.

scanner confocal (s.m.) - S(estrang.) + Adj.

segmento genético (s.m.) - S + Adj.

seqüência funcional (s.f.) $-\mathrm{S}+\mathrm{Adj}$.

seqüência parcial (s.f.) - $S+\operatorname{Adj}$.

seqüência reguladora (s.f.) - $\mathrm{S}+$ Adj.

seqüência repetitiva (s.f.) $-\mathrm{S}+\mathrm{Adj}$.

seqüência terminadora (s.f.) $-\mathrm{S}+$ Adj.

seqüenciador automático (s.m.) - S + Adj.

significância estatística (s.f.) - $\mathrm{S}+$ Adj.

simulação bioquímica (s.f.) $-\mathrm{S}+$ Adj.

simulação molecular (s.f.) - $\mathrm{S}+$ Adj.

sítio doador (s.m.) - S + Adj.

tecnologia verde (s.f.) $-\mathrm{S}+\mathrm{Adj}$.

terapia celular (s.f.) $-\mathrm{S}+$ Adj.

terapia gênica (s.f.) - $S+$ Adj.

terapia germinativa (s.f.) $-\mathrm{S}+$ Adj.

terapia heterotópica (s.f.) $-\mathrm{S}+$ Adj.

terapia homotópica (s.f.) - S + Adj.

tipagem sanguínea (s.f.) $-\mathrm{S}+$ Adj.

tradução reversa (s.f.) $-\mathrm{S}+$ Adj.

transcritase reversa (s.f.) - $\mathrm{S}+$ Adj.

transdução viral (s.f.) - $\mathrm{S}+$ Adj.

transfecção retroviral (s.f.) - $\mathrm{S}+$ Adj.

transferência gênica (s.f.) - $\mathrm{S}+\mathrm{Adj}$.

transferência nuclear (s.f.) $-\mathrm{S}+$ Adj.

transitor molecular (s.m.) - S + Adj.

transplante alogenéico (s.m.) - S + Adj.

transplante autólogo (s.m.) - S + Adj.

transposon endógeno (s.m.) - S(estrang.) + Adj.

triagem genética (s.f.) - $\mathrm{S}+$ Adj. 
variante genética (s.f.) - $\mathrm{S}+$ Adj.

vetor adenoviral (s.m.) $-\mathrm{S}+$ Adj.

vetor genético (s.m.) - $\mathrm{S}+\mathrm{Adj}$.

vetor lentiviral (s.m.) $-\mathrm{S}+\mathrm{Adj}$.

vetor não-viral (s.m.) - S + Adj.

vetor plasmidial (s.m.) - $\mathrm{S}+$ Adj.

vetor recombinante (s.m.) - S + Adj.

vetor retroviral (s.m.) $-\mathrm{S}+\mathrm{Adj}$.

vetor viral (s.m.) - $\mathrm{S}+\mathrm{Adj}$.

via metabólica (s.f.) - $\mathrm{S}+\mathrm{Adj}$.

via regulatória (s.f.) $-\mathrm{S}+\mathrm{Adj}$.

vírus adenoassociado (s.m.) - $\mathrm{S}+$ Adj.

\subsubsection{2. $S+$ SAdj.}

abordagem hit-throughput (s.f.) - S + SAdj.(estrang.)

abordagem shotgun (s.f.) - S + SAdj.(estrang.)

algoritmo ramo-e-limite (s.m.) - S + SAdj.(comp.)

alinhamento par-a-par (s.m.) - S + SAdj.(comp.)

alinhamento perfil-perfil (s.m.) - S + SAdj. (comp.)

alinhamento perfil-seqüência (s.m.) - S + SAdj.

câmera CCD (s.f.) - S + SAdj.(sigla)

célula EG (s.f.) - S + SAdj.(sigla)

célula ES (s.f.) - $\mathrm{S}+\mathrm{SAdj}$. (sigla)

clonagem shotgun (s.f.) - S + SAdj.(estrang.)

códon nonsense (s.m.) - S(estrang.) + SAdj. (estrang.)

distância Jukes-Cantor (s.f.) - S + SAdj. (epônimo)

disposição cis (s.f.) - S + SAdj.(estrang.)

fita anti-senso (s.f.) - $\mathrm{S}+\mathrm{SAdj}$.

formato FASTA (s.m.) - S + SAdj.(sigla)

linguagem FORTRAN (s.f.) - S + SAdj.(sigla)

marcador microssatélite (s.m.) - S + SAdj.

marcador minissatélite (s.m.) - S + SAdj.

mutação frame-shift (s.f.) - S + SAdj. (estrang.)

mutagênese sítio-dirigida (s.f.) $-\mathrm{S}+\mathrm{SAdj}$.

mutagênese sítio-dirigida (s.f.) $-\mathrm{S}+\mathrm{SAdj}$.

seqüência EST (s.f.) - S + SAdj.(sigla)

seqüenciamento didesóxi (s.m.) - S + SAdj.

valor E (s.m.) - S + SAdj.(sigla)

\subsubsection{S(composto $)+A d j$.}

célula-tronco adulta (s.f.) - S(composto) + Adj.

célula-tronco autóloga (s.f.) - S(composto) + Adj.

célula-tronco circulante (s.f.) - S(composto) + Adj.

célula-tronco embrionária (s.f.) - $\mathrm{S}$ (composto) + Adj.

célula-tronco exógena (s.f.) - S(composto) + Adj.

célula-tronco germinativa (s.f.) - S(composto) + Adj.

célula-tronco hematopoiética (s.f.) - $\mathrm{S}$ (composto) + Adj.

célula-tronco hepática (s.f.) - $\mathrm{S}$ (composto) + Adj.

célula-tronco mesenquimal (s.f.) - $\mathrm{S}$ (composto) + Adj.

celula-tronco neuronal (s.f.) - S(composto) + Adj.

célula-tronco pluripotente (s.f.) - $\mathrm{S}$ (composto) + Adj.

célula-tronco tecidual (s.f.) - S(composto) + Adj. 
célula-tronco totipotente (s.f.) - $\mathrm{S}$ (composto) + Adj.

fago-vetor unifilamentar (s.m.) - S(composto) + Adj.

\subsubsection{S(composto $)+$ Adj. + Adj.}

célula-tronco embrionária diferenciada (s.f.) - S(composto) + Adj. + Adj. célula-tronco embrionária humana (s.f.) - S(composto) + Adj. + Adj. célula-tronco embrionária indiferenciada (s.f.) - S(composto) + Adj. + Adj. célula-tronco embrionária pluripotente (s.f.) - S(composto) + Adj. + Adj. célula-tronco embrionária recombinante (s.f.) - S(composto) + Adj. + Adj. célula-tronco hematopoiética embrionária (s.f.) - S (composto) + Adj. + Adj. célula-tronco neural adulta (s.f.) - S(composto) + Adj. + Adj.

\subsubsection{5. $S+$ Adj. + Adj.}

aconselhamento genético prospectivo (s.f.) - S + Adj. + Adj. aconselhamento genético retrospectivo (s.f.) $-\mathrm{S}+\mathrm{Adj}$. Adj. célula germinal humana (s.f.) $-\mathrm{S}+\mathrm{Adj}$. + Adj. célula multipotente alogênica (s.f.) - S + Adj. + Adj. célula multipotente autóloga (s.f.) - S + Adj. + Adj. célula progenitora adulta multipotente (s.f.) $-\mathrm{S}+$ Adj. + Adj. + Adj. célula somática diferenciada (s.f.) - S + Adj. + Adj. clonagem reprodutiva humana (s.f.) $-\mathrm{S}+\mathrm{Adj} .+$ Adj. cromossomo artificial humano (s.m.) - S + Adj. + Adj. elemento genético móvel (s.m.) - S + Adj. + Adj. elemento intercalare curto (s.m.) - S + Adj. + Adj. elemento intercalare longo (s.m.) - S + Adj. + Adj. gene clonado mutado (s.m.) - S + Adj. + Adj.

gene clonado selvagem (s.m.) - S + Adj. + Adj. gene funcional único (s.m.) - S + Adj. + Adj. indutor químico externo (s.m.) - S + Adj. + Adj. linhagem mutante auxotrófica (s.f.) $-\mathrm{S}+$ Adj. + Adj. locus marcador heterozigoto (s.m.) - S + Adj. + Adj. marcador toxicológico potencial (s.m.) - S + Adj + Adj. patrimônio genético natural (s.m.) - S + Adj. + Adj. ponta adesiva complementar (s.f.) - S + Adj. + Adj. ponta adesiva unifilamentar (s.f.) - S + Adj. + Adj. proporção fenotípica padrão (s.f.) - S + Adj. + Adj. proteína homóloga homeótica (s.f.) - $\mathrm{S}+$ Adj. + Adj. recurso microbiano abrangente (s.m.) $-\mathrm{S}+\mathrm{Adj}+\mathrm{Adj}$. ressonância nuclear magnética (s.f.) - $\mathrm{S}+$ Adj. + Adj. seqüência funcional codificante (s.f.) - $\mathrm{S}+$ Adj. + Adj. seqüência funcional não-codificante (s.f.) - S + Adj. + Adj. seqüência reguladora anterior (s.f.) - $\mathrm{S}+$ Adj. + Adj. seqüência reguladora posterior (s.f.) $-\mathrm{S}+$ Adj. + Adj. seqüência repetitiva funcional (s.f.) - $\mathrm{S}+$ Adj. + Adj. seqüência repetitiva não-funcional (s.f.) - $\mathrm{S}+\mathrm{Adj}$. + Adj. seqüenciamento protéico automatizado (s.m.) - S + Adj. + Adj. sistema capilar microscópico (s.m.) - S + Adj. + Adj. sítio mutagênico ativo (s.m.) - S + Adj. + Adj. sonda oligonucleotídica sintética (s.f.) - S + Adj. + Adj. técnica analítica quantitativa (s.f.) - S + Adj. +Adj. terapia celular heterotópica (s.f.) - $\mathrm{S}+\mathrm{Adj}$. + Adj. terapia gênica somática (s.f.) $-\mathrm{S}+\mathrm{Adj}$. + Adj. 
terapia gênica viral (s.f.) - S + Adj. + Adj.

terminação repetitiva longa (s.f.) $-\mathrm{S}+$ Adj. + Adj.

transcritase reversa viral (s.f.) $-\mathrm{S}+$ Adj. + Adj.

transferência nuclear não-autóloga (s.f.) $\mathrm{S}+\mathrm{Adj}$. + Adj.

\subsubsection{6. $S$ (sigla) + Adj.}

DNA antigo (s.m.) - S(sigla) + Adj.

DNA antisense (s.m.) - S(sigla) + Adj.(estrang.)

DNA biparental (s.m.) - S(sigla) + Adj.

DNA centromérico (s.m.) - S(sigla) + Adj.

DNA circular (s.m.) - S(sigla) + Adj.

DNA complementar (s.m.) - S(sigla) + Adj.

DNA complementar intermediário (s.m.) - S(sigla) + Adj + Adj.

DNA espaçador (s.m.) - S(sigla) + Adj.

DNA exógeno (s.m.) - S(sigla) + Adj.

DNA genômico (s.m.) - S(sigla) + Adj.

DNA genômico nuclear (s.m.) - S(sigla) + Adj. + Adj.

DNA hélice dupla (s.m.) - S(sigla) + SN (S + Adj).

DNA ligase (s.m.) - S(sigla) + Adj.

DNA linear (s.m.) - S(sigla) + Adj.

DNA lixo (s.m.) - S(sigla) + SAdj.

DNA mitocondrial (s.m.) - S(sigla) + Adj.

DNA não-funcional (s.m.) - S(sigla) + Adj.

DNA natural (s.m.) - S(sigla) + Adj.

DNA nu (s.m.) - S(sigla) + Adj.

DNA nuclear (s.m.) - S(sigla) + Adj.

DNA plasmidial (s.m.) - S(sigla) + Adj.

DNA polimerase (s.m.) - S(sigla) + Adj.

DNA polimórfico amplificado aleatoriamente (s.m.) - S(sigla) + Adj. + Adj. + Adv.

DNA recombinante (s.m.) - S(sigla) + Adj.

DNA recombinante (s.m.) - S(sigla) + Adj.

DNA recombinante natural (s.m.) - S(sigla) + Adj. + Adj.

DNA repetitivo (s.m.) - S(sigla) + Adj.

DNA repetitivo não-funcional (s.m.) - S(sigla) + Adj. + Adj.

DNA sintético (s.m.) - S(sigla) + Adj.

DNA transformante (s.m.) - S(sigla) + Adj.

DNA unifilamentar (s.m.) - S(sigla) + Adj.

DNA vetor (s.m.) - S(sigla) + SAdj.

PCR inversa (s.f.) - S(sigla) + Adj.

RNA antisense (s.m.) - S(sigla) + Adj. (estrang.)

RNA interferência (s.m.) - S(sigla) + SAdj.

RNA mensageiro (s.m.) - S(sigla) + Adj.

RNA mensageiro citoplasmático (s.m.) - S(sigla) + Adj. + Adj.

RNA natural (s.m.) - S(sigla) + Adj.

RNA polimerase (s.m.) - S(sigla) + SAdj.

RNA recombinante (s.m.) - S(sigla) + Adj.

RNA replicase (s.m.) - S(sigla) + SAdj.

RNA ribossômico (s.m.) - S(sigla) + Adj.

RNA sintético (s.m.) - S(sigla) + Adj.

RNA transportador (s.m.) - S(sigla) + Adj. 


\subsubsection{S(sigla) + SAdj}

DNA megassatélite (s.m.) - S(sigla) + SAdj DNA microssatélite (s.m.) - S(sigla) + SAdj DNA minissatélite (s.m.) - S(sigla) + SAdj

DNA molde (s.m.) - S(sigla) + SAdj.

DNA satélite (s.m.) - S(sigla) + SAdj.

\subsubsection{8. $S+S P$}

alelo de risco (s.m.) - S + SP

algoritmo de normalização (s.m.) - S + SP

algoritmo de Smith-Waterman (s.m.) - S + SP(epônimo)

alinhamento de seqüência (s.m.) - S + SP

alinhamento de YACs (s.m.) - S + SP(sigla)

análise de deleção (s.f.) - S + SP

análise de Fourier (s.f.) - S + SP(epônimo)

análise de heredograma (s.f.) - S + SP

análise de ligação (s.f.) $-\mathrm{S}+\mathrm{SP}$

análise de mapeamento (s.f.) $-\mathrm{S}+\mathrm{SP}$

análise de seqüência (s.f.) $-\mathrm{S}+\mathrm{SP}$

análise de supressor (s.f.) $-\mathrm{S}+\mathrm{SP}$

anotação de genoma (s.f.) - $\mathrm{S}+\mathrm{SP}$

anotação de seqüência (s.f.) - $\mathrm{S}+\mathrm{SP}$

banco de dados (s.m.) - S + SP

banco de mutante (s.m.) - S + SP

banda de DNA (s.f.) - S + SP(sigla)

biblioteca de código (s.f.) - S + SP

biblioteca de DNA (s.f.) - S + SP(sigla)

biblioteca de DNAc (s.f.) - S + SP(sigla)

biblioteca de expressão (s.f.) - $\mathrm{S}+\mathrm{SP}$

biblioteca de ORESTES (s.f.) - S + SP(sigla)

biologia de sistemas (s.f.) - S + SP

citometria de fluxo (s.f.) - $\mathrm{S}+\mathrm{SP}$

clivagem de restrição (s.f.) $-\mathrm{S}+\mathrm{SP}$

clonagem de rotina (s.f.) - $\mathrm{S}+\mathrm{SP}$

clone by fone (s.m.) - S + SP(estrang.)

clone de DNA (s.m.) - S + SP(sigla)

clone de interesse (s.m.) - S + SP

códon de parada (s.m.) - S(estrang.) + SP

coloração dos cromossomos (s.f.) - S + SP

comparação de pares (s.f.) - S + SP

comparação de seqüências (s.f.) - S + SP

conjunto de treinamento (s.m.) - S + SP

cristalografia de raio $X$ (s.f.) $-\mathrm{S}+\mathrm{SP}$

cromatografia a gás (s.f.) - $\mathrm{S}+\mathrm{SP}$

cromatografia por afinidade (s.f.) $-\mathrm{S}+\mathrm{SP}$

derivado de OGM (s.m.) - S + SP(sigla)

dicionário de códon (s.m.) - S + SP(estrang.)

disposição em tandem (s.f.) - S + SP(latim)

enzima de restrição (s.f.) - $\mathrm{S}+\mathrm{SP}$

espectometria de massa (s.f.) $-\mathrm{S}+\mathrm{SP}$

espectroscopia em massa (s.f.) $-\mathrm{S}+\mathrm{SP}$ 
estrutura de anotação (s.f.) - S + SP

família de genes (s.f.) - S + SP

família de proteína (s.f.) $-\mathrm{S}+\mathrm{SP}$

fase de leitura (s.f.) $-\mathrm{S}+\mathrm{SP}$

fecundação in vitro (s.f.) - S + SP

ferramenta de curadoria (s.f.) $-\mathrm{S}+\mathrm{SP}$

fertilização in vitro (s.f.) - $\mathrm{S}+\mathrm{SP}$

filtragem de repetições (s.f.) - S + SP

fingerprints de DNA (s.m.) - S(estrang.) + SP(sigla)

fluxo de distribuição (s.m.) - S + SP

freqüência de recombinantes (s.f.) - $\mathrm{S}+\mathrm{SP}$

gel de agarose (s.m.) - S + SP

gel de eletroforese (s.m.) - S + SP

gene de interesse (s.m.) - $\mathrm{S}+\mathrm{SP}$

gene de manutenção (s.m.) - S + SP

genética das populações (s.f.) - $\mathrm{S}+\mathrm{SP}$

hibridização de Southern ${ }^{24}$ (s.f.) - S + SP(epônimo)

hibridização in situ (s.f.) - S + SP

homologia de seqüência (s.f.) $-\mathrm{S}+\mathrm{SP}$

identidade de seqüência (s.f.) $-\mathrm{S}+\mathrm{SP}$

identificação de motivos (s.f.) $-\mathrm{S}+\mathrm{SP}$

imagem de arranjo (s.f.) $-\mathrm{S}+\mathrm{SP}$

interface de usuário (s.f.) - $(\mathrm{S}+\mathrm{SP})$

junção de vizinhos (s.f.) - S + SP)

Lei da Biossegurança (s.f.) - S + SP

linguagem de script (s.f.) - S $+\mathrm{SP}$ (estrang.)

localizador de gene (s.m.) - S + SP

logo de seqüência (s.m.) - S + SP

mapa de seqüência (s.f.) - $\mathrm{S}+\mathrm{SP}$

mapeamento de restrição (s.m.) - S + SP

mapeamento de RFLP (s.m.) - S + SP(sigla)

mapeamento físico (s.m.) - $\mathrm{S}+\mathrm{SP}$

marcação in situ (s.f.) - S + SP(latim)

matriz de leitura (s.f.) - $\mathrm{S}+\mathrm{SP}$

matriz de pontuação (s.f.) - $\mathrm{S}+\mathrm{SP}$

matriz de substituição (s.f.) $-\mathrm{S}+\mathrm{SP}$

método da similaridade (s.m.) - S + SP

método de Bellman (s.m.) - S + SP(epônimo)

método de conteúdo (s.m.) - S + SP

método de Sanger (s.m.) - S + SP(epônimo)

mineração de dados (s.f.) $-\mathrm{S}+\mathrm{SP}$

modelagem por homologia (s.f.) $-\mathrm{S}+\mathrm{SP}$

montagem de genoma (s.f.) $-\mathrm{S}+\mathrm{SP}$

mutação de ponto (s.f.) - $\mathrm{S}+\mathrm{SP}$

mutação sem sentido (s.f.) - S + SP

mutagênese in vitro (s.f.) - $\mathrm{S}+\mathrm{SP}$ (latim)

notação de Newick (s.f.) - S + SP(epônimo)

ordenamento por FISH (s.m.) - S + SP(sigla)

padrão de fragmento (s.m.) - S + SP

padrão de seqüência (s.m.) - S + SP

painel de hibridização (s.m.) - S + SP

par de primers (s.m.) - S + SP(estrang.)

perfil de expressão (s.m.) - S + SP

${ }^{24}$ Referência ao biólogo britânico Edwin Southern, o que fez com que outros métodos de transferência fossem batizados com trocadilhos ao nome de Southern: transferência de Western e de Northern, por exemplo. 
perfil de seqüência (s.m.) - S + SP

polimorfismo de comprimento (s.m.) - S + SP

pontuação de alinhamento (s.f.) $-\mathrm{S}+\mathrm{SP}$

potencial de diferenciação (s.m.) - S + SP

predição de genes (s.f.) - S + SP

primer de PCR (s.m.) - S(estrang.) + SP(sigla)

primer de replicação (s.m.) - S(estrang.) + SP

probabilidade de ocorrência (s.f.) - S + SP

proteína de fusão (s.f.) - S + SP

reconhecimento de padrões (s.m.) - S + SP

regra de Chargaff (s.f.) - S + SP(epônimo)

rótulo de seqüência (s.m.) - S + SP

seqüência de consenso (s.f.) $-\mathrm{S}+\mathrm{SP}$

seqüência de nucleotídeos (s.f.) - S + SP

seqüência de sinal (s.f.) - $\mathrm{S}+\mathrm{SP}$

seqüência de transposição (s.f.) - S + SP

seqüenciamento de DNA (s.m.) - S + SP

sintetizador de DNA (s.m.) - S + SP(sigla)

sítio de poliadenilação (s.m.) - S + SP

sítio de splining (s.m.) - S + SP(estrang.)

software de basecalling (s.m.) - S(estrang.) + SP(estrang.)

sonda de DNA (s.f.) - S + SP(sigla)

sonda de DNAc (s.f.) - $\mathrm{S}+\mathrm{SP}$ (sigla)

transdução de sinal (s.f.) - S + SP

transferência de Northern (s.f.) - S + SP(epônimo)

transferência de Southern (s.f.) - S + SP(epônimo)

transferência de Western (s.f.) - S + SP(epônimo)

unidade de mapa (s.f.) - S + SP

vacina de DNA (s.f.) - S + SP(sigla)

vetor de clonagem (s.m.) - S + SP

vetor de expressão (s.m.) - S + SP

vetor de levedura (s.m.) - S + SP

vetor de seqüenciamento (s.m.) - S + SP

vetor de transporte (s.m.) - S + SP

via de sinalização (s.f.) $-\mathrm{S}+\mathrm{SP}$

vírus da vaccínia (s.m.) - S + SP

$$
\text { 4.1.2.9. } S+S P(S+S P)
$$

agrupamento de perfis de expressão (s.m.) - S + SP (S + SP)

algoritmo de comparação de seqüências (s.m.) - S + SP (S + SP)

algoritmo de detecção de estrutura (s.m.) - S + SP (S + SP)

alinhamento de pares de seqüência (s.m.) - S + SP (S + SP)

análise de microarranjo de DNA (s.f.) - $\mathrm{S}+\mathrm{SP}(\mathrm{S}+\mathrm{SP})$

Banco de Célula de Trabalho (s.m.) - S + SP (S + SP)

banco de dados de seqüência (s.m.) - $\mathrm{S}+\mathrm{SP}(\mathrm{S}+\mathrm{SP})$

Bancos de Células de Referência (s.m.) - S + SP (S + SP)

Certificado de Qualidade em Biossegurança (s.m.) - S + SP (S + SP)

comparação de pares de seqüência (s.f.) - S + SP (S + SP)

cromatografia por exclusão de tamanho (s.f.) $-\mathrm{S}+\mathrm{SP}(\mathrm{S}+\mathrm{SP})$

detecção de características no DNA (s.f.) - S + SP(S + SP(sigla))

deteç̧ão de padrão de seqüência (s.f.) - $\mathrm{S}+\mathrm{SP}(\mathrm{S}+\mathrm{SP})$

eletroforese em gel de agarose (s.f.) - $\mathrm{S}+\mathrm{SP}(\mathrm{S}+\mathrm{SP})$

eletroforese em gel de poliacrilamida (s.f.) $-\mathrm{S}+\mathrm{SP}(\mathrm{S}+\mathrm{SP})$

gene de reparo de danos no DNA (s.m.) $-\mathrm{S}+\mathrm{SP}(\mathrm{S}+\mathrm{SP}($ sigla $))$ 
gene de resistência a drogas (s.m.) - S + SP (S + SP)

hibridização in situ com fluorescência (s.f.) - S + SP(latim) (S + SP)

imunização com biblioteca de expressão (s.f.) - S + SP ( S + SP)

mapeamento por híbridos de radiação (s.m.) - S + SP (S + SP)

método da distância entre pares (s.m.) - S + SP (S + SP)

método de reconhecimento de padrões (s.m.) - $\mathrm{S}+\mathrm{SP}(\mathrm{S}+\mathrm{SP})$

microarray em lâmina de vidro (s.m.) - S(estrang.) + SP (S + SP)

ordenamento por fingerprints de clones (s.m.) - S + SP( S(estrang.) $+\mathrm{SP})$

penalidade de abertura de intervalo (s.f.) - $\mathrm{S}+\mathrm{SP}(\mathrm{S}+\mathrm{SP})$

penalidade de extensão de intervalo (s.f.) - S + SP (S + SP

polimorfismo de comprimento de fragmento de restrição (s.m.) - S + SP ( SP + SP)

recursos de informações sobre a Arabidopsis (s.m.) - S + SP ( S + SP(epônimo))

sítio de inicio de transcrição (s.m.) - S + SP (S + SP)

software de modelagem por homologia (s.m.) - S (estrang.) + SP (S + SP)

\subsubsection{0. $S+S P(S+A d j$.}

algoritmo de programação dinâmica (s.m.) - S + SP (S + Adj.)

alinhamento de programação dinâmica (s.m.) - S + SP ( S + Adj.)

analise de seqüência única (s.f.) $-\mathrm{S}+\mathrm{SP}(\mathrm{S}+\mathrm{Adj}$.)

banco de clonagem humana (s.m.) - S + SP (S + Adj.)

banco de dados molecular (s.m.) - S + SP (S + Adj.)

Banco de Dados Protéicos (s.m.) - S + SP (S + Adj.)

banco de dados relacional (s.m.) - S + SP (S + Adj.)

célula de linhagem embrionária (s.f.) - $\mathrm{S}+\mathrm{SP}(\mathrm{S}+\mathrm{Adj}$.)

célula de linhagem germinativa (s.f.) $-\mathrm{S}+\mathrm{SP}(\mathrm{S}+\mathrm{Adj}$.)

clivagem de restrição parcial (s.f.) - $S+S P(S+$ Adj.)

código de barras molecular (s.m.) - S + SP ( $\mathrm{S}+$ Adj.)

códon de parada prematuro (s.m.) $-\mathrm{S}($ estrang. $)+\mathrm{SP}(\mathrm{S}+\mathrm{Adj}$.

cromatografia de troca iônica (s.f.) - S + SP (S + Adj.)

eletroforese em campo invertido (s.f.) - S + SP (S + Adj.)

família de genes codificantes (s.f.) - $\mathrm{S}+\mathrm{SP}$ (S + Adj.)

família de genes dispersos (s.f.) $-\mathrm{S}+\mathrm{SP}(\mathrm{S}+\mathrm{Adj}$.)

família de genes em tandem (s.f.) - $\mathrm{S}+\mathrm{SP}(\mathrm{S}+$ Adj.)

família de genes funcionais (s.f.) $-\mathrm{S}+\mathrm{SP}(\mathrm{S}+\mathrm{Adj}$.)

freqüência de crossing over meiótico (s.f.) - S + SP ( S(estrang.) + Adj.)

gene com expressão diferencial (s.m.) - $\mathrm{S}+\mathrm{SP}$ (S + Adj.)

gene de cópia única (s.m.) - $\mathrm{S}+\mathrm{SP}(\mathrm{S}+\mathrm{Adj}$.)

hibridização de célula somática (s.f.) - $\mathrm{S}+\mathrm{SP}(\mathrm{S}+\mathrm{Adj}$.)

instalação de boot duplo (s.f.) - S + SP (S(estrang.) + Adj.)

ligação a loci conhecidos (s.f.) - S + SP (S + Adj.)

local de divisão íntron-éxon (s.m.) - S + SP (S + SAdj.(estrang.))

loci de caracteres quantitativos (s.m.) - S + SP ( $\mathrm{S}+$ Adj.)

mapa de ligação genética (s.f.) - $\mathrm{S}+\mathrm{SP}(\mathrm{S}+\mathrm{Adj}$.)

mapeamento de baixa resolução (s.m.) - S + SP (S + Adj.)

mapeamento de ligação meiótica (s.m.) - S + SP (S + Adj.)

marcador de sequeiência expressa (s.m.) - S + SP (S + Adj.)

matriz de programação dinâmica (s.f.) - $\mathrm{S}+\mathrm{SP}(\mathrm{S}+$ Adj.)

método de máxima probabilidade $-\mathrm{S}+\mathrm{SP}(\mathrm{S}+$ Adj. $)$

microarranjo de alta densidade (s.m.) - $\mathrm{S}+\mathrm{SP}$ ( $\mathrm{S}+$ Adj.)

modelagem de sistemas dinâmicos (s.f.) - $\mathrm{S}+\mathrm{SP}$ (S + Adj.)

mutação com sentido trocado (s.f.) - S + SP (S + Adj.)

mutação com troca de sentido não-conservativa (s.f.) - S + SP (S + SAdj.)

padrão de bandeamento cromossômico (s.m.) - S + SP (S + Adj.)

padrão de expressão gênica (s.m.) - S + SP (S + Adj.) 
polimorfismo de nucleotídeo único (s.m.) - S + SP (S + Adj.)

probabilidade de ocorrência aleatória (s.f.) $-\mathrm{S}+\mathrm{SP}(\mathrm{S}+$ Adj. $)$

probabilidade de ocorrência significativa (s.f.) - $\mathrm{S}+\mathrm{SP}(\mathrm{S}+$ Adj.)

proteína de funcionamento generalizado (s.f.) - S + SP (S + Adj.)

reação em cadeia polimerase (s.f.) - S + SP (S + Adj.)

seqüência de replicação autônoma (s.f.) - $\mathrm{S}+\mathrm{SP}(\mathrm{S}+\mathrm{Adj}$.)

sonda de DNA sintético (s.f.) - S + SP (S(sigla) + Adj.)

tecnologia do DNA recombinante (s.f.) - S + SP (S + Adj.)

$$
\text { 4.1.2.11. } S+S P(S+S P+A d j .)
$$

alinhamento de pares de seqüência global (s.m.) - S + SP ( S + SP + Adj.)

alinhamento de pares de seqüência local (s.m.) - $\mathrm{S}+\mathrm{SP}(\mathrm{S}+\mathrm{SP}+$ Adj.)

$$
\text { 4.1.2.12. } S+\text { Adj. + SP }
$$

alinhamento múltiplo de seqüências (s.m.) - S + Adj. + SP

Comissão Interna de Biossegurança (s.f.) - S + Adj. + SP

Conselho Nacional de Biossegurança (s.m.) - S + Adj. + SP

cromosomo artificial de bactéria (s.m.) - S + Adj. + SP

cromossomo artificial de levedura (s.m.) - S + Adj. + SP

elemento reguladore a jusante (s.m.) - S + Adj. + SP

elemento reguladore a montante (s.m.) - S + Adj. + SP

Instituto Nacional de Saúde (s.m.) - S + Adj. + SP

mapeamento meiótico por recombinação (s.m.) - S + Adj. + SP

matriz aberta de leitura (s.f.) - S + Adj. + SP

sítio múltiplo de clonagem (s.m.) - S + Adj. + SP

quadro aberto de leitura (s.f.) $-\mathrm{S}+\mathrm{Adj} .+\mathrm{SP}$

seqüenciamento aleatório de clones (s.m.) - S + Adj. + SP

sistema diíbrido de leveduras (s.m.) - S + Adj. + SP

$$
\text { 4.1.2.13. } S+A d j+S P(S+S P)
$$

agrupamento automático de perfis de expressão (s.m.) - S + Adj + SP ( S + SP)

análise serial da expressão do gene (s.f.) - S + Adj + SP (S + SP)

Comissão Nacional de Ética em Pesquisa (s.f.) - S + Adj. + SP (S + SP)

$$
\text { 4.1.2.14. } S+\text { Adj. }+S P(S+\text { Adj. })
$$

célula mononuclear da medula óssea (s.f.) - S + Adj. + SP ( $S+$ Adj.)

célula somática de hibridoma animal (s.f.) - S + Adj. + SP (S +Adj.)

terapia celular com células-tronco embrionárias (s.f.) - S + Adj. + SP (S + Adj)

$$
\text { 4.1.2.15. } S+S P+(S+S P(S+A d j .))
$$

eletroforese em gel de campo pulsado (s.f.) $-\mathrm{S}+\mathrm{SP}+(\mathrm{S}+\mathrm{SP}(\mathrm{S}+\mathrm{Adj})$.

eletroforese em gel de poliacrilamida desnaturante (s.f.) $-\mathrm{S}+\mathrm{SP}+(\mathrm{S}+\mathrm{SP}(\mathrm{S}+\mathrm{Adj})$.

$$
\text { 3.3.2.16. S(composto) }+S P
$$

célula-tronco da epiderme (s.f.) - S(composto) + SP 
célula-tronco de teratoma (s.f.) - S(composto) + SP

\subsubsection{Outras estruturas}

Comissão Técnica Nacional de Biossegurança (s.f.) - S + Adj. + Adj. + SP

Consórcio Internacional de Seqüenciamento do Genoma Humano (s.m.) - S + Adj. + SP (S + SP + Adj)

cromatografia líquida desnaturante de alta resolução (s.f.) - S + Adj + Adj. + SP(S + Adj)

espectometria de massas da ionização da dessorção a laser auxiliada por matriz (s.f.) - S + SP ( S + SP (S + SP) $\mathrm{S}+\mathrm{SP}+\mathrm{SV}+\mathrm{SP}$ )

eletroforese em gel com gradiente de desnaturação (s.f.) - S + SP ( S + SP ( S+ SP)

família de genes funcionais dispersos (s.f.) $-\mathrm{S}+\mathrm{SP}(\mathrm{S}+$ Adj. + Adj. $)$

família de genes funcionais em tandem (s.f.) $-\mathrm{S}+\mathrm{SP}(\mathrm{S}+\mathrm{Adj} .+\mathrm{SP}(\mathrm{latim}))$

gene com padrão complexo de herança (s.m.) - S + SP (S + Adj) + SP

mapa cromossômico de alta resolução (s.f.) $-\mathrm{S}+\mathrm{Adj} .+\mathrm{SP}(\mathrm{S}+\mathrm{Adj}$.)

mapeamento de recombinação de alta resolução (s.m.) - S + SP (S + SP (S + Adj.))

matriz de pontuação especifica da posição (s.f.) $-\mathrm{S}+\mathrm{SP}(\mathrm{S}+\mathrm{Adj}$. $+\mathrm{SP})$

método de seqüênciamento de DNA de Sanger (s.m.) - S + SP (S + SP) + SP (S + SP(epônimo)

método do grupo de pares não ponderados utilizando medias aritméticas (s.m.) - S + SP ( S + SP (S + Adj.) + $\mathrm{SV}+\mathrm{SN}(\mathrm{S}+\mathrm{Adj})$.

microarranjo de oligonucleotídeo gerado por síntese de DNA in situ (s.m.) - S + SP ( S + SV + SP ( S + SP +

$\mathrm{SP})$

modelo de perfil oculto de Markov (s.m.) - S + SP ( S + Adj. + SP(epônimo))

moléculas com elevado potencial terapêutico (s.f.) $-\mathrm{S}+\mathrm{SP}$ (Adj. $+\mathrm{S}+$ Adj.)

número variável de repetições em tandem (s.m.) - S +Adj. + SP + SP(latim)

ordenamento por sítios de seqüência marcada (s.m.) - S + SP (S + SP + Adj.)

polimorfismo conformacional de fita simples (s.m.) - S + Adj + SP (S + Adj.)

polimorfismo de comprimento de seqüências simples (s.m.) - S + SP ( S + SP (S + Adj.)

polimorfismo de nucleotídeo único marcador (s.m.) - S + SP (S + Adj. + Adj.)

reação enzimática em cadeia polimerase (s.f.) $-\mathrm{S}+\mathrm{Adj} .+\mathrm{SP}(\mathrm{S}+\mathrm{SAdj}$.)

reparo dos erros de pareamento do DNA (s.m.) $-\mathrm{S}+\mathrm{SP}(\mathrm{S}+\mathrm{SP}(\mathrm{S}+\mathrm{SP}))$

RT-PCR em tempo real (s.m.) - SN(sigla) + SP ( S + Adj.)

sistema de análise de proteína especialista (s.m.) - S + SP ( S + SP + Adj.)

vetor adenoviral all deleted (s.m.) - S + Adj. + SAdj.(estrang.)

\subsubsection{Composição}

\subsubsection{1. base presa / base livre}

adenovírus (s.m.) - aden(o)- + vírus

alotransplante (s.m.) - alo- + transplante

aminoácido (s.m.) - amin(o)- + ácido

baculovírus (s.m.) - bacul(o)- + vírus

eletroporação (s.f.) - eletr(i/o)- + poração ${ }^{25}$

embriogênese (s.f.) - embrio(n)- + gênese

eurocromatina (s.f.) - eur(o)- + cromatina

farmacocinética (s.f.) - farmac(o)- + cinética

farmacodinâmica (s.f.) - farmac(o)- + dinâmica

farmacogenética (s.f.) - farmac(o)- + genética

${ }^{25}$ Em eletroporação, a base livre "poração" pode ser entendida como um derivado de poro, que formaria o verbo hipotético porar* e então seu derivado em poração. 
farmacogenômica (s.f.) - farmac(o)- + genômica

fitomelhoramento (s.m.) - fit(o)- + melhoramento

heteroátomo (s.m.) - heter(o)- + átomo

heterocromatina (s.f.) - heter(o)- + cromatina

heterodúplice (s.m.) - heter(o)- + dúplice

heterozigose (s.f.) - heter(o)- + zigose

homodúplex (s.m.) - hom(o)- + dúplex

imunofluorescência (s.f.) - imun(i/o)- + fluorescência

imunomodulação (s.f.) - imun(i/o)- + modulação

imunoterapia (s.f.) - imun(i/o)- + terapia

lentivírus (s.m.) - lent- + vírus

nitrocelulose (s.f.) - nitr(i/o)- + celulose

pseudofertilização (s.f.) - pseud(o)- + fertilização

pseudotipagem (s.f.) - pseud(o)- + tipagem

radioimunoensaio (s.m.) - radi(o)- + imun(i/o)- + ensaio

totipotente (adj.) - tótus $+-\mathrm{i}-+$ potente

oncogene (s.m.) - onco- + gene

pseudogene (s.m.) - pseud(o)- + gene

xenotransplante (s.m.) - xen(o)- + transplante

proto-oncogene (s.m.) - prot(o)- + onco- + gene

termociclador (s.m.) - termo- + ciclador

\subsubsection{2. base presa / base presa}

bacmídeo (s.m.) - bac- $+-\mathrm{m}+$-ídeo

bacteriófago (s.m.) - bacteri(o)- + -fago

blastocisto (s.m.) - blast(o)- + -cisto

citometria (s.f.) - cit(o)- + -metria

cladograma (s.m.) - clad(o)- + -grama

cristalografia (s.f.) - cristal(o)- + -grafia

cromossomo (s.m.) - crom(o)- + -somo

eletroforese (s.f.) - eletr(i/o)- + gr. phórésis

embriologia (s.f.) - embrio(n)- + -logia

epistasia (s.f.) - ep(i)- + -stasia

eucarionte (s.m.) - eu- + gr. káruon

filogenia (s.f.) - fil(o)- + -genia

fluóforo (s.m.) - fluo(r)- + -foro

hidrólise (s.f.) - hidr(o)- + -lise

histograma (s.m.) - hist(o)- + -grama

homologia (s.f.) - hom(o)- + -logia

idiograma (s.m.) - idi(o)- + -grama

lipossomo (s.m.) - lip(o)- + -somo

metáfase (s.f.) - met(a)- + -fase

monômero (s.m.) - mon(o)- + -mero

multímero (s.m.) - mult(i)- + -mero

mutagênese $^{26}$ (s.f.) - mut(a)- + -gênese

mutágeno (s.m.) - mut(a)- + -geno

oligômero (s.m.) - olig(o)- + -mero

ortológo (adj./s.m.) - ort(o)- + -logo

palíndromo (s.m.) - pali(n)- e -dromo

parólogo (adj.) - par(a)-/para- + -logo

${ }^{26}$ Atestado pelo Dicionário Houaiss como mutação + -gênese (base livre + base presa) e pelo Dicionário Aurélio como muta-+ -gênese (base presa + base presa). Preferimos adotar, para nossa análise, a classificação trazida pelo Aurélio, por julgarmos mais apropriada. 
polímero (s.m.) - poli- + -mero

polimorfismo (s.m.) - poli- + -morfismo (morf(o)- + -ismo)

procarionte $(\mathrm{adj})$ - pro- + cario- + -onte

protoplasma (s.m.) - prot(o)- + -plasma

prototrófico (s.m.) - prot(o)- + -trófico

ribossomo (s.m.) - ribo- + -somo

telômero (s.m.) - telo- + -mero

\subsubsection{3. base livre / base livre}

célula-suporte (s.f.) $-\mathrm{S}+\mathrm{S}$

célula-tronco (s.f.) $-\mathrm{S}+\mathrm{S}$

célula-filha (s.f.) $-\mathrm{S}+\mathrm{S}$

célula-mãe (s.f.) - $\mathrm{S}+\mathrm{S}$

código-fonte (s.m.) - $\mathrm{S}+\mathrm{S}$

genomotipagem (s.f.) $-\mathrm{S}+\mathrm{S}$ (genoma + tipagem (tipo + -agem))

fago-lambda (s.m.) - $\mathrm{S}+\mathrm{S}$

fago-vetor (s.m.) - S $+\mathrm{S}$

herpes-vírus (s.m.) - $\mathrm{S}+\mathrm{S}$

molécula-vetor (s.f.) $-\mathrm{S}+\mathrm{S}$

organismo-modelo (s.m.) - S + S

plasmídeo-vetor (s.m.) - $\mathrm{S}+\mathrm{S}$

seqüência-sujeito (s.f.) $-\mathrm{S}+\mathrm{S}$

seqüência-alvo (s.f.) $-\mathrm{S}+\mathrm{S}$

vetor-livre (s.m.) - S + Adj

\subsubsection{Sigla}

$\mathrm{C} / \mathrm{C}++$ (s.f.) - linguagem computacional

DNA (s.m.) - ácido desoxirribonucléico / deoxyribonucleic acid

ORESTES (s.m.) - ORF ESTs / Open reading frames EST sequences

$R H$ (s.m.) - rhesus factor

RNA (s.m.) - ácido ribonucléico / ribonucleic acid

\subsubsection{Neologismo semântico}

andar pelo cromossomo (s.m.) - "Estes grandes grupamentos de genes homeóticos foram explorados por David Hogness e Walter Gehring, usando a técnica de "andar no cromossomo" (chromosome walking)". (GENÔMICA, 2004, p. 512)

buraco (s.m.) - "Os buracos (gaps) devem aparecer na seqüência, para facilitar melhores combinações?" (GIBAS, C., JAMBECK, P. 2001, p. 179)

motivo (s.m.) - "Um motivo é uma seqüência de aminoácidos que define uma subestrutura em uma proteína que pode ser relacionada à função ou estabilidade estrutural” (GIBAS, C., JAMBECK, P. 2001, p. 34)

biblioteca (s.f.) - "Uma importante vantagem dessa estratégia é que a divisão seqüencial da bilioteca em subbibliotecas cada vez menores pode conduzir à identificação dos antígenos protetores." (GENÔMICA, 2004, p. 505) 


\subsubsection{Estrangeirismo}

\subsubsection{1. do inglês}

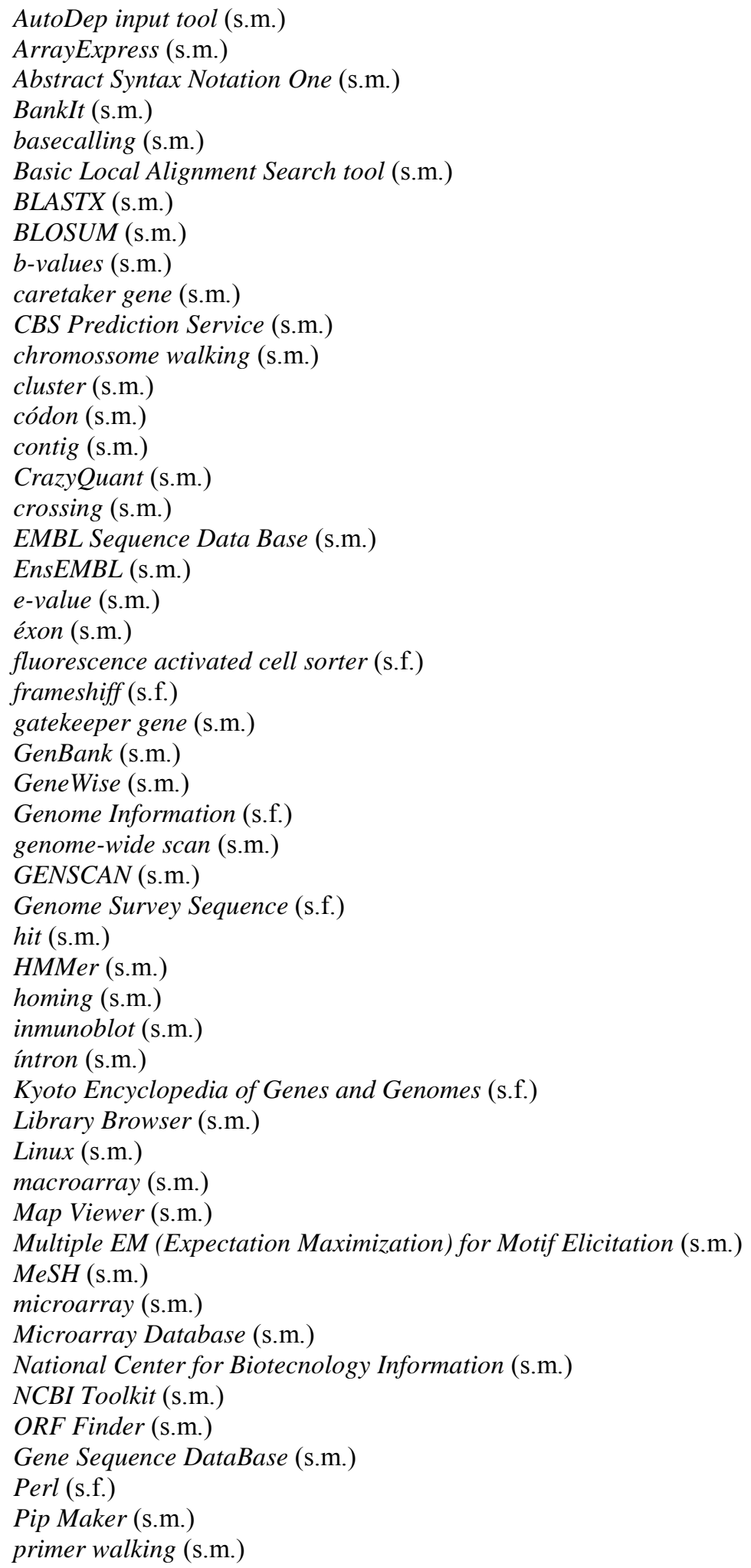


Protein Machine (s.m.)

PubMed (s.m.)

Pyton (s.m.)

regulon (s.m.)

score (s.m.)

Serial Analysis of Gene Expression (s.f.)

SpotFinder (s.m.)

spotter (s.m.)

SSEARCH (s.f.)

Stem Cell Database (s.f.)

Stromal Cell Database (s.f.)

tag (s.m.)

Serial Analysis of Gene Expression (s.f.)

shotgun (s.m.)

The SNP Consortium (s.m.)

transposon (s.m.)

Unix (s.m.)

what is there? (WIT) (s.m.)

4.1.6.1. do francês

cassete (s.m.)

\subsubsection{Outros processos menos produtivos}

\subsubsection{Formação simples}

algoritmo (s.m.)

apoptose (s.f.) (grego): 'apo', «de» + 'ptosis', «queda». célula (s.f.)

clone (s.m.)

colônia (s.f.)

cópia (s.f.)

estroma (s.f.) (latim científico)

estrutura (s.f.)

etiqueta (rótulo) (s.m.)

excisão (s.f.) (latim científico)

expressão (s.f.)

fago (s.m.)

fusão (s.f.)

gene (s.m.)

genética (s.f.)

glioma (s.m.)

identidade (s.f.)

lise (s.f.) (latim científico)

locus (s.m.)

mapa (s.f.)

matriz (s.f.)

molécula (s.f.) (latim científico)

organismo (s.m.)

padrão (s.m.)

perfil (s.m.) 
população (s.f.) (latim)

proteína (s.f.)

programa (s.f.)

seqüência (s.f.)

sítio (s.m.)

sonda (s.f.)

terapia (s.f.)

transdução (s.f.) (latim)

vetor (s.m.)

via (s.f.)

vírus (s.m.)

\title{
4.1.7.2. Eponímia
}

angstron (s.m.)

4.1.7.3. Decalque

automação (s.f.) (do inglês automation)

\subsubsection{Derivação regressiva}

análise (s.f.) (analisar )

consulta (s.f.) (consultar)

transplante (s.m.) (transplantar)

\subsubsection{Redução}

ploidia (s.f.) - redução de haploidia/diploidia

\subsection{Estrutura conceitual dos termos da Genética Molecular}

\author{
Segundo Almeida (2000, p.119):
}

A estrutura conceptual constitui [...] uma representação da realidade do âmbito do domínio que se toma como objeto de estudo. Essa representação procura recolher e organizar todas as ramificações que são próprias do referido domínio, de modo a refletir, em forma de esquema, a realidade da área em questão. 
Cabe destacar que a delimitação de um campo especializado é feita segundo alguns critérios previamente determinados, quais sejam: a) os objetivos do trabalho; b) o públicoalvo que se quer alcançar, e c) o "recorte" da área, o que vai definir a estrutura conceptual (ALMEIDA, 2000, p.119).

Assim, a partir do discutido em 3.1., o recorte que fizemos para a estruturação da área baseou-se no quesito "importância para a disciplina"; desse modo, foram selecionadas ramificações da Genética Molecular que melhor representassem o domínio, no que tange às técnicas e procedimentos mais empregados na ánalise genética, bem como os fundamentos teóricos da disciplina.

Segundo O Pavel: Curso Interativo de Terminologia ${ }^{27}$, a representação de um domínio de especialidade pode ser feita de duas maneiras, de modo que as relações de significação possam ser apresentadas de acordo com suas especificidades:

[...] as relações entre grandes áreas, áreas e subáreas são indicadas num diagrama hierárquico, que é um sistema de representação das relações partitivas (todo-parte), diferentemente dos diagramas arbóreos que representam as relações genéricas (gênero-espécie). Ainda que guardem semelhança entre si, as representaçções gráficas para as relaçoes hierárquicas e para conceitos apresentam considerável diferença de informação. Os diagramas de sistemas conceituais situam os conceitos e suas características dentro das áreas temáticas, enquanto os sistemas de classificação dão uma visão geral dos campos e subcampos.

Sendo assim, dois diagramas conceptuais foram elaborados para a Genética Molecular. No primeiro, um diagrama arbóreo (Fig. 5), apresentamos uma visão geral da área-objeto, subdividida em campos temáticos; no segundo, um diagrama hierárquico (Fig. 6), os termos que compõem cada campo semântico, elencados segundo suas relações conceptuais:

\footnotetext{
${ }^{27}$ Disponível em $<$ http://www.termiumplus.bureaudelatraduction.gc.ca/didacticiel tutorial/portugues/lecon3/page3 22_ 2 p.htm $\underline{1>}$
} 


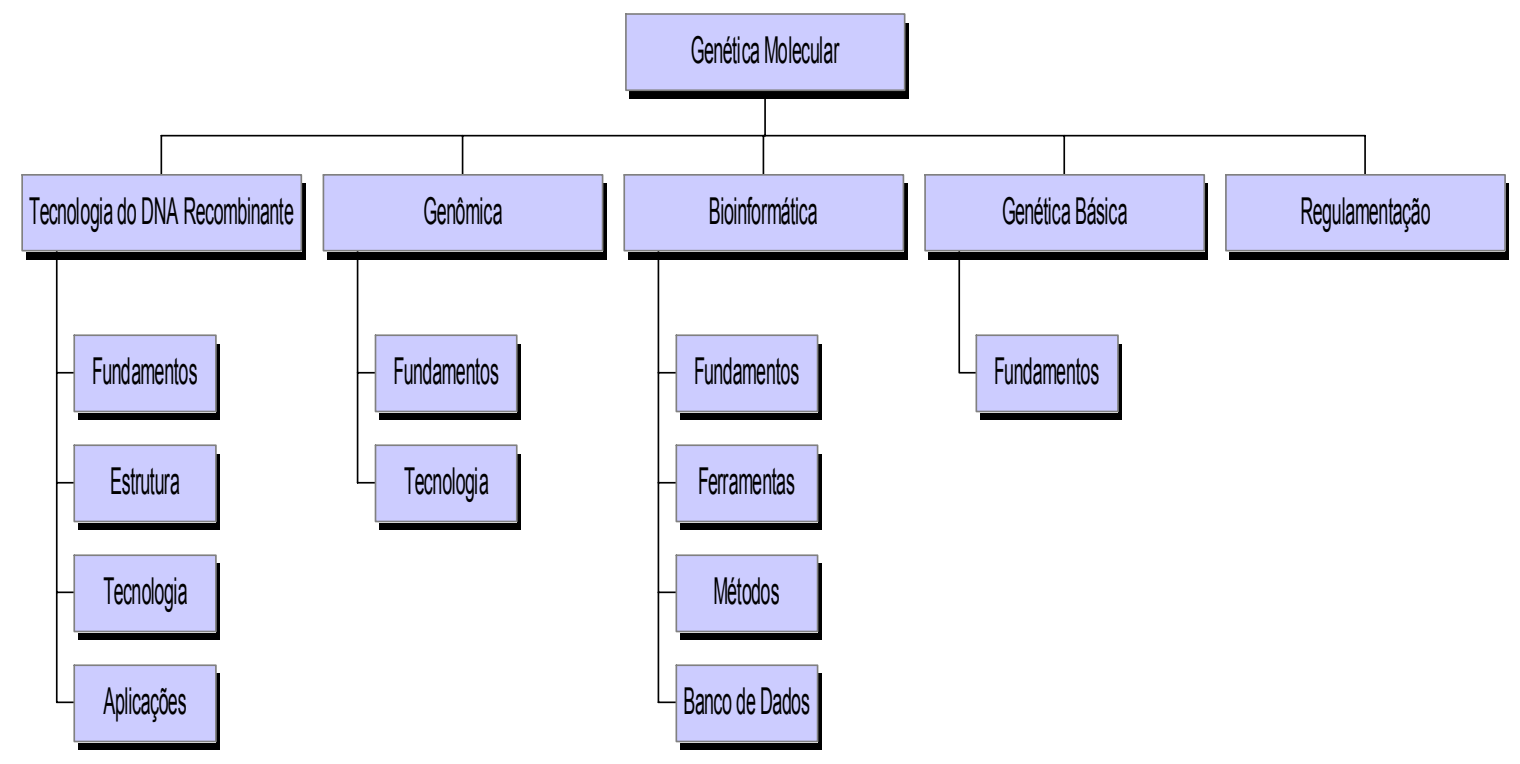

Figura 6. Diagrama arbóreo

Após a elaboração de tal organograma, refletindo a estrutura conceitual da área, os termos recolhidos foram agrupados segundo suas relações de significação. Uma estrutura foi elaborada no FolioViews 4.2, um programa da Microsoft Windows que possibilita a estruturação hierárquica das unidades, estrutura essa que explicita as relações hiperonímicas-hiponímicas dos termos elencados. A seguir, uma amostra (tela) do programa: 


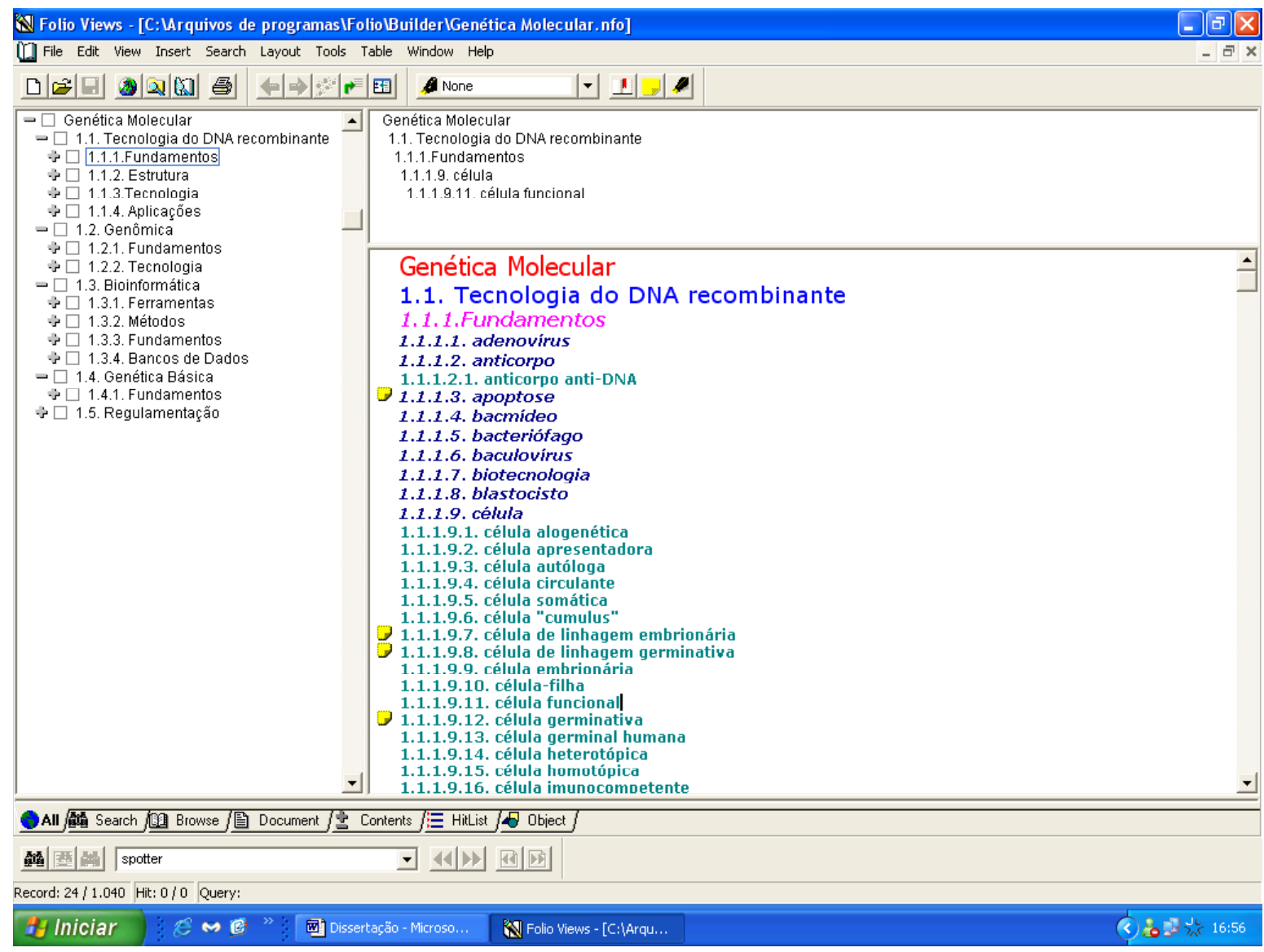

Figura 7. Diagrama hierárquico

Assim, a lista completa dos termos elencados, e agrupados hierarquicamente através do programa FolioViews 4.2., é apresentada em seguida. Cabe esclarecer que a formatação utilizada para a expressão dos diferentes níveis hierárquicos, em número de sete, é a seguinte, segundo informação do próprio programa:

\footnotetext{
<LE:"nivel 1"; FT:Tahoma,SN; PT:16; FC:255,0,0>

$<$ LE:"nivel 2"; FT:Verdana,SN; PT:14; FC:0,0,255>

$<$ LE:"nível 3"; BD+; IT+; FT:Verdana,SN; FC:255,0,255>

<LE:"nivel 4"; BD+; IT+; FT:Verdana,SN; PT:10; FC:0,0,128>

$<$ LE:"nivel 5"; BD+; FT:Verdana,SN; PT:9; FC:0,128,128>

<LE:"nivel 6"; FT:Verdana,SN; PT:10; FC:128,128,0>

$<$ LE:"nivel 7"; FT:Verdana,SN; PT:9; FC:128,0,128>

$<$ LE:"Nível normal"; PT:10>
} 


\title{
Genética Molecular
}

\subsection{Tecnologia do DNA recombinante}

\author{
1.1.1.Fundamentos
}

1.1.1.1. adenovirus

1.1.1.2. anticorpo

1.1.1.2.1. anticorpo antiDNA

1.1.1.3. apoptose

1.1.1.4. bacmideo

1.1.1.5. bacteriófago

1.1.1.6. baculovirus

1.1.1.7. biotecnologia

1.1.1.8. blastocisto

1.1.1.9. célula

1.1.1.9.1. célula alogenética

1.1.1.9.2. célula apresentadora

1.1.1.9.3. célula autóloga

1.1.1.9.4. célula circulante

1.1.1.9.5. célula somática

1.1.1.9.6. célula cumulus

$\checkmark$ 1.1.1.9.7. célula de linhagem embrionária

$\checkmark$ 1.1.1.9.8. célula de linhagem germinativa

1.1.1.9.9. célula embrionária

1.1.1.9.10. célula-filha

1.1.1.9.11. célula funcional

$\checkmark$ 1.1.1.9.12. célula germinativa

1.1.1.9.13. célula germinal humana

1.1.1.9.14. célula heterotópica

1.1.1.9.15. célula homotópica

1.1.1.9.16. célula imunocompetente

$\beta$ 1.1.1.9.17. célula mononuclear da medula óssea

1.1.1.9.18. célula multipotente

1.1.1.9.18.1. célula multipotente alogênica

1.1.1.9.18.2. célula multipotente autóloga

1.1.1.9.19. célula progenitora adulta multipotente

1.1.1.9.20. célula receptora

1.1.1.9.21. célula somática

1.1.1.9.21.1. célula somática de hibridoma animal

1.1.1.9.21.2. célula somática diferenciada

1.1.1.9.22. célula suporte

1.1.1.9.23. célula-mã̃e

1.1.1.9.24. célula-tronco

$\checkmark 1.1,1.9 .24 .1$. célula-tronco adulta

$1,1,1,9.24,2$. célula-tronco autóloga

1.1 .1 .9 .24 .3 . célula-tronco circulante

1.1 .1 .9 .24 .4 . célula-tronco da epiderme

1.1.1.9.24.5. célula-tronco embrionária

1.1.1.9.24.5.1. célula-tronco embrionária diferenciada

$\checkmark$ 1.1.1.9.24.5.2. célula-tronco embrionária de teratoma 1.1.1.9.24.5.3. célula tronco embrionária pluripotente 1.1.1.9.24.5.4. célula-tronco embrionária humana 1.1.1.9.24.5.5. célula-tronco embrionária recombinante

$\checkmark$ 1.1.1.9.24.5.6. célula-tronco embrionária germinativa 1.1.1.9.24.5.7, célula-tronco embrionária indiferenciada 1.1.1.9.24.6. célula-tronco exógena

$\checkmark 1.1 .1 .9 .24 .7$. célula-tronco hematopoiética

1.1.1.9. 24. 7.1. célula-tronco hematopoiética embrionária 1.1 .1 .9 .24 .8 . célula-tronco hepática 
31.1 .1 .9 .24 .9 . célula-tronco mesenquimal

$1,1,1,9,24,10$. celula-tronco neuronal

1.1.1.9.24.11, célula-tronco tecidual

1.1.1.9.24.12. célula-tronco totipotente

$1.1,1,9,24,13$. célula-tronco neural adulta

1.1.1.10. clonagem

1.1.1.10.1. clonagem terapêutica

1.1.1.10.2. clonagem posicional

1.1.1.11. clone

1.1.1.11.1. clone auto-reativo

1.1.1.11.2.clone de DNA

1.1.1.11.3. clone de interesse

1.1.11.4. clone natural

1.1.1.11.5. clone positivo

1.1.1.11.6. clone superposto

1.1.1.12. código de barras molecular

1.1.1.13. código genético

1.1.1.14. códon

1.1.1.14.1. códon traducional

1.1.1.14.2. códon nonsense

1.1.1.14.3. códon de parada

1.1.1.14.3.1. códon de parada prematuro

1.1.1.15. cópia

1.1.1.16. DNA

1.1.1.16.1. DNÁ natural

1.1.1.16.2. DNA recombinante

1.1.1.16.3. DNA sintético

1.1.1.17. dicionário de códon

1.1.1.18. diferenciação

1.1.1.19. embrião humano

1.1.1.20. embriogênese

1.1.1.21. embriologia

1.1.1.22. engenharia genética

1.1.1.23. estroma

1.1.1.24. eucarionte

1.1.1.25. expressão

1.1.1.25.1. expressẫo gênica

1.1.1.26. fuธão

1.1.1.26.1. fusẫo celular

1.1.1.27. gene

1.1.1.27.1. gene desligado

1.1.1.27.2. gene ligado

1.1.1.27.3. gene ativo

1.1.1.27.4. gene candidato

1.1.1.27.4.1. gene-candidato funcional

1.1.1.27.4.2. gene-candidato posicional

1.1.1.27.5. gene clonado

1.1.1.27.5.1. gene clonado mutado

1.1 .1 .27 .5 .2 . gene clonado selvagem

1.1.1.27.6. gene com expressẫo diferencial

1.1.1.27.7. gene com padrẫo complexo de herança

1.1.1.27.8. gene de cópia única

1.1.1.27.9. gene de interesse

$\checkmark$ 1.1.1.27.10. gene de manutenção

1.1.1.27.11.gene de resistência a drogas

1.1.1.27.12. gene estrutural

1.1.1.27.13. gene exógeno 
1.1.1.27.14. gene funcional único

1.1.1.27.15. gene perturbado

1.1.1.27.16. gene programado

1.1.1.27.17. gene repórter

$\checkmark$ 1.1.1.27.18. gene saltador

1.1.1.27.19. gene suicida

1.1.1.27.20. gene viral

1.1.1.28. genética

1.1.1.28.1. genética bacteriana

1.1.1.28.2. genética bioquímica

1.1.1.28.3. genética das populações

1.1.1.28.4. genética forense

1.1.1.28.5. genética reversa

1.1.1.29. hibridização

1.1.1.30. hospedeiro

1.1.1.31. idiograma

1.1.1.32. indutor químico externo

1.1.1.33. infecção viral

1.1.1.34. inserção

1.1.1.34.1. inserção ectópica

1.1.1.35. instabilidade cromossômica

1.1.1.36. intron

1.1.1.37. lentivirus

1.1.1.38. macromolécula

1.1.1.39. molécula

1.1.1.39.1. molécula quimérica

1.1.1.39.2. molécula recombinante

1.1.1.39.3. molécula replicante

1.1.1.39.4. molécula com elevado potencial terapêutico

1.1.1.39.5. molécula-vetor

1.1.1.40. multimero

1.1.1.41. multiplicação celular

1.1.1.42. nucleotideo

1.1.1.42.1. nucleotídeo alternativo

$\checkmark$ 1.1.1.43. número variável de repetiçốes em tandem

1.1.1.44. oncogene

1.1.1.45. óperon ribossomal

1.1.1.46. organismo

1.1.1.46.1. organismo doador

1.1.1.46.2. organismo nấo-patogênico

1.1.1.46.3. organismo projetado

1.1.1.46.4. organismo transgênico

1.1.1.46.5. organismo-modelo

$\checkmark$ 1.1.1.47. organizador nucleolar

1.1.1.48. par de primers

1.1.1.49. plasmideo

1.1.1.49.1. plasmídeo bacteriano

1.1.1.49.2. plasmídeo-vetor

1.1.1.50. ploidia

3 1.1.1.51. pluripotência

1.1.1.52. população

1.1.1.53. potencial de diferenciação

$\checkmark$ 1.1.1.54. primer

1.1.1.54.1. primer de PCR

1.1.1.54.2. primer de replicação

1.1.1.54.3. primer sintético

1.1.1.55. procarionte 
1.1.1.56. produto protéico

1.1.1.57. promotor tardio

1.1.1.58. pronúcleo

1.1.1.59. proporção fenotípica

1.1.1.59.1. proporção fenotípica- padrão

1.1.1.60. proteina

1.1.1.60.1. proteína de fusão

1.1.1.60.2. proteína heteróloga

1.1.1.60.3. proteína análoga

$\checkmark$ 1.1.1.60.4. proteína de funcionamento generalizado

1.1.1.60.5. proteína estrutural

1.1.1.60.6. proteína homóloga

1.1.1.60.6.1. proteína homóloga homeótica

1.1.1.61. proto-oncogene

1.1.1.62. protoplasma

1.1.1.63. prototrófico

1.1.1.64. pseudogene

1.1.1.65. pseudofertilização

1.1.1.66. quimioterápico

1.1.1.67. radioatividade

1.1.1.68. receptor nuclear

1.1.1.69. regulação

1.1.1.69.1. regulação desenvolvimental

1.1.1.69.2. regulação gênica

1.1.1.70. replicação

1.1.1.70.1. replicação autônoma

1.1.1.70.2. replicação prolífica

1.1.1.70.3. replicaçẫo semiconservativa

1.1.1.71. retrotransposon

1.1.1.72. retrovirus

1.1.1.73. $\mathrm{RH}$

1.1.1.74. ribossomo

3 1.1.1.75. RNA

1.1.1.75.1. RNA natural

1.1.1.75.2. RNA recombinante

1.1.1.75.3. RNA sintético

1.1.1.75.4. RNA antisense

1.1.1.75.5. RNA interferência

3 1.1.1.75.6. RNA mensageiro

1.1.1.75.7. RNA citoplasmático

1.1.1.75.8. RNA ribossômico

1.1.1.75.9. RNA polimerase

1.1.1.75.10. RNA replicase

$\checkmark$ 1.1.1.75.11. RNA transportador

1.1.1.76. seqüência

1.1.1.76.1. seqüência de nucleotídeos

$\checkmark$ 1.1.1.76.2. seqüência de replicação autônoma

1.1.1.76.3. seqüência de transposição

1.1.1.76.4. seqüência funcional não-codificante

1.1.1.76.5. seqüência reguladora

1.1.1.76.5.1. seqüência reguladora anterior

1.1 .1 .76 .5 .2 . seqüência reguladora posterior

1.1.1.76.6. seqüência repetitiva

1.1.1.76.6.1. seqüência repetitiva funcional

1.1.1.76.6.2. seqüência repetitiva nã̃o-funcional

1.1.1.76.7. seqüência terminadora

1.1.1.76.8. seqüência-alvo 
1.1.1.77. tecnologia do DNA recombinante

1.1.1.78. tecnologia verde

1.1.1.79. totipotente

1.1.1.80. tradução

1.1.1.81. transcrição

1.1.1.82. transcritase

1.1.1.82.1. transcritase reversa

1.1.1.82.1.1. transcritase reversa viral

1.1.1.83. transdiferenciação

1.1.1.84. transdução

1.1.1.84.1. transdução viral

1.1.1.85. transferência gênica

1.1.1.86. transgene

1.1.1.87. transgênese

1.1.1.88. transgenia

1.1.1.89. transgênico

1.1.1.90. transitor molecular

1.1.1.91. transplante

1.1.1.91.1. transplante alogenético

1.1.1.91.2. transplante autólogo

1.1.1.91.3. alotransplante

1.1.1.91.4. xenotransplante

1.1.1.92. unipotente

1.1.1.93. via de sinalização

1.1.1.94. virus

1.1.1.94.1. vírus adenoassociado

1.1.1.94.2. vírus da vaccínia

1.1.1.94.3. retrovírus

1.1.1.94.4. pró-vírus

1.1.1.94.5. herpesvírus

1.1.2. Estrutura

1.1.2.1. centimorgan

1.1.2.2. disposição

1.1.2.2.1. disposiçẫo cis

1.1.2.2.2. disposiçẫo em tandem

1.1.2.3. DNA

1.1.2.3.1. DNA altamente repetitivo flanqueando o centrômero

1.1.2.3.2. DNA antigo

1.1.2.3.3. DNA antisense

1.1.2.3.4. DNA biparental

1.1.2.3.5. DNA centromérico

1.1.2.3.6. DNA circular

1.1.2.3.7. DNA complementar

1.1.2.3.8. DNA intermediário

1.1.2.3.9. DNA espaçador

1.1.2.3.10. DNA exógeno

1.1.2.3.11. DNA genômico

1.1.2.3.11.1. DNA genômico nuclear

1.1.2.3.12. DNA hélice dupla

1.1.2.3.13. DNA linear

1.1.2.3.14. DNA ligase

1.1.2.3.15. DNA molde

1.1.2.3.16. DNA mitocondrial

1.1.2.3.17. DNA nẫo-funcional

1.1.2.3.18. DNA nu

1.1.2.3.19. DNA nuclear

1.1.2.3.20. DNA plasmidial

$\checkmark$ 1.1.2.3.21. DNA poliligador 
1.1.2.3.22. DNA polimerase

1.1.2.3.23. DNA polimórfico amplificado aleatoriamente

1.1.2.3.24. DNA recombinante

$1.1,2,3,24.1$. DNA recombinante natural

1.1.2.3.25. DNA repetitivo

$1.1 \cdot 2 \cdot 3 \cdot 25.1$. DNA repetitivo nẫo-funcional

1.1.2.3.26. DNA satélite

1.1.2.3.26.1. DNA megassatélite

1.1 .2 .3 .26 .2 . DNA microssatélite

$1 \cdot 1,2 \cdot 3 \cdot 26,3$. DNA minissatélite

1.1.2.3.27. DNA transformante

1.2.2.3.28. DNA total

1.1.2.3.29. DNA unifilamentar

1.1.2.3.30. DNA vetor

3 1.1.2.4. elemento intercalare curto

1.1.2.5. elemento intercalare longo

$\checkmark$ 1.1.2.6. elemento reguladore a jusante

$\checkmark$ 1.1.2.7. elemento reguladore a montante

1.1.2.8. esqueleto molecular

1.1.2.9. estrutura

1.1.2.10. éxon

1.1.2.11. famía de genes

1.1.2.11.1. família de genes codificantes

1.1.2.11.2. família de genes dispersos

1.1.2.11.3. família de genes em tandem

1.1.2.11.4. família de genes funcionais

1.1.2.11.4.1. família de genes funcionais dispersos

1.1 .2 .11 .4 .2 . familia de genes funcionais em tandem

1.1.2.12. helicoidização

1.1.2.13. lipossomo

1.1.2.14. monômero

1.1.2.15. orientação antiparalela

1.1.2.16. palíndromo

1.1.2.17. região reguladora

1.1.2.18. repetição centromérica

1.1.2.19. seqüência

1.1.2.19.1. seqüência de nucleotídeos

1.1.2.19.2. seqüência de replicação autônoma

1.1.2.19.3. seqüência de transposiçẫo

1.1.2.19.4. seqüência funcional

1.1 .2 .19 .4 .1 . seqüencia funcional codificante

1.1.2.19.4.2. seqüência funcional não-codificante

1.1.2.19.5. seqüência reguladora

1.1 .2 .19 .5 .1 . seqüência reguladora posterior

1.1 .2 .19 .5 .2 . seqüencia reguladora anterior

1.1.2.19.6. seqüência repetitiva

1.1 .2 .19 .6 .1 . seqüência repetitiva funcional

1.1.2.19.6.2. seqüência repetitiva não-funcional

1.1.2.19.7. seqüência terminalizadora

1.1.2.19.8. seqüência-alvo

1.1.2.20. terminação repetitiva longa

1.1.2.21. telômero

1.1.3. Tecnologia

1.1.3.1. amplificação

1.1.3.2. análise de ligação

1.1.3.3. análise de mapeamento

$\checkmark$ 1.1.3.4. andar pelo cromossomo 


\subsubsection{5. auto-radiograma}

1.1.3.6. automação

1.1.3.7. auto-replicação

1.1.3.8. banco de clonagem humana

1.1.3.9. banco de dados molecular

1.1.3.10. banco de mutante

1.1.3.11. banda de DNA

1.1.3.12. banda plasmidial

1.1.3.13. biblioteca

1.1.3.13.1. biblioteca de DNAC

1.1.3.13.2. biblioteca de DNA

1.1.3.13.3. biblioteca de expressão

1.1.3.13.4. biblioteca genômica

1.1.3.13.5. biblioteca de ORESTES

1.1.2.14. biobalística

1.1.3.15. cassete

1.1.3.16. centrifugação

1.1.3.17. circularização

1.1.3.18. citometria

1.1.3.18.1. citometria de fluxo

1.1.3.19. clivagem

1.1.3.19.1 clivagem de restriçấo

1.1.3.19.2. clivagem de restrição parcial

1.1.3.20. clonagem

1.1.3.20.1. clonagem shotgun

1.1.3.20.2. clonagem humana

1.1.3. 20.3. clonagem posicional

1.1.3.20.4. clonagem reprodutiva

$1.1 .3 .20,4.1$. clonagem reprodutiva humana

$\beta$ 1.1.3.20.5. clonagem terapêutica

1.1.3.21. clone by fone

1.1.3.22. colônia

1.1.3.23. coloração dos cromossomos

1.1.3.24. contig

1.1.3.25. cosmideo

1.1.3.26. cristalografia

1.1.3.26.1. cristalografia de raio $\mathrm{X}$

1.1.3.27. cromatografia

1.1.3.27.1. cromatografia a gás

1.1.3.27.2. cromatografia líquida desnaturante de alta resoluçấo 1.1.3.27.3. cromatografia de troca iônica

1.1.3.27.4. cromatografia por afinidade

1.1.3.27.5. cromatografia por exclusẫo de tamanho

1.1.3.28. cromossomo artificial

$\checkmark$ 1.1.3.28.1. cromossomo artificial de levedura

1.1.3.28.2. cromossomo artificial humano

$\checkmark$ 1.1.3.28.3. cromossomo artificial de bactéria

1.1.2.29. diafiltração ou filtração tangencial

1.1.3.30. eletroforese

$\beta$ 1.1.3.30.1. eletroforese em campo invertido

$\checkmark$ 1.1.3.30.2. eletroforese em gel com gradiente de desnaturação

$\checkmark$ 1.1.3.30.3. eletroforese em gel de campo pulsado

1.1.3.30.4. eletroforese em gel de agarose

1.1.3.30.5. eletroforese em gel de poliacrilamida

1.1.3.30.6. eletroforese em gel de poliacrilamida desnaturante

1.1.3.31. endonuclease de restrição

1.1.3.32. eletroporação 
1.1.3.33. espectrometria de massa com ionização por electrospray

1.1.3.34. espectometria de massas da ionização da dessorção a laser auxiliada por matriz 1.1.3.35. fago

1.1.3.35.1. fago-lambda

1.1.3.35.2. fago-vetor

1.1.3.35.2.1. fago-vetor unifilamentar

1.1.3.36. fecundação

1.1.3.36.1. fecundação in vitro

1.1.3.36.2. fertilizaçấo in vitro

1.1.3.37. fingerprints de DNA

1.1.3.38. fitomelhoramento

1.1.3.39. fluóforo

$\checkmark$ 1.1.3.40. fluorescence activated cell sorter

1.1.3.41. fluorescência

1.1.3.41.1. imunofluorescência

1.1.3.42. gel bidimensional

1.1.3.43. gel de agarose

1.1.3.44. gel de eletroforese

1.1.3.45. hibridização

1.1.3.45.1. hibridização de célula somática

1.1.3.45.2. hibridização de Southern

1.1.3.45.3. hibridização in situ

$\checkmark$ 1.1.3.45.3.1. hibridização in situ com fluorescência

1.1.3.45.4. hibridizaçẩo unifilamentar

1.1.3.46. hibrido celular

1.1.3.47. hidrólise

1.1.3.48. histograma

1.1.3.49. imunomodulação

1.1.3.50. inmunoblot

1.1.3.51. inoculação

1.1.3.52. ligação

1.1.3.53. ligase

1.1.3.54. lise

1.1.3.55. marcação in situ

1.1.3.56. marcador

1.1.3.56.1. marcador biparental

1.1.3.56.2. marcador diagnóstico

1.1.3.56.3. marcador farmacodinâmico

1.1.3.56.4. marcador haplotípico

1.1.3.56.5. marcador humano

1.1.3.56.6. marcador microssatélite

1.1.3.56.7. marcador molecular

1.1.3.56.8. marcador morfológico

1.1.3.56.9. marcador neutro

1.1.3.56.10. marcador minissatélite

$\checkmark$ 1.1.3.56.11. marcador de seqüência expressa

1.1.3.56.12. marcador toxicológico potencial

1.1.3.56.13. marcador uniparental

1.1.3.57. método de seqüênciamento de DNA de Sanger

1.1.3.58. microarranjo de alta densidade

1.1.3.59. microarray

$\checkmark$ 1.1.3.59.1. microarray em lâmina de vidro

1.1.3.59.2. microarray de oligonucleotídeogerado por síntese de DNA in situ

1.1.3.60. macroarray

1.1.3.61. microscopia eletrônica

1.13.62. mutagênese

1.1.3.62.1. mutagênese in vitro 
1.1.3.62.2. mutagênese sítio-dirigida

1.1.3.63. nitrocelulose

1.1.3.64. nuclease

1.1.3.65. oligonucleotideo sintético

1.1.3.66. plaqueamento

$\checkmark$ 1.1.3.67. perturbação gênica

1.1.3.68. pistola gênica

1.1.3.69. polimerização

1.1.3.70. ponta adesiva

1.1.3.70.1. ponta adesiva complementar

1.1.3.70.2. ponta adesiva unifilamentar

1.1.3.71. ponta coesiva

1.1.3.72. primer walking

1.1.3.73. radioimunoensaio

$\checkmark$ 1.1.3.74. reação em cadeia polimerase

1.1.3.75. reação enzimática em cadeia polimerase

1.1.3.76. PCR inversa

1.1.3.77. RT-PCR em tempo real

1.1.3.78. ressonância nuclear magnética

1.1.3.79. seqüenciamento

1.1.3.79.1. minissequenciamento

1.1.3.79.2. seqüenciamento de DNA

1.1.3.79.3. seqüenciamento didesóxi

1.1.3.79.4. seqüenciamento protéico automatizado

$\checkmark$ 1.1.3.80. Serial Analysis of Gene Expression

1.1.3.81. sintetizador de DNA

1.1.3.82. sistema díbrido de leveduras

1.1.3.83. sonda

1.1.3.83.1. sonda de DNA

1.1.3.83.1.1. sonda de DNA complementar

1.1.3.83.1.2. sonda de DNA sintético

1.1.3.83.2. sonda oligonucleotídica sintética

1.1.3.84. subclonagem

1.1.3.85. tranferência

$\checkmark$ 1.1.3.85.1. transferência de Southern

1.1.3.85.2. transferência de Northern

1.1.3.85.3. transferência nuclear

1.1.3.85.4. transferência nuclear não-autóloga

1.1.3.85.5. transferência de Western

1.1.3.86. transformação

1.1.3.87. ultracentrifugação

1.1.3.88. vetor

1.1.3.88.1. vetor adenoviral

1.1.3.88.2. vetor adenoviral all deleted

1.1.3.88. 3. vetor de clonagem

1.1.3.88.4. vetor de expressã̃o

$\checkmark$ 1.1.3.88.5. vetor de levedura

1.1.3.88.6. vetor de transporte

1.1.3.88.7. vetor recombinante

1.1.3.88.8. vetor de seqüenciamento

1.1.3.88.9. vetor genético

1.1.3.88.10. vetor lentiviral

1.1.3.88.11. vetor livre

1.1.3.88.12. vetor não-viral

1.1.3.88.13. vetor plasmidial

1.1.3.88.14. vetor retroviral

1.1.3.88.15. vetor viral 


\subsubsection{Aplicações}

1.1.4.1. glioma

1.1.4.2. imunoterapia

1.1.4.3. perfil

1.1.4.3.1. perfil farmacodinâmico

1.1.4.3.2. perfil farmacocinético

1.1.4.3.3. perfil genético

1.1.4.4. quimioterápico

1.1.4.5. terapia

1.1.4.5.1. terapia homotópica

1.1.4.5.2. terapia heterotópica

1.1.4.5.3. terapia celular

1.1 .4 .5 .3 .1 , terapia celular heterotópica

1.1.4.5.3.2. terapia celular com células-tronco embrionárias

1.1.4.5.4. terapia gênica

1.1.4.5.4.1. terapia gênica de linhagem germinativa

1.1.4.5.4.2. terapia gênica somática

1.1 .4 .5 .4 .3 . terapia gênica viral

1.1.4.6. tipagem sanguinea

\subsection{Genômica}

1.2.1. Fundamentos

1.2.1.1. caracterização genômica

1.2.1.2. carreador

1.2.1.3. farmacogenômica

1.2.1.4. farmacocinética

1.2.1.5. farmacodinâmica

1.2.1.6. farmacogenética

1.2.1.7. genoma

1.2.1.7.1. genoma doador

1.2.1.7.2. genoma eucariótico

1.2.1.7.3. genoma nuclear

1.2.1.7.4. genoma mitocondrial

1.2.1.7.5. genoma viral

1.2.1.8. genômica

1.2.1.8.1. genômica comparativa

1.2.1.8.2. genômica estrutural

1.2.1.8.3. genômica funcional

1.2.1.9. genotipagem

1.2.1.10. matriz de leitura

$\beta$ 1.2.1.10.1. matriz aberta de leitura

1.2.1.11. megabase

1.2.1.12. proteoma

1.2.1.13. regulon

3 1.2.1.14. unidade de mapa

1.2.1.15. transcriptoma

1.2.2. Tecnologia

1.2.2.1. fosforilação

1.2.2.2. metilação

1.2.2.3. acetilação

1.2.2.4. glicosilação

1.2.2.5. agente imunomodulador

1.2.2.6. bandeamento

1.2.2.7. biblioteca genômica

1.2.2.8. clarificação

1.2.2.9. clonagem 
1.2.2.9.1. clonagem genômica

1.2.2.10. genome-wide scan

1.2.2.11. imunização

1.2.2.11.1. imunização com biblioteca de expressẫo

1.2.2.12. genomatipagem

1.2.2.13. mapa

1.2.2.13.1. mapa cromossômico de alta resolução

1.2.2.13.2. mapa de seqüência

1.2.2.13.3. mapa físico

1.2.2.13.4. mapa genético

1.2.2.13.5. mapa genômico

1.2.2.14. mapeamento

1.2.2.14.1. mapeamento cromossômico

1.2.2.14.2. mapeamento de baixa resoluçã̃o

1.2.2.14.3. mapeamento de ligação meiótica

1.2.2.14.4. mapeamento de recombinação de alta resolução

1.2.2.14.5. mapeamento de restrição

1.2.2.14.6. mapeamento de RFLP

1.2.2.14.7. mapeamento físico

1.2.2.14.8. mapeamento meiótico por recombinação

1.2.2.14.9. mapeamento por híbridos de radiação

1.2.2.15. ordenamento

1.2.2.15.1. ordenamento por fingerprints de clones

1.2.2.15.2. ordenamento por FISH

1.2.2.15.3. ordenamento por sítios de seqüência marcada

1.2.2.16. padrão de bandeamento cromossômico

1.2.2.17. painel de hibridização

3 1.2.2.18. polimorfismo conformacional de fita simples

1.2.2.19. polimorfismo de nucleotídeo único

1.2.2.19.1. polimorfismo de nucleotídeo único marcador

1.2.2.20. pseudotipagem

1.2.2.21. seqüenciamento aleatório de clone

1.2.2.22. transdução

1.2.2.23. translação

1.2.2.24. transfecção

1.2.2.24.1. transfecção retroviral

1.2.2.25. termociclador

1.2.2.26. vacina de DNA

1.3. Bioinformática

1.3.1. Ferramentas

$\beta$ 1.3.1.1. AutoDep input tool

1.3.1.2. algoritmo

1.3.1.2.1. algoritmo de detecção de estrutura

1.3.1.2.2. algoritmo de programaçã̃o dinâmica

1.3.1.2.3. algoritmo Smith-Waterman

1.3.1.2.4. algoritmo de normalizaçẫo

1.3.1.3. ArrayExpress

1.3.1.4. banco de dados de seqüência

1.3.1.5. basecalling

$\checkmark$ 1.3.1.6. Basic Local Alignment Search tool

1.3.1.7. BLASTX

1.3.1.8. BLOSUM

1.3.1.9. b-values

1.3.1.10. $\mathrm{G} / \mathrm{G}++$

1.3.1.11. câmera $C C D$

1.3.1.12. CBS Prediction Service 
1.3.1.13. cladograma

1.3.1.14. CrazyQuant

1.3.1.15. cristalografia por raio $X$

1.3.1.16. EnSEMBL

1.3.1.17. espectroscopia em massa

1.3.1.18. ferramenta de curadoria

1.3.1.19. formato FASTA

1.3.1.20. GeneWise

1.3.1.21. GENSCAN

1.3.1.22. HMMer

1.3.1.23. Library Browser

1.3.1.24. linguagem FORTRAN

1.3.1.25. Linux

1.3.1.26. localizador de gene

1.3.1.27. Map viewer

1.3.1.28. mapa auto-organizável

1.3.1.29. NCBI Toolkit

1.3.1.30. ORF Finder

1.3.1.31. Perl

1.3.1.32. Pip Maker

$\checkmark$ 1.3.1.33. Protein Machine

1.3.1.34. Pyton

1.3.1.35. scanner confocal

1.3.1.36. seqüenciador automático

1.3.1.37. software de basecalling

1.3.1.38. software de modelagem por homologia

1.3.1.39. SpotFinder

1.3.1.40. SSEARCH

1.3.1.41. seqüenciador automático

1.3.1.42. Unix

1.3.1.43. WIT - what is there?

1.3.2. Métodos

1.3.2.1. abordagem dirigida

1.3.2.2. abordagem hit-throughput

1.3.2.3. abordagem shotgun

1.3.2.4. agrupamento de perfis de expressão

1.3.2.4.1. agrupamento automático de perfis de expressão

1.3.2.5. agrupamento hierárquico

1.3.2.6. alinhamento

1.3.2.6.1. alinhamento perfil-seqüência

1.3.2.6.2. alinhamento de pares de seqüência

1.3.2.6.2.1. alinhamento de pares de seqüência global

1.3.2.6.2.2. alinhamento de pares de seqüencia local

1.3.2.6.3. alinhamento de programaçẫo dinâmica

1.3.2.6.4. alinhamento de seqüência

1.3.2.6.5. alinhamento global

1.3.2.6.6. alinhamento local

1.3.2.6.7. alinhamento múltiplo

1.3.2.6.7.1. alinhamento múltiplo de seqüências

1.3.2.6.8. alinhamento par-a-par

1.3.2.6.9. alinhamento perfil-perfil

1.3.2.6.10. alinhamento progressivo

1.3.2.6.11. alinhamento de YAC's

1.3.2.7. análise de Fourier

1.3.2.8. analise de microarray de DNA 
1.3.2.9. análise de seqüência

1.3.2.9.1. análise de seqüência única

1.3.2.10. análise filogenética

1.3.2.11. anotação

1.3.2.11.1. anotação de genoma

1.3.2.11.2. anotação manual

1.3.2.11.3. anotação de seqüência

1.3.2.12. basecalling

1.3.2.13. comparação de pares

1.3.2.13.1. comparaçẫo de pares de seqüência

1.3.2.14. comparação de seqüências

1.3.2.15. conservação

1.3.2.16. cristalografia

1.3.2.17. dimerização

1.3.2.18. disrupção sônica

1.3.2.19. distância Jukes-Gantor

1.3.2.20. encadeamento

1.3.2.21. filtragem de repetiçốes

1.3.2.22. hibridização

1.3.2.23. homing

1.3.2.24. identidade de seqüência

1.3.2.25. identificação de motivos

1.3.2.26. inserção

1.3.2.27. instalação de boot duplo

1.3.2.28. interferência filogenética

$\checkmark$ 1.3.2.29. junção de vizinhos

1.3.2.30. matriz de pontuação especifica da posição

$\checkmark$ 1.3.2.31. Multiple EM (Expectation Maximization) for Motif Elicitation 1.3.2.32. mutagênese sítio-dirigida

1.3.2.33. método da distância entre pares

1.3.2.34. método da similaridade

1.3.2.35. método de Bellman

1.3.2.36. método de conteúdo

1.3.2.37. método de máxima probabilidade

1.3.2.38. método de reconhecimento de padróes

1.3.2.39. método de Sanger

1.3.2.40. método do grupo de pares não-ponderados utilizando médias aritméticas 1.3.2.41. método estatístico

1.3.2.42. mineração de dados

1.3.2.43. modelagem

1.3.2.43.1. modelagem bioquímica

1.3.2.43.2. modelagem de sistemas dinâmicos

1.3.2.43.3. modelagem fisiológica

1.3.2.43.4. modelagem molecular

1.3.2.43.5. modelagem por homologia

1.3.2.44. modelo de perfil oculto de Markov

1.3.2.45. modelo intrinseco

1.3.2.46. modelo probabilístico

1.3.2.47. mutação

1.3.2.47.1. mutaçẫo pontual

1.3.2.47.2. mutação segmentar

1.3.2.48. notação de Newick

1.3.2.49. ORESTES

1.3.2.50. penalidade de abertura de intervalo

1.3.2.51. penalidade de extensão de intervalo 
1.3.2.52. pontuação de alinhamento

1.3.2.53. predição de genes

1.3.2.54. probabilidade de ocorrência

1.3.2.54.1. probabilidade de ocorrência aleatória

1.3.2.54.2. probabilidade de ocorrência significativa

1.3.2.55. programação dinâmica

1.3.2.56. quadro aberto de leitura

1.3.2.57. reconhecimento de padrốes

1.3.2.58. recurso microbiano abrangente

1.3.2.59. regra de Chargaff

1.3.2.60. remoção

1.3.2.61. reparo dos erros de pareamento do DNA

1.3.2.62. replicação

1.3.2.63. resseqüenciamento

1.3.2.64. seqüência parcial

1.3.2.65. shotgun

1.3.2.66. significância estatística

1.3.2.67. similaridade

1.3.2.68. simulação

1.3.2.68.1. simulação bioquímica

1.3.2.68.2. simulação molecular

1.3.2.69. sistema de análise de proteina especialista

1.3.2.70. substituição

1.3.2.71. técnica analítica quantitativa

1.3.2.72. tradução

1.3.2.72.1. tradução reversa

1.3.2.73. transcrição

1.3.2.74. transdução de sinal

1.3.2.75. valor $E$

1.3.3. Fundamentos

1.3.3.1. algoritmo

1.3.3.1.1. algoritmo destruidor

1.3.3.1.2. algoritmo heurístico

1.3.3.1.3. algoritmo ramo-e-limite

1.3.3.1.4. algoritmo de comparação de seqüências

1.3.3.1.5. algoritmo de Smith-Waterman

1.3.3.2. aminoácido

1.3.3.3. angstrom

1.3.3.4. árvore filogenética

1.3.3.5. banco de dados

1.3.3.5.1. banco de dados relacional

1.3.3.6. biblioteca de código

1.3.3.7. bioenergética

1.3.3.8. bioinformática

1.3.3.9. biologia computacional

1.3.3.10. biologia de sistemas

$\checkmark$ 1.3.3.11. buraco

1.3.3.12. casamento

1.3.3.13. cluster

1.3.3.14. código-fonte

1.3.3.15. co-fator

$\checkmark$ 1.3.3.16. consulta

1.3.3.17. computação paralela

1.3.3.18. conjunto de treinamento

1.3.3.19. DNA lixo 
1.3.3.20. e-value

1.3.3.21. estrutura de anotação

1.3.3.22. estrutura primária

1.3.3.23. familia de proteina

1.3.3.24. fase de leitura

3 1.3.3.25. frameshiff

1.3.3.26. filogenia

1.3.3.27. gene ortólogo

1.3.3.28. gene heterólogo

1.3.3.29. heteroátomo

1.3.3.30. hit

1.3.3.31. homologia

$\checkmark$ 1.3.3.31.1. homologia estrutural

1.3.3.31.2. homologia de seqüência

1.3.3.32. identidade

1.3.3.33. imagem de arranjo

1.3.3.34. interação

1.3.3.34.1. interaçẫo interatômica

1.3.3.34.2. interação intermolecular

1.3.3.35. interface de usuário

1.3.3.36. linguagem de script

1.3.3.37. local de divisão intron-exon

1.3.3.38. logo de seqüência

1.3.3.39. mapa de ligação genética

1.3.3.40. matriz

1.3.3.40.1. matriz de pontuação

1.3.3.40.2. matriz de substituição

1.3.3.40.3. matriz de programação dinâmica

1.3.3.41. minisseqüência

1.3.3.42. monômero

1.3.3.43. montagem de genoma

1.3.3.44. motivo

1.3.3.44.1. motivo conservado

1.3.3.45. oligômero

1.3.3.46. ortológo

1.3.3.47. padrão

1.3.3.47.1. padrẫo de expressẫo gênica

1.3.3.47.2. padrẫo de fragmento

1.3.3.47.3. padrẫo de seqüência

1.3.3.47.4. padrẫo flexível

1.3.3.48. parólogo

1.3.3.49. perfil

1.3.3.49.1. perfil de expressã̃o

1.3.3.49.2. perfil de seqüência

1.3.3.50. polímero

$\checkmark$ 1.3.3.51. ponto isoelétrico

1.3.3.52. programa

1.3.3.53. promotor

1.3.3.54. proteômica

1.3.3.55. rede gênica

1.3.3.56. região acentuadora

1.3.3.57. região controladora

1.3.3.58. região regulatória

1.3.3.59. região promotora

$\checkmark$ 1.3.3.60. rótulo

1.3.3.60.1. rótulo de seqüência 


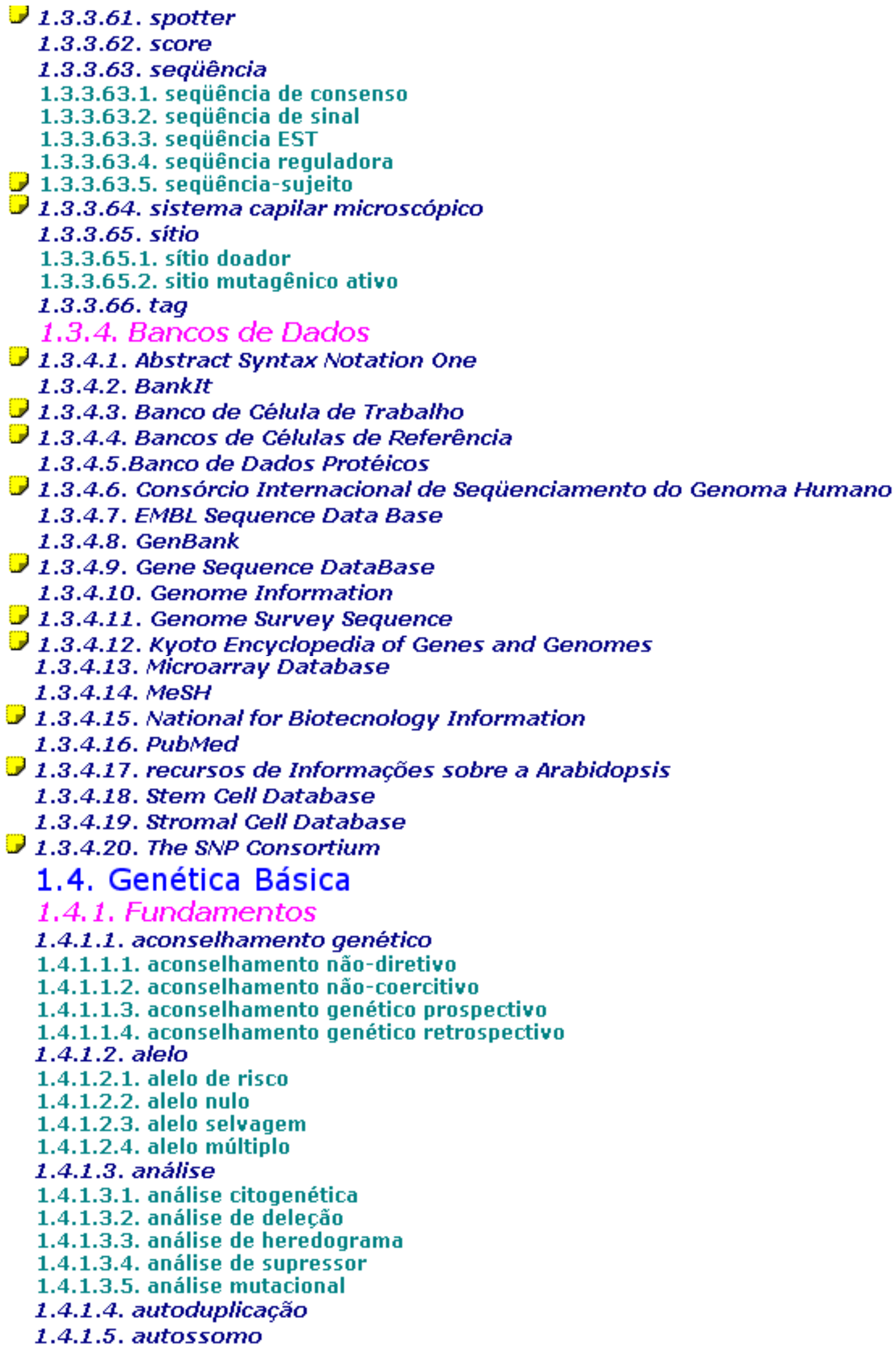




\subsubsection{6. biomolécula}

$\checkmark$ 1.4.1.7. compatibilidade genética

1.4.1.8. complementação funcional

1.4.1.9. conjugação

1.4.1.10. cromossomo

1.4.1.10.1. cromossomo homólogo

1.4.1.10.2. cromossomo politênico

1.4.1.10.3. cromossomo sexual

1.4.1.11. crossing

1.4.1.12. de novo

1.4.1.13. deleção

1.4.1.14. dimorfismo

1.4.1.15. dissecção genética

1.4.1.16. diversidade genética

1.4.1.17. duplicação cromossômica

1.4.1.18. elemento genético móvel

1.4.1.19. epistasia

1.4.1.20. eurocromatina

1.4.1.21. evolução gênica

1.4.1.22. excisăo

1.4.1.23. fita anti-senso

1.4.1.24. fita-senso

1.4.1.25. filtros politênicos

1.4.1.26. luxo de distribuição

1.4.1.27. freqüência de crossing over meiótico

1.4.1.28. freqüência de recombinantes

1.4.1.29. gene

1.4.1.29.1. caretaker gene

1.4.1.29.2. gatekeeper gene

1.4.1.29.3. gene associado

1.4.1.29.4. gene ativador

1.4.1.29.5. gene co-regulador

1.4.1.29.6. gene regulador

1.4.1.29.7. gene desligado

1.4.1.29.8. gene ligado

1.4.1.29.9. gene ativo

1.4.1.29.10 gene-candidato

1.4.1.29.11. gene clonado

1.4.1.29.11.1. gene clonado mutado

1.4.1.29.11.2. gene clonado selvagem

1.4.1.29.12. gene com expressão diferencial

1.4.1.29.13. gene com padrẫo complexo de herança

1.4.1.29.14. gene de cópia única

1.4.1.29.15. gene de interesse

1.4.1.29.16. gene de reparo de danos no DNA

1.4.1.29.17. gene de resistência a drogas

1.4.1.29.18. gene deletério

1.4.1.29.19. gene estrutural

1.4.1.29.20. gene essencial

1.4.1.29.21. gene exógeno

1.4.1.29.22. gene funcional único

1.4.1.29.23. gene nẫo-essencial

1.4.1.29.24. gene perturbado

1.4.1.29.25. gene programado

1.4.1.29.26. gene repressor

1.4.1.29.27. gene saltador

1.4.1.29.28. gene viral 
1.4.1.30. genética reversa

1.4.1.31. herança monogênica

1.4.1.32. heterocárion binucleado

1.4.1.33. heterocromatina

1.4.1.34. heterodúplice

1.4.1.35. heterozigose

1.4.1.36. homodúplex

1.4.1.37. isolamento gênico

1.4.1.38. junção comunicante

1.4.1.39. ligação a loci conhecidos

1.4.1.40. linhagem

1.4.1.40.1. Iinhagem celular

1.4.1.40.2. linhagem específica

1.4.1.40.3. linhagem mutante

1.4.1.40.3.1. linhagem mutante auxotrófica

1.4.1.41. lise

1.4.1.42. lócus

1.4.1.42.1. Ioci de caracteres quantitativos

1.4.1.42.2. Ioci heterozigoto

1.4.1.42,2.1. lócus marcador heterozigoto

1.4.1.43. meiose

1.4.1.44. metáfase $I I$

1.4.1.45. mitose

1.4.1.46. mutação

1.4.1.46.1. mutação auxotrófica

1.4.1.46.2. mutação com sentido trocado

1.4.1.46.3. mutaçấo $\mathrm{com}$ troca de sentido nẫo-conservativa

1.4.1.46.4. mutação conservativa

1.4.1.46.5. mutação de ponto

1.4.1.46.6. mutaçầo deletéría

1.4.1.46.7. mutação dinâmica

1.4.1.46.8. mutação direcionada

1.4.1.46.9. mutação espontânea

1.4.1.46.10. mutaçẫo frame-shift

1.4.1.46.11. mutação induzida

1.4.1.46.12. mutação marcadora

1.4.1.46.13. mutação nula

1.4.1.46.14. mutação patogênica

1.4.1.46.15. mutação polimórfica

1.4.1.46.16. mutação sem sentido

1.4.1.46.17. mutação sinônima

1.4.1.47. mutagênese

1.4.1.48. mutágeno

1.4.1.49. mutante nulo

1.4.1.50. necessidade auxotrófica

1.4.1.51. patrimônio genético

1.4.1.51.1. patrimônio genético natural

1.4.1.52. polimorfismo

1.4.1.52.1. polimorfismo de comprimento

1.4.1.52.1.1. polimorfismo de comprimento de fragmento de restrição

1.4.1.52.1.2. polimorfismo de comprimento de seqüências simples

1.4.1.53. recombinacão

1.4.1.53.1. recombinaçẫo homóloga

1.4.1.53.2. recombinação meiótica

1.4.1.54. replicação

1.4.1.54.1. replicação autônoma

1.4.1.54.2. replicação prolífica 
1.4.1.55. segmento genético

1.4.1.56. segregação

1.4.1.57. sitio de inicio de transcrição

1.4.1.58. sitio de splining

1.4.1.59. sitio de poliadenilação

1.4.1.60. transposon

1.4.1.60.1. transposon endógeno

1.4.1.61. triagem

1.4.1.61.1. triagem genética

1.4.1.62. variante genética

1.4.1.63. via de sinalização

1.4.1.64. via metabólica

1.4.1.65. via regulatória

1.5. Regulamentação

$\checkmark$ 1.5.1. Certificado de Qualidade em Biossegurança

$\checkmark$ 1.5.2. Comissão Interna de Biossegurança

1.5.3. Comissão Técnica Nacional de Biossegurança

$\checkmark$ 1.5.4. Conselho Nacional de Biossegurança

1.5.5. Comissão Nacional de Ética em Pesquisa

1.5.6. derivado de OGM

1.5.7. Lei da Biossegurança

1.5.8. Comissão Nacional de Ética em Pesquisa

1.5.9. Instituto Nacional de Saúde

1.1.10. bioética 


\section{Considerações finais}

O objetivo primeiro deste trabalho está centrado na facilitação da comunicação especializada, e a Terminologia vem, por meio do estudo dessas linguagens de especialidade e de seu vocabulário, criar um meio de comunicação mais eficiente e preciso, e que permita o intercâmbio tecnológico entre os diversos segmentos de estudos em Genética Molecular brasileiros e de grandes centros de pesquisa sediados no exterior. Deve-se enfatizar que é por meio dessas linguagens que os profissionais divulgam seus conhecimentos e sua cientificidade - e que, por sua vez, são adquiridos por tantos outros.

Com tal intuito, então, o presente trabalho objetivou a descrição, organização e sistematização dessa terminologia, gerando subsídios para a futura elaboração de um dicionário da referida área.

Para tal empreendimento, foram necessárias teorias lingüísticas capazes de dar conta dos fenômenos que permeiam dita análise, sobretudo relativas à morfologia e à semântica.

De acordo com Kocourek (1991, p.110), os formantes constituem um meio eficaz de precisão e sistematização em Terminologia. Precisão no sentido de especificar o sentido/conceito destes elementos e também dos termos que os agregam à sua formação, e sistematização, visando ao uso harmônico em situação de comunicação especializada.

Porém, de acordo com Sager (1999, p. 93 - 94), cada sistema de classificação determina o tipo de processo de formação de palavras necessário para expressar-se, bem como a função que desempenha cada processo e elemento, sendo que diferentes áreas possuem necessidades individuais [tradução nossa]. Está neste fato a justificativa da análise conformacional realizada para a pesquisa: descobrir a que mecanismos lingüísticos recorre a Genética Molecular para expressar seus conceitos.

Dentre os diversos processos que ocorreram, destacamos algumas particularidades. Elementos não originalmente designados como prefixos ou sufixos, mas como elementos de composição, tornam-se altamente produtivos não só na denominação de áreas de especialidade, mas também para a criação lexical da língua geral, sendo assim classificados como prefixos e sufixos lato sensu. É o caso de bio- e -oma, por exemplo.

Elementos da língua geral, como os sufixos -agem, -ção, e -mento e os prefixos ree trans-, são também bastante empregados na conformação do vocabulário da Genética Molecular. 
De acordo com Kocourek (1991, p.110), os sufixos específicos característicos de domínios particulares são, seguramente, utilizados para representar seu domínio de conhecimento; porém, as terminologias recorrem a um inventário comum de formantes sufixais, o que o Autor chama sufixos preferidos, e estes são, essencialmente, aqueles designativos de ação, qualidade e estado. Para Kocourek (1991, p.110):

Les suffixes spécifiques, caractéristiques des domaines individuels, étaient -ose et -ine/-ïne em médicine, -ique en physique, et -um et -é en chimie. Ces donnés semblent confirmer que les trois domaines, tout em ayant chacun des suffixes spécifiques, moins fréquents dans d'autres domaines, recourent à un inventaire commun assez étendu de suffixes préférés, parmi lesquels dominent les suffixes des noms d'action, de qualité et d'état.

Já em relação aos prefixos, dentre os não especificamente caracterizadores de domínios de especialidade, pode-se dizer que são convenientemente escolhidos pelas distintas áreas para representar seus conceitos, sendo que cada qual recorre a um ou outro formante em particular - diferentemente do que ocorre com os sufixos de inventário comum, que tendem a ser recorrentes para áreas distintas.

Um outro fato, comprovado pela análise, baseia-se na questão da produtividade de alguns tipos de formantes para as terminologias. Segundo Cabré, unidades compostas por formantes cultos e por formações sintagmáticas apresentam rendimento bastante elevado em Terminologia, em contraponto à Lexicografia. De fato, nas composições, as formações base presa + base livre e base presa + base presa são constituídas, quase em sua totalidade, por formantes greco-latinos. Já as formações sintagmáticas são, de longe, as mais fecundas, totalizando $69 \%$ das formações.

Como esperado, os estrangeirismos, sobretudo os de língua inglesa, também aparecem em grande número, representando 7,3\% das formações. Quando menciono "esperado", refiro-me ao berço das pesquisas em Genética, além do elevado potencial tecnológico e de pesquisadores que apresentam os países de língua inglesa.

Todos esses traços morfológicos, explicitados através dos formantes ou dos processos de formação lexical constitutivos dessa terminologia, são recorrentes em termos alocados num campo semântico específico, o que comprova a relevância das informações morfológicas para a categorização semântica. 
Além disso, no processo de elaboração de definições terminológicas, essas informações serão de extrema importância, uma vez que fornecem indícios para a adequada escolha de uma tipologia definitória, empregada para grande parte dos termos de um mesmo campo semântico.

O que se pode depreender de toda essa análise é que a descrição dos processos de formação das unidades terminológicas, seguida da análise de seu funcionamento em situação e ambiente especializados, é de grande valia para o avanço dos estudos em Terminologia. Isso porque uma análise lingüística que dê relevo a questões morfossintáticas e semânticas permite uma mais profunda descrição do modus operandi de um sistema lingüístico, fundamental para expressar as ciências e técnicas, mas também para a renovação do léxico geral. Além disso, permite verificar o nível de conhecimento técnicocientífico adquirido pelo País - já que o uso da língua vernácula para expressar uma disciplina acaba por refletir o desenvolvimento da pesquisa e da tecnologia obtida por uma determinada área do conhecimento.

O processo de identificação e seleção de termos também levantou alguns questionamentos. De posse de materiais autênticos, e pré-definidos os campos conceptuais que abrangeriam essa pesquisa, quais eram os termos específicos daqueles domínios eleitos, e quais tangenciavam outras áreas da Genética?

O esclarecimento foi possível somente com o auxílio do especialista na área-objeto, quem descartou termos não-pertinentes. Porém, um não-especialista, em posse dos mesmos textos de onde foram retiradas tais unidades, saberia fazer a mesma diferenciação? Teria problemas de entendimento daquele texto, devido ao teor terminológico ali presente?

Esse ínterim abre uma discussão conflituosa: se a Terminologia utiliza-se dos textos técnico-científicos para formar o seu corpus de pesquisa, local onde estão as unidades terminológicas in vivo, relacionando-se e construindo-se, então, como delimitar quais unidades são pertinentes e quais não são, haja vista a Genética Molecular ser uma subárea da Genética?

Essa questão foi amplamente discutida em ocasião da Qualificação de Mestrado, quando abordado o tema "descarte de termos não-pertinentes". Quais foram os critérios de descarte de termos, e por que foram descartados, uma vez que formam parte de material escrito por especialistas e destinados tanto a especialistas quanto a um público menos 
especializado (aprendizes, por exemplo)? Afinal, não são os textos mesmos os "especialistas" na área-objeto?

Uma solução encontrada para esse conflito foi a inserção do campo "Genética básica" na estrutura de conceitos, haja vista a indispensabilidade dos mesmos para a compreensão dos fatos genéticos explicitados em textos especializados.

Todas essas questões se fazem pertinentes e são, ademais, bastante importantes, se temos em vista a produção de um material terminológico (um dicionário, por exemplo). Esse tipo de preocupação vem a refletir a função que desempenhará tal obra em relação a público-alvo, conteúdo dos verbetes, tipologia da definição, etc.

De modo geral, todas as etapas produzidas e descritas nesta Dissertação servem como um pano de fundo - porém fundamental para a qualidade de uma pesquisa terminológica - para a geração de um material de consulta confiável e condizente com seus propósitos e, sem dúvida, para a disciplina Terminologia. 


\section{Referências}

\subsection{Teorias lingüísticas}

ABNT 00:02.023-003 - Terminologia, Princípios e Métodos: Harmonização de Conceitos (baseada na norma ISO/DIS 860/95)

ALMEIDA, G.M.B. Teoria Comunicativa da Terminologia (TCT): uma aplicação. Araraquara, 2000, vol. I, 290 p.; vol. II, 86 p. Tese (Doutorado em Lingüística e Língua Portuguesa) - Faculdade de Ciências e Letras, Campus de Araraquara, Universidade Estadual Paulista, 2000.

- O percurso da Terminologia: de atividade prática à consolidação de uma disciplina autônoma. Tradterm, São Paulo, v. 9, p. 211-222, 2003.

ALVES, I. M. Um estudo sobre a neologia lexical: os microssistemas prefixais do português contemporâneo. 2000, 379 p. Livre Docência (Livre Docência em Lexicologia e Terminologia). Faculdade de Filosofia, Letras e Ciências Humanas. São Paulo: Universidade de São Paulo, 2000.

. Neologismo - Criação lexical. São Paulo: Ática, 2004.

Associação de Informação Tecnológica (AIT). Disponível em $<$ http://www.ait.pt/index2.htm>. Acesso em 07 de fevereiro de 2007.

AUBERT, F H. Introdução à metodologia da pesquisa terminológica bilíngüe. Cadernos de Terminologia 2. São Paulo: Humanitas Publicações - FFLCH/ USP, 1996.

BARBOSA, M.A. Relações de significação nas unidades lexicais. In: Anais do $\mathbf{1}^{\mathbf{0}}$. Encontro Nacional do GT de Lexicologia, Lexicografia e Terminologia da ANPOLL. UFRJ /Faculdade de Letras, 1997.

BARROS, L. A. Curso básico de terminologia. São Paulo: Editora da Universidade de São Paulo, 2004.

Aspectos epistemológicos e perspectivas científicas da terminologia. Cienc. Cult., abr./jun. 2006, vol.58, no.2, p.22-26.

BOUTIN-QUESNEL, R. et al. Vocabulaire systématique de la terminologie. Québec: Publications du Québec, 1985 (Cahiers de l'Office de la Langue Française). 
CABRÉ, M. T. La terminología - teoría, metodología, aplicaciones (trad. castelhana de Carles Tebé). Barcelona: Editorial Antártida/Empúries, 1993.

La terminología: representación y comunicación - elementos para una teoría de base comunicativa y otros artículos. Barcelona: Institut Universitari de Lingüística Aplicada, 1999.

CARVAlHO, J.G. H. Teoria da linguagem. Coimbra: Atlântida Editora, 1974.

CIASPUCIO, G. E. Textos especializados y terminología. Panorama de las tipologías Barcelona: IULA, 2003 (Sèrie Monografies, 6).

Conselho Regional de Biologia - $3^{\text {a }}$ Região. Disponível em $\leq$ http://www.crbio3.org.br/noticias/index.php?id=1063\&idcategoria=7>. Acesso em $7 \mathrm{de}$ fevereiro de 2007.

COSERIU, E. Principios de semántica estructural. (versión española de Marcos Martínez Hernández, revisada por el autor). 2ª edición, 1ª reimpresión. Madrid: Gredos, 1986.

Pour une sémantique diachronique structurale. Travaux de linguistique et de littérature - II, 1, 1964.

Dicionário de Termos Lingüísticos. Disponível em <http://www.ait.pt/index2.htm>. Acesso em 7 de fevereiro de 2007.

Dicionário Eletrônico Houaiss da Língua Portuguesa. Rio de Janeiro: Editora Objetiva/ Instituto Antonio Houaiss, 2001.

DUBOIS, L. et al. Dicionário de Lingüística. São Paulo: Cultrix, 1989.

DUBUC, R. Manual de terminología. 3a. ed. Chile: Unión Latina/RiL editors, 1999.

FELBER, H. Manuel de terminologie. Paris: UNESCO/Infoterm, 1987.

GAUDIN, F. Socioterminologie - des problèmes sémantiques aux pratiques institutionnelles. Rouen: Publications de l'Université de Rouen n 182, 1993.

GECKLER, H. Semántica estrutural y teoria del campo léxico. Madrid: Editorial Gredos, 1976.

HAENSCH, G., WOLF, L., ETTINGER, S., WERNER, R. La lexicografía - de la lingüística teórica a la lexicografía práctica. Madrid: Editorial Gredos, 1982.

ISO/FDIS 1087-1. Terminology work - Vocabulary. Part 1: Theory and application, 2000.

ISO 704. Terminology work - Principles and methods, 2000. 
IULA. Terminología y comunicación especializada. En Grup IulaTerm. Introducción a la Terminología. Barcelona: IULA. Universidad Pompeu Fabra, 2004a. Disponível em $<$ http://www.iulaonline.org $>$. Acesso em 1 de fevereiro de 2006.

. La unidad terminológica. En Grup IulaTerm. Introducción a la Terminología.

Barcelona: IULA. Universidad Pompeu Fabra, 2004b. Disponível em $<$ http://www.iulaonline.org $>$. Acesso em 1 de fevereiro de 2006 _ _ La Terminología: definición y funciones. En Grup IulaTerm. Introducción a la Terminología. Barcelona: IULA. Universidad Pompeu Fabra, 2004c. Disponível em $<$ http://www.iulaonline.org $>$. Acesso em 1 de fevereiro de 2006.

. La Terminología: historia y organización. En Grup IulaTerm. Introducción a la Terminología. Barcelona: IULA. Universidad Pompeu Fabra, 2004d. Disponível em $<$ http://www.iulaonline.org $>$. Acesso em 1 de fevereiro de 2006.

KEHDI, V. Formação de palavras em português. São Paulo: Ática, 1992.

KRIEGER, M. G. \& FINATTO, M. J. B. Introdução à terminologia: teoria e prática. São Paulo: Contexto, 2004.

KRIEGER, M. G., MACIEL, A. M. B. (orgs.) Temas de Terminologia. Porto Alegre/São Paulo: Universidade-UFRGS/Humanitas-USP, 2001.

KRIEGER, M. G. Terminologia técnico-científica: políticas lingüísticas e Mercosul. Cienc. Cult., Apr./June 2006, vol.58, no.2, p.45-48.

LARA, M. L. G. Novas relações entre Terminologia e Ciência da Informação na perspectiva de um conceito contemporâneo da informação. DataGramaZero - Revista de Ciência da Informação, ago/06, v.7 n.4.

LERAT, P. Las lenguas especializadas (trad. castelhana de Albert Ribas). Barcelona: Editorial Ariel, 1997.

LYONS, J. Semântica. São Paulo: Editorial Presença e Martins Fontes, 1997.

MARONEZE, B. O. Um estudo da nominalização do português do Brasil com base em unidades lexicais neológicas. 2000, 191 p. Dissertação (Mestrado em Filologia e Língua Portuguesa). Faculdade de Filosofia, Letras e Ciências Humanas. São Paulo: Universidade de São Paulo, 2006.

Novo Dicionário Aurélio Eletrônico versão 5.0. São Paulo: Editora Positivo, 2004. 
O Pavel: Curso Interativo de Terminologia. Ministério de obras públicas e serviços governamentais do Canadá.

Disponível em $<$ http://www.termiumplus.bureaudelatraduction.gc.ca/didacticiel_tutorial/portugues/lecon1/ indexe_p.html>. Acesso em 07 de fevereiro de 2007.

PAVEL, S. \& NOLET, D. Manual de terminologia (trad. port. de Enilde Faulstich). Canadá, 2002.

RIO-TORTO, G. M. Morfologia derivacional. Teoria e aplicação ao português. Porto: Porto Editora, 1998.

ROCHA, L. C. A Estruturas morfológicas do português. Belo Horizonte: Ed. UFMG, 1998.

RONDEAU, G. Introduction à la terminologie. Québec: Gaëtan Morin, 1984.

SAGER, J. C. A practical course in terminology processing. Amsterdam/Philadelphia: John Benjamins Publishing Company, 1990.

. Curso práctico sobre el procesamiento de la terminología. Madrid: Fundación G.S. Ruipérez, 1993.

SANDMANN, A J. Formação de palavras no português brasileiro contemporâneo. Curitiba: Scientia et Labor / São Paulo: Ícone, 1989. Morfologia lexical. São Paulo: Contexto, 1991.

TEMMERMAN, R. Towards new ways of terminology description. The sociocognitive approach. Amsterdam/Philadelphia: John Benjamins Publishing Company, 2000.

WÜSTER, E. Introducción a la teoría general de la terminología y a la lexicografía terminológica (responsable de la edición: M. Teresa Cabré) Barcelona: Institut Universitari de Lingüística Aplicada/Universitat Pompeu Fabra, 2003. 


\subsection{Obras especializadas}

Conselho de Informações sobre biotecnologia - CIB. Glossário disponível em $<$ http://www.cib.org.br> . Acesso em 7 de fevreiro de 2007.

Genômica. Organização editorial Luís Mir. São Paulo: Atheneu, 2004.

GRIFFITHS, AS.F. et al. Genética moderna. Rio de Janeiro: Guanabara Koogan, 2001. GIBAS, C., JAMBECK, P. Desenvolvendo Bioinformática: ferramentas de software para aplicações em biologia. Revisão técnica Antônio Basílio de Miranda; tradução Cristina de Amorim Machado; tradução Milarepa Ltda. Rio de Janeiro: Campos, 2001. MINISTÉRIO DA AGRICULTURA, PECUÁRIA E ABASTECIMENTO. Empresa Brasileira de Pesquisa Agropecuária. Embrapa Pecuária Sudeste. Biologia molecular aplicada à produção animal. Brasília, DF: Embrapa Informação Tecnológica, 2001. Revista Pesquisa Fapesp - Ciência e Tecnologia no Brasil. Edições de jan.05 a jan.07. 